\title{
SIXTY-EIGHT PREVIOUSLY UNCOLLECTED REVIEWS OF WALT WHITMAN
}

\author{
Brett Barney, Amanda Gailey, Ted Genoways, \\ Charles Green, Heather Morton, \\ Kenneth M. Price, Yelizaveta Renfro
}

The STORY OF WALT WhitMAN's RECEPTION HISTORY grows more fascinating as additional documents gradually come to light. We have listed here all reviews identified since the publication of Walt Whitman: The Contemporary Reviews (1996), edited by Kenneth M. Price, including a handful that have been posted on the Walt Whitman Archive in the meantime. In the following pages, we reproduce in full or in part those reviews that seem to us most illuminating. (All of the listed new reviews will be made available in their entirety on the Whitman Archive shortly after publication in the Walt Whitman Quarterly Review.) The reviews collected here span the entire range of Whitman's writing career, from his temperance novel Franklin Evans (1842) to the so-called deathbed edition of Leaves of Grass (1891-1892), and they address every edition of Leaves as well as "A Child's Reminiscence," As a Strong Bird on Pinions Free, Two Rivulets, Memoranda During the War, November Boughs, Specimen Days \& Collect, Good-Bye My Fancy, William Michael Rossetti's 1868 British edition (Poems by Walt Whitman), and Ernest Rhys's 1886 British edition (Leaves of Grass: The Poems of Walt Whitman). These reviews also represent the views of critics on both sides of the Atlantic (and include Irish and Scottish perspectives).

Whitman's long-term critical reception has its roots in the reviews that were published during his lifetime. Many of the same ideas and themes that emerged in other previously collected contemporary reviews - as well as in the critical debates that continued after Whitman's death-are evident in the reviews collected here. For example, many of the American reviews tended to take an extreme view, either proclaiming Whitman to be the American Homer or Shakespeare or condemning him for being obscene and vulgar. In an early 1860 review, "Umos" unequivocally declares that Whitman's work is not poetry: "My private opinion expressed to you confidentially is, that Whitman found a lot of dictionary-pi going on at auction, bought it for a song, employed a Chinese type-setter from the Bible House to set it up in lines of unequal length, and then sold it to you as an original Poem." Reviewers attacked both the form and content of Leaves of Grass. "A more scandalous volume we never saw," declares The Springfield Daily Republican in June of 1860. "It ought to be enough for Walt Whitman, if 
he honestly thinks his book a pure one, to know that the pure in society will shun it, and that it will be sought out and laughed over by lewd women and prurient boys and hoary-headed old lechers,- - to know that this notice of his volume will stir to read it only the dregs of the social and moral world into which it goes."

Two decades later, in 1882, Elmina, in her column "Suggestions and Advice to Mothers," rapturously declares the "innate worth and purity" of Whitman's work. "Take, O mothers, a page of Walt Whitman for your morning prayer, and you will begin the day with strong, pure aspirations, and a heart attuned to all that is good, true and beautiful - all that is vigorous, natural and elevating," she writes, concluding, "Grander and purer than all Bibles-a book that shall make lovely women and stalwart men, and sweet, happy, healthful babes." This radically different view does not, however, indicate a general shift in reviewers' responses to Whitman. In the same year, The Atlantic Monthly finds Whitman breaking "one of the deepest and finest of natural laws; and instead of making the body sacred, he despoils it of the sacredness which mankind now generally accords to it. He degrades body and soul by a brutish wallowing in animal matter as animal matter, deprived of its spiritual attributes."

Extreme statements are characteristic of the reviews spanning Whitman's entire poetic career. Many reviewers saw him as a trailblazing visionary whose work would be truly appreciated only by future generations. In 1881, The Springfield Daily Republican placed Whitman in the company of two other contemporary visionaries: "John Brown, Abraham Lincoln and Walt Whitman,-men unlike each other and unlike all others." It went on to praise "Whitman's teeming and unharvested imagination." That same year, the Saint Paul and Minneapolis Pioneer Press also identified Whitman's visionary quality: "He is, indeed a poet who sees far and keenly; and no doubt the reader of the future will believe it still more than we."

Many reviewers connected Whitman's outlook with his deep-rooted sense of being an American poet. In 1881, the Boston Globe proclaimed: "Walt Whitman has written the drama-it may be almost called the history - of the first century of American civilization." A month later, The Worthington Advance explored the idea of Whitman as an American poet at greater length:

He has laid the foundations, started the idea, of a genuine Democratic, New World, thoroughly American literature, and after him will come some great poet who will be the Shakspeare to this Chaucer. ... Longfellow, Bryant, Whittier, Lowell and the rest will be remembered in the Cyclopedias as poets who did creditable work in English literature, but Whitman and his class will loom over the future as the founders and makers of an American literature. 
The linking of Whitman with a distinctively American poetry and vision and with an idea of democracy that often verges on the spiritual are ideas that would shape scholarship for decades after Whitman's death.

A number of the reviews presented here exhibit a more moderate, mixed reaction to Whitman's work. Some reviewers found flashes of brilliance amongst the poet's otherwise incoherent and chaotic work. In May of 1860, for example, the Albion discovered "a slender thread of truth and purity" in Leaves of Grass:

As to these 'Leaves of Grass,' nine-tenths of them are covered with words that have no more meaning, coherency, or perceptible purpose than the columns in a spellingbook; while the indecency - an indecency not born of prurience, but of the absolute refusal to recognize such a distinction as decent and indecent-is monstrous beyond precedent, and were it not before our eyes, beyond belief. Yet for the one-tenth that we have excepted we shall keep the book, and read it, not without a strange interest in the man who could draw such a slender thread of truth and purity through such a confused mass of folly, feculence, and falsehood.

Three months later, the National Quarterly Review reiterated this mixed appraisal of Whitman: "The author seems to exult in being as indecent, obscene, and profane as possible. This is the more to be regretted, because, in the midst of a great deal of the silliest twaddle, and the most unmeaning bombast, we find thought of rare beauty and striking force, wonderful felicity of expression, and imagery at once boldest and most pleasing." This view of Whitman's work continued throughout his career; in the early 1880s, the reviewer for the Detroit Post and Tribune calls Leaves "a flood of incoherent and incohesive language" in which one might find "flotsam jewels" amid "the rubbish." In a similar vein, a reviewer in the January 22, 1882 issue of the New York Times finds that "Whitman's work is like a rich garden" in which "flower and weed are . . inextricably blended."

Some reviewers emphasized how the Civil War shaped Whitman's poetic vision and work. In November of 1881, The Springfield Sunday Republican, in reviewing the most recent edition of Leaves of Grass, made an inaccurate assessment of the book's likelihood of being "prohibited" (it was found to be obscene in March of 1882 in Boston and temporarily banned from the mails) but also an intriguing observation about the way the War shaped Whitman's poetry:

[T] his book will be received, we fancy, as none of Whitman's former books have been. It will no longer be a work prohibited, but, in spite of many passages which must always keep it from a familiar place on the table, and from the perfect liberty of unformed judgments, - it will find its way into all good libraries and into many homes. For the civil war made Whitman a domestic poet, which he had hardly been before. The clear recognition and pathetic portrayal of the home affection in the Americans, not less than their patriotism and devotion to democracy, give "Drum Taps" an affectionate place in the hearts of his readers. 
These reviews, in addition to clarifying Whitman's reception in the U.S., also shed light on intriguing Anglo-American literary exchanges. Whitman was the first to provoke these exchanges with his early selfreview "A British and an American Poet," in which he aligned himself with American democracy in opposition to Tennyson, a poet who, he alleged, embodied the aristocracy of the British tradition. Whitman's self-representation as the American poet of democracy crucially informed his British reception, which, when it was favorable, often categorized Whitman's boldness and formal innovation as peculiarly American and celebrated his democratic agenda.

In the beginning, Whitman was noticed primarily in British periodicals sympathetic to democracy: the mainstream, utilitarian Westminster Review offered some extracts from the 1855 Leaves of Grass (without comment, but also without condemnation) and the radical journal The Leader ran a positive review of the same volume by George Henry Lewes, a bohemian cohabitating with the Westminster reviewer, George Eliot. In the late 1860s, Whitman's work was promoted by a number of liberal poet-critics whose own aesthetic leaned towards the countercultural: William Michael Rossetti, Robert Buchanan, and Algernon Swinburne. ${ }^{1}$ In 1868, Rossetti edited a British edition of Whitman's poems, which generated respectful and mostly positive responses from British reviewers. All this is well documented by previous reviews; what the British reviews collected here provide is a fuller account of the role of the British avant-garde in promoting Whitman's work and provoking the transatlantic conversation that helped develop his reputation.

Two reviews republished here, the notice in Dublin Review in 1874 and a hostile review by Peter Bayne a year later, document the extent to which serious consideration of Whitman's verse depended on the work of these early avant-garde critics. While in 1855 the Dublin Review had published a negative appraisal of Whitman's Leaves of Grass, by 1874 this same journal had become slightly more accepting. Despite lamenting Whitman's alienation from the Catholic Church, the reviewer recognizes "in his talents a gift of the Most High, and in his writings much that is beautiful and precious in the midst of much that is dangerous and base." Meanwhile, Peter Bayne, in the Contemporary Review, a highbrow liberal periodical, took twenty pages to excoriate his verse. Bayne writes,

If I ever saw anything in print that deserved to be characterized as atrociously bad, it is the poetry of Walt Whitman; and the three critics of repute, Dr. [Edward] Dowden, Mr. W. Rossetti, and Mr. Buchanan, who have praised his performances, appear to me to be playing off on the public a well-intentioned, probably good-humoured, but really cruel hoax. 
These "critics of repute" are mentioned on almost every other page throughout the review. It is clear that what incenses Bayne is not Whitman's poetry itself, but the seriousness with which it is treated by respectable British critics. (This may be partially an effort to hold his peers accountable for their judgments since Bayne also takes the opportunity to correct Swinburne's representation of his position on a completely separate matter.) Bayne ends his review,

As a Yankee phenomenon, to be good-humouredly laughed at, and to receive that moderate pecuniary remuneration which nature allows to vivacious quacks, he would have been in his place; but when influential critics introduce him to the English public as a great poet, the thing becomes too serious for a joke.

Bayne's review is of interest, not only because it suggests that Whitman had already gained a place on the British literary scene, but also because it is one of the few thoughtful negative reviews of the poet's work. Bayne certainly does not pull any punches, but he also judges Whitman as much by aesthetic as by moral criteria. Of course Bayne's serious treatment testifies (despite his protests) that Whitman had already arrived, a fact that the Dublin Review's more temperate response also acknowledges. In fact the New York correspondent for the London Daily Times begins his review by claiming that Whitman enjoys a reputation in England that he does not at home: "it can hardly be said that his claims to the rank of poet were seriously considered in America until they had been discussed by Mr. W. M. Rosetti [sic], Mr. Robert Buchanan, and other authorities in London." Statements like these show how much Whitman's reputation, even after the Civil War, depended on the prominence of his advocates' names.

The reviews also suggest that Whitman's reputation grew largely as a result of the mutual interest British and American critics had in each other's judgments. Not only did American periodicals frequently reprint British reviews (like the Cincinnati Daily Commercial's reprint of and addendum to a Westminster Review article), the reviewers often began by situating their opinions in relation to "transatlantic" critics. ${ }^{2}$ John Hollingshead in the Irish Literary Gazette published in February 1861 the only known review of Whitman to appear that year, and one of the earliest notices of Whitman in Ireland, attending to Whitman as Emerson's “monster" offspring. Likewise, the Sunday Times review quotes John Burroughs's biography. The Worthington Advance reviewer writes, "Whitman has steadily grown in favor in Europe and hence his own countrymen have taken him up and have gradually come to see that a great and original poet has been among them." The reviewer also tracks the intricacies of a transatlantic conversation that took place twenty years previously, when the Cincinnati Commercial reprinted and 
commented on a Westminster Review article, which The Fireside then responded to. ${ }^{3}$ These reviews give a sense of a broader conversation among the community of readers and writers.

Finally, these reviews also enrich our understanding of the British cultural scene. Whitman's poetic reception sheds light on the emergence of an avant-garde and a new divide between serious and popular poetry in Britain. Swinburne, Rossetti, and Buchanan all occasionally or regularly pushed the boundaries of socially acceptable content, and all identified with radical political agendas. As the Dublin reviewer writes,

Mr. William Michael Rossetti was principally concerned in introducing [Whitman's] works into the English market; and when it is remembered that Mr. Rossetti is the bosom friend of Swinburne, our readers will not be surprised to hear that Walt Whitman, as an author, is the embodiment of all that is most opposed to the Catholic religion.

But the Sunday Times review, which predates the important notices by Swinburne, Rossetti, and Buchanan, suggests that Whitman himself provoked a new kind of scholarly attention. Contrary to most midcentury Victorian reviews, however, while it admits that "[the volume's] contents are such as cannot possibly be admitted into family reading," it nevertheless also contends that the volume is "such as a man of culture will not care entirely to ignore." These comments suggest that the British Whitman might have gained his prestige as an avant-garde rather than as a populist poet. The divide between material appropriate for "family" reading and that which can only be consumed by an adult male audience was well established. The latter always implicitly contained the cachet of sexual knowledge, but rarely was it publicly valorized. ${ }^{4}$ Instead, most mid-century reviewers advocated popularity and widespread appeal as the true test of artistic merit. Therefore, while almost all reviews address Whitman's "indecency," favorable reviews generally respond to it by arguing that Whitman's treatment renders the indecorous content "healthy" (that which is not, after all, really indecent) or that the indecency forms only a small, regrettable part of his total oeuvre. ${ }^{5}$ The Sunday Times, in contrast, does not indicate that indecent content threatens the poetry's worth. The "man of culture" is marked as one who can consume counter-cultural artistic productions that are nevertheless high art. Add to this the alleged "scarcity" of the 1860 Leaves and its high price in the British market, and the sense of an avant-garde becomes more sharply focused. If Whitman's reputation depended partially on his introduction by "critics of repute," the Sunday Times review bolsters evidence from previous reviews about 
how these critics in turn used Whitman to help define an aesthetic built around novelty (Whitman's formal innovations) and an adult male audience that prefigured the culture of modernism.

\section{NOTES}

1 Swinburne's Poems and Ballads (1866) was almost uniformly condemned by the British press for its sexually explicit material. William Michael Rossetti was known and widely respected as a critic, but he was also associated with the Pre-Raphaelite Brotherhood, whose sensual art provoked Robert Buchanan's infamous attack in "The Fleshly School of Poetry" (1871). Buchanan himself had been criticized for drawing the subjects of his poetry from the lower class and writing about prostitutes. Although Buchanan and Swinburne were bitter enemies, they had much more than Whitman in common; they also shared an intemperate reviewing style, a commitment to democratic politics, a love of satire (including self-parody), and a tendency to write at the edge of what was socially acceptable.

2 The information we have about reprints is still incomplete, but nevertheless suggestive. The Cincinnati Daily Commercial (November 29, 1860) reprinted a Westminster Review article (January 10, 1860); the New York Saturday Press reprinted an article from the Leader (June 30, 1860); Littell's Living Age reprinted several British reviews: London Review (March 21, 1868), the Saturday Review (May 2, 1868), and Peter Bayne's Contemporary Review article (December 1875). The New York Daily Tribune (June 25, 1867) reprinted an article from the London Review (June 8, 1867).

3 As we compiled these new reviews, the number kept growing because writers so often refer to other reviews or previous articles on Whitman in their own periodicals. Newly available searchable electronic databases also helped in the discovery of materials, as did the traditional method of digging ever deeper into archives and special collections around the country as work continues on the Whitman Archive.

4 In this respect, one other comment by the Sunday Times reviewer is relevant. After listing Whitman's central ideas, the reviewer adds, "Lastly comes the notion of comradeship. This last we only partially understand, and are not in the least tempted to enter upon."

5 See, for example, the characteristic statement of the Pioneer Press: "But it must be said of [Whitman's indecency], as he says of his poems, that the words are nothing, the tendency everything. His lines are bold and startling, but you can look them through and through and find no prurient suggestiveness." 
Franklin Evans. New York Daily Tribune 23 (November 1842), 1.

\section{LEAVES OF GRASS (1855)}

"Leaves of Grass." The Merchant's Magazine and Commercial Review 34 (May 1856), 654.

There is the name neither of author nor publisher to this singular book-one of the most singular that has ever come under our notice. Appearing at the first glance to be mere unconnected common-place remarks, aphorisms, and opinions, there is yet developed, on further examination, a vast amount of undisciplined power. Many of the lines are such perfect pictures in themselves, that an artist might draw them without reference to any other material, and produce beautiful pictorial compositions. Other portions of the book are perfectly kaleidoscopic - grotesque changes rapidly succeed each other; and no one save the author himself - and he, perhaps, not an exception - can explain them. Had the elder D'Israeli met with "Leaves of Grass," he would have assuredly included it in his "Curiosities of Literature." The book is embellished with a portrait (we presume) of the author - a rather melancholy-looking gentleman, with a wide-awake hat on, and neither coat nor vest. Among the "Leaves of Grass," certainly the author himself is not the least remarkable "blade."

Other newly discovered reviews:

The New York Daily News (February 27, 1856), 1.

"Arts and Belles Letters." Westminster Review [American Edition] 42 (April 1856), 342-356. [Leaves of Grass is only discussed on pg. 356.]

"Notices of Books." Dublin Review 41 (September 1856), 267-268.

Frank Leslie's Illustrated Newspaper (December 20, 1856), 42.

LEAVES OF GRASS (1856)

Harvard Magazine 3 (January 1857), 40-41. 


\section{“A CHILD'S REMINISCENCE” (1859)}

\section{Umos?. "Walt Whitman's Yawp.” The New York Saturday Press (January $14,1860), 2$.}

The review by the Cincinnati Commercial of Walt Whitman's last yawp, ${ }^{2}$ which (the review) you were frank enough to print in your last issue, emboldens me to speak my sentiments. When I opened the PRESS containing that extraordinary concentration of words, I said to myself, here's something nice for Mrs. U. to listen to, this night, after the little U's have curled themselves up in bed. Accordingly, the desired hour having arrived, I opened the PRESS, and enquired of Mrs. U. what she knew of Walt Whitman, and I am happy to say,- - happy, after reading what the Cincinnati paper says about his "Leaves of Grass,"- that she instantly disclaimed the remotest acquaintance with any one of that name. "Then," I proceeded to remark, "he must be a poetic luminary of the first magnitude - a sort of Fresnel light — who has been, like Alexander Smith, ${ }^{3}$ hiding his brilliancy under dry goods boxes or flour-barrels, and now blazes forth to amaze the readers of the SATURDAY PRESS, and the rest of mankind. Listen; it's good, or it wouldn't be here."

I began. ... .

Last Winter I got on skates, by first appearance before an icy audience for fifteen years.

Happily for me, I selected the night and a retired spot. Unhappily, that the-infernal, I was going to say, hyperborean is better-hyperborean idea ever entered my wretched head; and for its weakness that head paid a fearful penalty.

I cherish a vivid remembrance, that on that fearful night there was an irrepressible conflict between my several members. No two of them would go the same way, and when they did, it was not the way I wanted them to go. The only consentaneous movement which they seemed at all disposed to execute, was a spasmodic, unsolicited, and uncontrollable flight ad astra, in which my head foolishly refused to participate, and for its contumacy was left behind, the stars being so obliging as to come down in dazzling throngs to gaze upon my helplessness. I remembered the story of Miller at Lundy's Lane, of Bruce (was it?) and the historical Spider, who tried twenty times before he hauled himself up, and I didn't give it up so, O Editor! but "tried, tried again," until I believe the closed-up sutures in my cranium were opened as widely as if the brains were out, and a pint of white beans were in with the whole caput-al arrangement-soaking in the Anatomist's basin. Such a wild, heterogeneous insane Saint Vitus-like, poly-maniacal orgie, as my shapely and generally well-behaved branches went into that night, will never be forgotten. ${ }^{4}$

I said I began to read Walt Whitman's Yawp.

Pardon my digression-I have been trying to say that I felt as I was reading, that Walt - whatever that stands for-was on his musical skates for the first time. ${ }^{5}$

O Shakespeare, O Milton, O Longfellow, O Henry Clapp junior, Editor of the nicest paper in the country-I couldn't see it!

I told Mrs. U. so-I asked her what you, O Editor meant by publishing such wretched trumpery? She had not been favored with your confidence, and said she didn't know. But she didn't think it trumpery-she thought there was something in it.

As Mrs. U. is the poet of my concern, her suggestion to that effect was a strong point in favor of Mr. Whitman's barbaric Yawp.

Furthermore, as Mrs. U.'s fondness for poetry doesn't at all interfere with the clearness of my café noir, the lightness of my muffins, or the integrity of my shirt-buttons, I respect her poetical opinions to every extent consistent with my lordly prerogative. 
So I attempted the Yawp again.

Like as Mr. Webster said to the dandy who asked him if he never danced, "I never had intellect enough to learn," so I say — and I say it with grateful humility - "I haven't poetry enough to understand Walt's Yawp." More than that, I don't want to.

My private opinion expressed to you confidentially is, that Whitman found a lot of dictionary-pi going off at auction, bought it for a song, employed a Chinese type-setter from the Bible House to set it up in lines of unequal length, and then sold it to you as an original Poem.

\section{LEAVES OF GRASS (1860-1861)}

\section{The New York Saturday Press (June 2, 1860), 4. [Reprinted from the Albion (May 26, 1860).]}

Messrs. Thayer \& Eldridge have published a third edition of Leaves of Grass, in which we recommend our reader endeavor to find the following passages:

1. I happify myself.

I am considerable of a man. I am some. You also are some. We all are considerable, all are some.

Put all of you and all of me together, and agitate our particles by rubbing us all up into eternal smash, and we should still be some.

No more than some, but no less.

Particularly some, some particularly, some in general, generally some, but always some without mitigation. Distinctly, some.

$\mathrm{O}$ ensemble! $\mathrm{O}$ quelque-chose!

2. Some punkins, perhaps.

But perhaps squash, long-necked squash, crooked-necked squash, cowcumber, beets, parsnip, carrot, turnip, white turnip, yellow turnip, or any sort of sass, long sass, or short sass.

Or potatoes. Men, Irish potatoes; women, sweet potatoes.

[Parody continues for another fifty-three lines.]

The above was written, and almost all in type, before we were aware that any similar notice had been taken of the book to which it refers; for until within a day or two, our knowledge of Walt Whitman was limited to what we had heard in casual conversation. But our attention is just now called to a little pamphlet-collection of notices of the previous editions of 'Leaves of Grass,' and by that we find that we have been forestalled in two instances. Had we known this we should have written otherwise; but as it is, we let our squib go. We admit that although there is no verse in Mr. Whitman's book, there is 
some poetry - a little — of an exquisite and peculiar cast, which flecks the surface of a very copious and strong expression of sympathy with and close observation of external nature. But the latter is not necessarily poetry, even when written by a poet of transcendant powers. Witness the description of the horse in Shakspeare's 'Venus and Adonis,' which is an enumeration of points better suited to Tattersall's books than to a work of fancy and imagination. ${ }^{6}$ As to these 'Leaves of Grass,' nine-tenths of them are covered with words that have no more meaning, coherency, or perceptible purpose than the columns in a spellingbook; while the indecency - an indecency not born of prurience, but of the absolute refusal to recognize such a distinction as decent and indecent - is monstrous beyond precedent, and were it not before our eyes, beyond belief. Yet for the one-tenth that we have excepted we shall keep the book, and read it, not without a strange interest in the man who could draw such a slender thread of truth and purity through such a confused mass of folly, feculence, and falsehood.

Messrs. Thayer \& Eldridge have printed the book in very handsome style.

\section{"A New American Poem." Southern Field and Fireside (June 9, 1860), 20 .}

It has been a favorite subject of complaint with English critics and reviewers, in treating of American Civilization, that in this country we have produced as yet no peculiar, distinctive literature of our own, and that all our efforts in polite letters have been but feeble imitations of English originals, lunar reflections, as it were, of that intellectual sun which, we are told, still rises for us over the Atlantic. Thus, they allege, we refer to Cooper as "The American Scott," Emerson is Carlyle and water (and very muddy water, in the present writer's humble judgment), the North American Review is a poor copy of the Edinburgh, and so forth. But especially do they reproach us with a lack of originality in the poetical form of composition. There is fancy and sweetness and music, they admit, in our poets, but we can point to no one great poem on which is stamped the impression of a new and mighty continent, which is fragrant with the fresh odours of the unpruned-forest, whose rhythm, mighty in its movement as the wind rushing over the limitless prairie, bears the reader along unresistingly - a poem, in short, full of the energy, the passion, the vim of large-veined, stout-breasted, hopeful, wide-awake, goahead Young America. But the reproach can be made no longer. We have an American poem. Several of them. Yes, sir. Also a great original representative mind. 'The hour and the man' have arrived, the man who knows what's o'clock and always comes up to time. The name of this wonderful poet is Walt Whitman, and his verdant volume of verse is called "Leaves of Grass."

Perhaps we are wrong in referring to these "leaves" as verse. We used that term for want of a better one, and having in mind the definition of the master in the Bourgeois Gentilhomme-Tout-ce qui n'est point prose est vers, et tout-ce qui n'est point vers est prose. ${ }^{7}$ Worthy Monsieur Jourdain was astonished, as Moliére makes him confess, to discover that he had been speaking prose all his life without knowing it, but the master would have experienced a much greater degree of amazement, could he have seen his theory demolished by a poem like any one of these by Walt Whitman. Here is something which is neither prose nor verse, which writes itself out in long or short sentences, as the case may be, disdaining the shackles of rhyme or measure, and sounding to the ear alternately like the click of the instrument in the Telegraph office, the roar of Buttermilk Falls, ${ }^{8}$ the eloquence of the Razor-Strop man, the buzz of a wheat-machine, the braying of an ass, the cries of 'the boys' running to a big fire with No 40, the animated evening conversation in a Lager Bier Saloon, and a campaign speech in the House of Representatives. 
Mr. Walt Whitman is to us, however, no "new Nebuchadnezzar,"nor has the "Leaves of Grass" been brought to our notice now for the first time. ${ }^{9}$ Five years ago we recollect to have seen the first edition of it, and to have made up our mind that if it did not proceed from a lunatic, it was designed as a solemn hoax upon the public. The extravagance of the style, the beastliness of the sentiments, the blatant blasphemy of the whole performance, its profanation of every tender and holy impulse, its frequent indecency of language, all suggested Bedlam. The bizarre appearance of the book also indicated a crazy origin. The page, about half the size of our own, was printed in type as large as that of a playbill, the presswork seemed to have been done with a sledgehammer, and the frontispiece was adorned with a full length portrait, in the finest steel engraving, of Walt Whitman, in which, without other garment than shirt and pantaloons, his sleeves rolled up and arms akimbo, he appeared to be doing his best to look like a rowdy and a vagabond, and with greater success, it must be admitted, than ordinarily falls to poor human endeavor.

After the lapse of a lustrum, not so long a time as was recommended by the Latin critic for keeping a poem before publication, the profane bestial rigmarole is again brought before the public, enlarged, altered and rendered, if possible, more disgusting and abominable than in its pristine shape. If the present edition had excited no more comment than the first, we should not have taken the trouble to refer to it. But it has been widely noticed and even applauded, an immense amount of advertising has been expended upon it by the publishers, and there is danger that it may find its way into respectable bookstores and even pure households, by reason of the attention it has received. To save the latter from moral contamination and the necessity of using disinfectants, we feel bound to say so much by way of caution as will enable them to learn the true character of the volume. Not that we would pollute our columns with quoting any of its vilest passages. It will suffice, we hope, to say that Walt Whitman glories in materialism of the most degraded kind, that the animal passions call forth his loftiest admiration, and that man as a brute, in his earthly relation to the beasts that perish, not in his kinship to immortal beings, is the object of that faculty which in the Walt Whitman organization takes the place of reverence. Not only is he without the means of discriminating between the pure and the impure, but the Chevalier Bayard ${ }^{10}$ is no more to him than a chicken cock, Tennyson is no higher in the scale of created things than a tadpole, and he can perceive no difference between Bacon and a Berkshire pig.

And yet all this is mixed up with constant references to the soul, of which he assumes to be an interpreter. Hear what he says of himself-

[Two lines from "Proto-Leaf" and ten scattered lines from "Song of Myself," $L G$ (1860), 20, 30, 49, 89, 93]

A clever parodist, in the New York Albion, thus imitates Walt Whitman in lines which he will find it difficult to tell from his own.

I tell you the truth. Salut!

I am not to be bluff'd off. No, Sir.

I am large, hairy, sprawling, big in the shoulders, narrow in the flank, strong in the knees, and of an inquiring and communicative disposition.

Also instructive in my propensities, given to contemplation and able to lift anything that is not too heavy.

Listen to me, and I will do you good,

Loafe with me, and I will do you better.

And if any man dares to make fun of me, I shall be after him with a particularly sharp stick.

Vale!

The following from "Leaves of Grass" has been cited by a very competent critic as a fine specimen of "power, pathos and music." It is a funeral piece- 
[Eight lines from "Burial," LG (1860), 442]

We very frankly confess ourselves unable to recognize the force, the feeling, or the melody of the passage. The last line or strophe or stanza, or whatever it may be, is a good portraiture, but we like this from the Albion much better-

Once I knew a man.

Not that man.

But another man.

A man I once knew. He was great, 'was glorious, nev'r washed his hair, n'r combed his face,- - 'mean combed face n'r washed hair; had big han's - dirty'n big feet-dirty, - red 'n freckled, 'cause did n't wear hat, n'r coat, n'r shoes, but went bare headed ' $n$ bare footed, ' $n$ shirt ' $n$ pants like free ' $n$ in-in-in'pen't citiz'n these 'nited States.

'Swear he was glorious.

This is no bad picture in words of the steel engraving of Walt Whitman himself, in the first edition of "Leaves of Grass."

In dismissing the consideration of this new American poem, let us say that we think we can discern the reason why it has been raked up from its long sleep among the buried corruptions of the past. Walt Whitman is the poet of prizefighters, the minstrel of muscle; his is the song of sinews, the burthen of brawn, and he thinks naturally enough that the age and generation which could delight in the Mill of the Champions, ${ }^{11}$ must applaud the apotheosis of brute strength. Among the Heenan-ities of the day, ${ }^{12}$ his verse may find admirers, but with all the votaries of a pure literature, he must be greeted with a "Procul, procul este profani!"'13

\section{Henry P. Leland. "Walt Whitman." The New-York Saturday Press (June 16, 1860), 1. [Reprinted from the Philadelphia City Item, not located and perhaps no longer extant.]}

If ever there was a period when poetry needed a Luther now is the time. The vine long unpruned has run itself to waste; graceful lines, spiral tendrils, flaunting leaves, but very little fruit. The reformer and the vine-dresser are at hand-do you think we will let him go on unmolested? Never; there will be a hard fight. We are attached to old abuses, we love the shadow of the vine, and smoke the pipe of peace under it, watching those exquisite twistings and turnings of branch and tendril. The fevered lips of the poor are parched-there are no grapes to cool their system. Ma foi, why don't they send to Malaga? ${ }^{14}$ We gain our living pointing out to each other the exquisite ground-and-lofty tumblings of agile creepers, running here, there, everywhere. Hang your grapes!

Hang your reformers! They have sent the exquisite refinement and easy-flowing lines of the renaissance-period flying, they would revive a task for Nature; - teach us to walk instead of dancing the pas rococo of blessed Louis Quatorze; -revere and respect cocked-hats and small clothes of the Revolution, and neglect the tunic and toga. They would have us quit bragging about the exquisite beauty of Homer as we read it in the vernacular and woundily vowing how impossible it is to read Quevredo, ${ }^{15}$ or Dante, Racine, or Goethe in a translation; they would have us believe that their marrow has been long since collected and digested by those ignorant of everything save English, and that we are now crowing over a bag of bones! This is woful!

Here is a man-Walt Whitman-coming smack at our aesthetical vine with a large knife-a bowie-knife. What is it best to do? Those old-world conquerors, the Romans, carried just such tools, and Americans of all nations now extant, are the only ones daring to wield such close-quarter reasons. Suppose we out rapiers, on guard, carte and tierce-now for the salute: by way of compliment let us ask him to thrust first at us; we 
drop our point by reversing the nails downward - with a circular motion; draw our right foot close by our left, stretch both hands; raise our right arm, and with our left-hand take off our hat gracefully. The devil! The man has rushed by us - made one drop-and the vine is good for nothing-but grapes!

He has placed before us his poems. And what collective name has he given them? Something sounding - something like 'Songs of the Faineant,' 'Lays of other Lands,' 'Seaside Dreams,' or the 'Muse's Meanderings!' Not a bit of it; but plain 'Leaves of Grass'-something cows eat and milkmaids wipe their shoes on. Then he has entitled his poems 'Proto-Leaf,' 'Chants Democratic,' 'Enfans D'Adam,' 'Poem of Joys,' 'Messenger Leaves,' 'Calamus,' 'So Long,' etc., etc. And here we have his portrait-a head of Homer painted by Hans Hemling ${ }^{16}$ - a good deal of primitive grit toned down by Flemish caution. A face for open air and the woods and psalms of muscle.

He sings very little for the opera, but for oyster-men and clam-diggers, and Western hunters and raftsmen, and farmers and red-cheeked matrons, and omnibus-drivers and mechanics; and for all true Americans, he whistles like an oriole of a warm May morning. He sits down by you familiarly, but not 'famillioniarely,' and tells you of Rocky Mountains, primeval forests, Southern bayoux, Northern lakes, Western prairies, Eastern rock-bound sea-shores, far-stretching prairies, scenes of sunlight, and fresh blowing air. He is great on politics, and the duties we owe our country. He advocates cleanliness, fresh air and exercise; he proves that because a man may be thrashed in a fight it is no reason that he was in the wrong. He is Consuelo for the poor man, ${ }^{17}$ the friendless, the outcast - he picks them up from the gutter and sets them up straight. If he has a dime in his pocket he evidently gives the poor devil ten cents of it. Certainly he is lacking in one of the chiefest of our attributes - making money. He tells you he is as good as you are, and that you are as good as he is - and evidently does not worry his great soul about trifles.

If you intend to sail in the same fleet with his clipper, you must first be careened over and scrape off the barnacles of old books, before you up sail for blue water.

$\mathrm{He}$ is the people's Poet, and spite of a belief that poetry only can be appreciated by the few, he goes in for giving it to the [h] oi polloi. It's a fact that-

'When coarser souls are wrapped in sleep'-18

we may out with a mandolin and sing to Leonores and Josephines-but we have to make it up next morning and we do sleep sometimes; so the poetic element in uneducated people as in the educated, sometimes and somewheres exist. Not a fierce revolution in this world's history but may be regarded as a grand psalm in the Book of Time, sung by the poets of deeds - the people.

This poet has a peculiarity. He calls a tom-cat a tom-cat; therein we differ from him. It is a well received truth that in our day it is politic to look at a great many things as they are not. We crowd to see La Dame aux Camelias, to hear the Traviata, but we do not call the French girl, or her Francesca Italianizata sister, by their old Anglo-Saxon name. ${ }^{19}$ The farthingale and silkworm cover a multitude of sins, and elegant language many a vile, voluptuous thought. We may not be Spartans; -it seems the prayer of Whitman that we may not degenerate into Sybarites, and to prevent this he uses the crash-towel of bold words. ${ }^{20}$

America must make her distinctive mark. Already over our Past falls the bridal-veil of Romance, wedding it to the Future, though its thin cloud, its exquisite beauty and loveliness seem more bewitching than when it was our Present. In the Revolution of 1776 lie undelivered the subjects for a thousand poems to which the Iliad of Homer will be but as a rushlight to a conflagration. To the glories of our Past and the beauty of our Present, Walt Whitman awakes us; rough, bold, and free, he bursts out in the roaring old song that might have cheered the Old Continentals bivouacked for battle. And the words will thrill many a heart even in our day, clad though the body may be in homespun in far Western homes; grimmed [sic] though it may be by coal-dust and machinery, or wearing out life 
toiling away where brown earth, blue skies, pure air, green fields, and all God's gifts to man are driven ruthlessly aside that we may give more room for Mammon.

Before we condemn the book, let us read it. Before we cry out 'Eccentricity!' let us investigate our own centre, and the teapot we are making such a tempest in. There are two thousand roses to a drachm of the otto, there are untold thousands of poems in this duodecimo; ${ }^{21}$ you are given ideas! Now attention! present arms! Fire Words!!

\section{“'Leaves of Grass'-Smut in Them." The Springfield Daily Republican (June 16, 1860), 4.}

Some weeks or months ago, we remarked upon a poem published in the Atlantic Monthly, from the pen of Walt Whitman-a nonsensical, whimsical scraggy performance, about as much like poetry as tearing off a rag, or paring one's corns. Recently the writer has appeared in a large volume, (published in the puritanical and transcendental city of Boston, by Thayer \& Eldridge, who we hope are willing to stand the notoriety of it,) and a more scandalous volume we never saw. We had not intended to notice it, but certain of the soft heads, on the shoulders of men and women indiscriminately, have conceived that it is a pure book. In the last number of the New York Saturday Press, Mary A. Chilton gives her ideas of Walt Whitman's poetry generally, and especially of his smut; and to show the public how far into degradation certain new lights are ready to be led, we quote a portion of her letter, simply italising such sentences as we wish to call special attention to:-

"In childhood there is no blush of shame at sight of a nude form, and the serene wisdom of maturity covers this innocence with a halo of glory, by recognizing the divinity of humanity, and perceiving the unity of all the functions of the human body, and the inevitable tendency to harmonic adjustment and adaptation. As all of nature's forms are evolved from the same God-origin or substance, though there may be difference of rank, there can be no difference in essence; and those functions which have been deemed the most brutal and degrading will be found the first in rank when nature's hierarchy shall be established and observed. A true delicacy will neither emblazon the individual act of communion abroad (as, sanctioned by custom, those who lay claim to the highest refinement do daily,) nor blush to a crimson when the poet of sexual purity vindicates manhood and womanhood from the charge of infamy, degradation, and vice, on account of growth and development after the order of nature. Of course those who assert the doctrine of total depravity must find some part of the person too vile to think of, and will be shocked to hear another express unqualified admiration for the human body and the human soul."

A professedly obscene book carries with it its own condemnation among decent people, and finds its own market among the vicious and unclean. Besides, there are laws against its promulgation; and appeal can be made to them if it is openly exposed for sale, or advertised, or sold more secretly. This literature is not unfrequently stuck in one's face at steamboat landings by lousy scoundrels who peddle filth for a living, but one can always cry "police" if he will, and stop it. Here, however, is a book with many respectable associations - respectable publishers - the author a writer for the Atlantic Monthly - "for sale everywhere" on respectable bookshelves - in very respectable type and binding - advertised in respectable papers - and yet it has page after page that no man could read aloud to a decent assembly without being hooted out of it, and that could not be published in the columns of a daily newspaper without disgusting and outraging 
a virtuous community. The dangers of the book lie in its claiming to be a respectable book-in its claiming to be a pure book, and in the fact that there are lecherous fools enough in the world to allow this claim, if not to maintain it. We are inclined to think that the author considers the book a pure one. It costs some charity to admit this, and a large allowance for eccentricity of mind and temperament; but, making the admission, we are at liberty to comment on that phase of infidelity of which it is the outgrowth.

Nothing is more notorious than the fact that when any individual claims to have some light superior to that revealed in the Bible, whether that light be the "light of nature," simply, or the light of new and direct revelation or inspiration, then that individual almost invariably develops himself towards libertinism. Perhaps this fact is more notorious when we find men in masses, as in the various sects that spring up from time to time. William Dorrel who, seventy-five years ago, proclaimed himself the Messiah up in Franklin county, counseled promiscuous intercourse of the sexes and taught as vile stuff as our very natural poet Walt Whitman does now. ${ }^{22}$ The Mormons, with their new Bible, ran straight into the most disgusting polygamy; and Heber Kimball talks in the most promiscuous congregation of the saints as easily and freely of his "cows," as our "poet of sexual purity" does of women. ${ }^{23}$ Spiritualism, whenever it has cut loose from the Bible as the only authoritative revelation from heaven, has gone just as naturally into free-love as water runs down hill. The very first social institution that falls into contempt after Christianity as a revelation is discarded, is Christian marriage, and of all the 'teachings' in the world, we know of none that so inevitably lead to impurity as those attributed to "Nature."

Now Walt Whitman is par excellence the "poet of nature." In his pure taste there is nothing unclean, because nothing seems unclean. Nature has free course in him, and runs and is glorified in all its issues. Those passions which degrade men and lead to nine-tenths of the crime of the world, he exalts. Those appetites which only a pure, true and life-long love can hallow, are with him appetites to be cherished and fed-no matter about the love. It ought to be enough for Walt Whitman, if he honestly thinks his book a pure one, to know that the pure in society will shun it, and that it will be sought out and laughed over by lewd women and prurient boys and hoary-headed old lechers, - to know that this notice of his volume will stir to read it only the dregs of the social and moral world into which it goes. That settles the question. When men and women are led by their higher affinities, they will be led straight away from Walt Whitman's "Leaves of Grass." Otherwise, otherwise.

\section{"Leaves of Grass.” National Quarterly Review [New York] 2 (September 1860), 515-517.}

If it be an essential attribute of poetry to afford pleasure and delight to the mind, in proportion as the latter is refined by culture, the performances, entitled "Leaves of Grass," have little claim, considered as a poem, to that title; for in no work of the same size have we ever read so much that is disgusting and repulsive. The author seems to exult in being as indecent, obscene, and profane as possible. This is the more to be regretted, because, in the midst of a great deal of the silliest twaddle, and the most unmeaning bombast, we find thoughts of rare beauty and striking force, wonderful felicity of expression, and imagery at once the boldest and most pleasing. Nor are the passages of the latter kind by any means few; although, undoubtedly, the predominating qualities throughout the book are coarseness and vulgarity; so that we often meet with whole stanzas which are too filthy to be quoted. There is a modesty in nature herself, which those who understand her will not overstep; but Walt Whitman (for this we understand 
is the name of the would-be Homer) goes beyond nature, or rather, in most cases he fails to reach her. Decency requires that we sometimes draw a veil over what is natural; but though such is hidden by common consent, it is not absurd or revolting like many of the images and precepts of Mr. Walt Whitman. We have, now, neither time nor space to illustrate our remarks by suitable extracts. We will, however, give two or three, which we think will sufficiently justify our views, if they do not give a correct idea of the true character of "Leaves of Grass." Such egotism and bravado as the following, are to be found at almost every page:

[Six lines from "Walt Whitman," $L G(1860), 55$.

Be it observed, that this is chaste and decent compared to what follows, but which we take care to omit. Nor is he, generally, much more pleasing or poetical in his scenic descriptions. Thus in describing a sea-fight, he sings (?):

[Two lines from "Walt Whitman," LG (1860), 78.]

As a specimen of his patriotism, we give one stanza:

[Six lines from "Calamus-35," LG (1860), 374.]

Leaving poetry out of the question, it would be difficult to find duller prose than this. Yet, as we have said, Walt Whitman can be occasionally musical, tender, and pathetic. As an instance, we quote a part of a death-bed scene, which is as beautifully drawn as it is truthful and touching:

[Twelve lines from "Burial," LG (1860), 440-441.]

Nor is this, by any means, the best we could cull from the pages of "Leaves of Grass." We have read and reread in it many passages much more exquisite; but nevertheless, we cannot regard Walt Whitman as a true poet. That he has genius there can be no doubt, though it is certainly not of a high order. In wading through his uncouth rhapsodies, we are reminded of the pompous, but generally empty speeches which Homer puts into the mouth of Paris, especially of that line in which he makes Helen inform us that the braggart libertine was but ill supplied with sense-

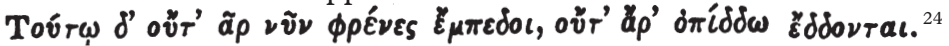

The publishers have done their part well. A better printed book, coming even from Boston, we have not seen in a good while. We have never seen Walt Whitman to our knowledge; nor do we know anything of him further than we learn from his book, but we think there is reason to fear that he will be too much read by a class of persons not capable of picking the diamonds out of the putrescent filth in which they are imbedded.

\section{John Hollingshead. "A Wild Poet of the Woods.” Irish Literary Gazette and Register of Facts and Occurrences Relating to Literature, the Sciences, and the Arts 4 (February 1861), $126 .{ }^{25}$}

Each literary man of any distinguished mark or position has raised at least one monster, who seizes his style, his principles, his peculiar modes of thought, and carries them headlong downwards into the great gulf of absurdity. This Frankenstein, - this attendant spirit,- is faithful, but unruly. It multiplies every action, whim, or fancy that it copies by three or four; it leaps higher, dives lower, speaks louder, and goes farther than its master; and often succeeds in so far dazzling a certain circle of admirers that they prefer the coarse copy to the pure original. [...]

Walt Whitman, or, as we should prefer to call him, Emerson's monster, or wild poet of the woods, is a thoroughly untamed, muscular, unconventional writer. What Emerson talks about doing, or seems to wish to do, Walt Whitman to all appearance does. Emerson only asks for health and a day to make the pomp of emperors ridiculous; Walt Whitman has got health of the rudest kind, with many days, and he glorifies the whole weighable, pinchable, material universe. No form or manifestation of matter is mean or 
contemptible to him. Like the great practical poet, alluded to in our last number, ${ }^{26}$ he would chant a great guano lyric, ${ }^{27}$ though with a far louder voice, and in a very different tune. If he fell in a gutter, he would rise up shaking his muddy locks, and dash onwards like the "strong-breasted bull" which meets with his admiration. He describes himself in a coarse, sing-song, rugged stanza as, -

[Four lines from "Proto-Leaf," $L G(1860), 5$.

He might have added in plain prose, and no one would have discovered the difference,"fond of rump steaks and oyster sauce, legs of mutton, pots of beer, cart-horses, wrestling, and lifting weights." He chants in this strain page after page:-

[Three lines from "Proto-Leaf," $L G$ (1860), 20.]

The dustman, the "navvy," the slaughterer of oxen, have at length found their poet. He sings the song of all creation. His invitations have no limit:-

[Six lines from "Walt Whitman," LG (1860), 46-47.]

The entertainment is the same, whether for man or for beast. If anything, perhaps, Walt Whitman has a partiality for the beast:-

[Three lines from "Walt Whitman," LG (1860), 37-38.]

Every word of this might have been written by Emerson muscularized;-by Emerson at the age of thirty-two, trained by a New York "rowdy" into a state of firm, animal, pugilistic vigour. To come a little nearer home, every line might have been written by one of Barclay and Perkins's draymen, by a Rotherhithe coal-whipper, ${ }^{28}$ by a Billingsgate fish-hauler, a canal bargeman, a sewer-cleanser, a meat-porter at Newgate market, or an average pot-boy who had learned to read and spell. What Dr. Johnson said of the famous Percy ballads, ${ }^{29}$ may be said of poems like these "leaves of grass;"- they can be spun by one at the rate of six yards an hour. This is a chant of the lands:-

[Seven lines from "Proto-Leaf," $L G$ (1860), 17.]

This goes on for many pages more, and there is really no reason why it should ever stop at all. Cyclopædias, commercial dictionaries, directories, and such books are plentiful enough, and in the slang of our wild poet of the woods they contain thousands, millions of such poems. Everything is a poem in the Walt Whitman sense, as everything, by a similar wrenching of language, might have been called a fish-kettle, a pitchfork, or a blacking-bottle. There used to be a favourite class of comic songs which proved all men to be gardeners, scrubbing-brushes, or lucifer-matches, according as the whim started. These dreary pieces of laboured humour are not as popular now as they were twenty years ago, but Walt Whitman, if he gains such a hearing here as he has in America, ought certainly to bring them once more into fashion.

There is a certain philosophy in all this muscular poetry,- - the philosophy of making money by creating a sensation. The world is always on the look out for anything wild, strange, and eccentric. If Walt Whitman had had the power or the inclination to put his common-places into intelligible forms and language, the "leaves of grass" would never have made hay while the sun shone. The tricks of authorship are not yet half catalogued, or half exhausted. We must have treatises upon logic written by street tumblers, or rather we must have authors of such works keen enough to take to street tumbling to stimulate the sale of their books. We must have an epic poem written by the keeper of a Shoreditch baked-potato-can, or rather we must have the writer of an epic poem go out with a potato-can to make his poetry popular. The science of advertising is in its infancy, and America, so it seems, can give the mother country a "few wrinkles" on this subject. When Walt Whitman, as the story goes, drove an omnibus along Broadway to oblige the regular driver, who was laid up with a fever, we have no doubt that his charity proved a remarkably good investment. We have no means of overhauling his publishing accounts, to see what effect the public excitement had upon his "editions," but we have no doubt that many people never bought his book until after they found him driving an omnibus. 
As it is not fair to blame the son alone while the father is living, we should like to have Mr. Emerson's calm opinion of his literary offspring. The rumour runs that the philosopher is rather proud of his wild poet of the woods, and reads the "leaves of grass" with infinite pleasure. If this is so, he must be deceived by the poet's "yearnings after the infinite," which are about as intelligible as a dog's baying at the moon. The inventory of nature is the only thing solid in a book, one-half of which is quite as coarse as Rabelais, and just as obscure. The passages that look profound are not worthy of sustained thought and investigation, because they are deliberately made nonsense-riddles that never had an "answer."

\section{"Walt Whitman's Works."* [London] Sunday Times (March 3, 1867), 7.}

To ninety-nine out of every hundred educated English readers, if not, indeed, to a larger proportion, the name Walt Whitman conveys no meaning or associations whatever. Of the few, moreover, who have previously heard the name still fewer have had the opportunity of seeing the work to which it owes whatever celebrity it may have attained. Yet its bearer is a man of some mark in America, and his work has not only startled the few educated Englishmen who have seen it, but is undoubtedly destined to hold a prominent position in American literature. Many causes contribute to render Leaves of Grass, as Walt Whitman's principal work is called, a sealed book to English readers. The first reason is its costliness. A dozen copies would scarcely, we should suppose, reward the most diligent search that could be instituted through England, and, probably, not a quarter of that number is on sale. When met with at the establishments of the principal American bookselling agents, the price of the volume is as much as is asked for the complete works of Tennyson or Swinburne. A second reason for the scarcity of the book is that the form of its composition is not at first glance attractive, and that its contents are such as cannot possibly be admitted into family reading. Leaves of Grass, is, however, the most thoroughly national and characteristic American poem that has yet seen the light, and is a work the influence of which will yet be felt. It is a book concerning which Englishmen ought to know at least a little. For various reasons, then, among which figures prominently the difficulty in obtaining the volume, we hold we are rendering a real service to our readers in bringing under their observation a few striking features in this remarkable and most suggestive work.

We have spoken of it as national and characteristic in the fullest sense, and so it is. An Englishman might have written ninety-nine hundredths of American poetry. Scarcely a line or stanza in Longfellow, Holmes, Bryant, Whittier, that is in the fullest sense American. The philosophical poems of Emerson have a flavour of nationality, and a very strong taste thereof pervades such comic works as the Big[e]low papers, and other similar productions. But those comic works which aim at satirising the manners and customs of every-day life are necessarily the first parts of a young nation's literature, in which local colour is observable. Before the appearance of Leaves of Grass, no serious American work was wholly or in any wide sense national. The spirit that pervades Leaves of Grass is essentially American. It is more. To use a word the author is fond of, it is Manhattanese. A resident in the capital of the Empire State alone could have produced it. The rowdyism and greed of New York life, as well as its higher qualities, pervade it. Walt Whitman is as completely a NewYorkist as Charles Lamb was a Londoner or Christopher

*Leaves of Grass. Boston: Thayer and Eldridge. London: Trübner and Co. 
North a Scot. Not that he is uninfluenced by preceding writers of other countries. On the contrary, his work is, to some extent, an olla podrida of other people's thoughts, ${ }^{30}$ manners, and forms, but the main current belongs to New York. The philosophy and theology are decidedly American, the ethics are altogether of NewYork. We seem to trace half-a-dozen authors in Walt Whitman. The freedom and coarseness of his phraseology recal[1] Rabelais. In his most poetical passages he reminds us of Ossian. His philosophy has a flavour of Emerson; his constant display of independence and his peculiar habit of self-assertion, find no parallel save in George Wither; and his didactic breathings are in form, if in nothing else, at times suggestive of Tupper. ${ }^{31}$

Leaves of Grass is a volume of nearly five hundred pages, of what the author considers and calls poetry. It is divided under several heads, the most important of which are "Walt Whitman," "Chants Democratic," "Leaves of Grass" (which gives its title to the whole), "Enfans d'Adam," "Calamus," and "Messenger Leaves." All are alike in shape. Though called poems, the contents of the entire volume, one short passage in which the rhyme may be the result of accident excepted, have neither rhyme nor metre. The poems have a long rhythmic flow, which bears about the same relation to ordinary poetry that the military or mournful music of a savage tribe does to music as understood in Western Europe. The verses are of unequal length, ordinarily possessing a caesura and a strongly-marked accent on the penultimate syllable. This last quality is, however, not always observable. To quit form, however, and come to what is more important, matter, there are three pervading ideas in the volume, which may be described as the apotheosis of the flesh, the exaltation of states life, and the promotion of comradeship. To deal with these seriatim, in the first Whitman takes part in a natural and easily comprehensible reaction, signs of which have of late manifested themselves, against the extreme glorification of the soul at the expense of the body, which has been one of the results of Christianity. ${ }^{32}$ Heathen teaching held soul and body of equal account, and the Greek regarding each with equal reverence, was at as much pains to cultivate the powers of the one as is the other. The belief in the equality of the body with the soul largely pervades the writings of Whitman. Next to this comes his exaltation of democracy in general, and of American democracy in particular. Lastly comes the notion of comradeship. This last we only partially understand, and are not in the least tempted to enter upon. These are the views which first recal[1] themselves upon rising from the accomplished perusal of Leaves of Grass. A hundred other points, however, require mentioning ere we can profess to bring before the reader Walt Whitman as he really is. It is time, however, to give the reader a few quotations illustrative of the author's modes of thought. Fortunately, in so doing we give an insight into the nature of his verse also. We are obliged to be guarded in our selections. It is not possible to quote the passages which are in the fullest sense characteristic. Neither is it possible in the space we have allotted ourselves to give more than the feeblest conceivable idea of the nature of the contents of the remarkable book before us. [...]

But we can extract no more. Our space forbids, and, inadequately as our task is accomplished, we must retire from it. Our readers have seen enough of the book to have an idea of it and the author. To know all his talent and eccentricity is impossible till the book itself has been perused. The contents of the volume can by a stretch only be called poetry. They lack its first and most indispensable element, beauty. They are, however, strange and most suggestive reading, and such as a man of culture will not care entirely to ignore. Spite of barbarous expressions, vile Americanisms, and all faults of thought and expression, the writings of Walt Whitman are full of character, and well worthy of contemplation. They will in time attain a certain measure of celebrity even, and their author is surely entitled to a distinct niche in American literature. With this short notice we dismiss him as he dismisses himself- 
"I bequeath myself to the dirt, to grow from the grass I love,

If you want me again look for me under your boot soles."

Meantime, we hope, we have brought him before the reader as he stands-

"Sounding his barbaric yawp over the roofs of the world."

\section{Other newly discovered reviews:}

Juliette H. Beach [Calvin Beach]. "Leaves of Grass.” New York Saturday Press (June 2, 1860), 2.

"Short Notes on New Books."Washington Daily National Intelligencer (July 14, 1860), 2.

[William Dean Howells]. “A Hoosier's Opinion of Walt Whitman.” New York Saturday Press (August 11, 1860), 2. [Reprinted from the Ashtabula (Ohio) Sentinel (July 18, 1860), 4].

T. V. "Walt Whitman," Liberator 30, no. 36 (September 7, 1860), 143.

"Walt Whitman's Dirty Book." Cincinnati Daily Commercial (November 29, 1860), 3.

\section{LEAVES OF GRASS IMPRINTS (1860-1861)}

\section{[Walt Whitman]. "Leaves of Grass Imprints.” Brooklyn City Nerws (October $10,1860)$, page number unknown.}

In this little supplement, (a sort of wake after the ship,) appear to be gathered a portion of those notices, reviews, \&c., (especially the condemnatory ones,) that have followed the successive issues of Walt Whitman's Leaves of Grass. The history of that composition, so far, is curious. It has already had three births, or successive issues.

The first issue of the poems consisted of a thin quarto volume of 96 pages, in Brooklyn, in 1855. It comprised eleven pieces, and was received with derision by the literary law givers. The only exception was a note from Ralph Waldo Emerson.

[text crossed out] in 1857 a second issue, a very neat $16 \mathrm{mo}$. volume of 384 pages, was published in New York, containing thirty-two poems.

The [text crossed out] third issue, containing, large and small, one hundred and fiftyfour poems, superbly printed, (it is indeed universally pronounced, here and in England, a perfect specimen of choice typography,) came forth in Boston, the current year, 1860.

Such is the book to which this curious collection of criticisms refers. The poem itself, (for Leaves of Grass, all have a compact unity,) may be described, in short terms, as the Song of the sovereignty of One's self-and the Song of entire faith in all that Nature is, universal, and particular - and in all that belongs to a man, body and soul. The egotistical outset, "I celebrate myself," and which runs in spirit through so much of the volume, speaks for him or her reading it precisely the same as for the author, and is invariably to be so applied. Thus the book is a gospel of self-assertion and self-reliance for every American reader-which is the same as saying it is the gospel of Democracy. 
A man "in perfect health" here comes forward, devoting his life to the experiment of singing the New World in a New Song-not only new in spirit, but new in letter, in form. To him America means not at all a second edition, an adaptation of Europe-not content with a new theory and practice of politics only - but above its politics, and more important than they, inaugurating new and infinitely more generous and comprehensive theories of Sociology, Literature, Religion and Comradeship.

We therefore do not wonder at the general howl with which these poems [text crossed out] have been received both in America and in Europe. The truth about the [text crossed out] and its author is, that they both of them confound and contradict several of the most cherished of the old and hitherto accepted canons upon the right manner and matter of men and books - and cannot be judged thereby;-but aim to establish new canons, and can only be judged by them. Just the same as America itself does and can only be judged.

Neither can the song of Leaves of Grass ever be judged by the intellect-nor suffice to be read merely once or so, for amusement. This strange song, (often offensive to the intellect), is to be felt, absorbed by the soul. It is to be dwelt upon-returned to, again and again. It wants a broad space to turn in, like a big ship. Many readers, [text crossed out] will be perplexed and baffled by it at first; but in frequent cases those who liked the book least at first will take it closest to their hearts upon a second or third perusal.

Permanency is written all over the poem, so far. Also, a peculiar native idiomatic flavor is in it, to many disagreeable. There is no denying, indeed, that an essential quality it takes from its author, is, (as has been charged,) the quality of the celebrated New York "rough," full of muscular and excessively virile energy, full of animal blood, masterful, striding to the front rank, allowing none to walk before him, full of rudeness and recklessness, talking and acting his own way, utterly regardless of other people's ways.

The cry of indecency against "Leaves of Grass" amounts, when plainly stated, about to this: Other writers assume that the sexual relations are shameful in themselves, and not to be put in poems. But our new bard [text crossed out] assumes that those very relations are the most beautiful and pure and divine of any - and in that way he "celebrates" them. No wonder he confounds the orthodox. Yet his indecency is the ever-recurring indecency of the inspired Biblical writers - and is that of innocent youth, and of the natural and untainted man in all ages.

In other words, the only explanation the reader needs to bear in mind to clear up the whole matter is this: The subjects [text crossed out] about which such a storm has been raised, are treated by Walt Whitman with unprecedented boldness and candor, but always in the very highest religious and esthetic spirit. Filthy to others, to him they are not filthy, but "illustrious." While his "critics," (carefully minding never to state the foregoing fact, thought it is stamped all over the book,) consider those subjects in Leaves of Grass, from the point of view of persons standing on the lowest animal and infidelistic platform. Which, then, is really the "beast?"

Those who really know Walt Whitman will be amused beyond measure at the personal statements put forth about him in some of these criticisms. We believe it was Dr. Dictionary Johnson who said that persons of any celebrity may calculate how much truth there is in histories and written lives by weighing the amount of that article in the stuff that is printed about themselves.

The notices, \&c., in this supplement, from pages 3 to 64 , refer in their allusions to the typography, \&c., to the first and second issues of "Leaves of Grass." The paper, print, and binding of the present edition of the Thayer \& Eldridge have, as we before said, received, as they deserve, unconditional applause. 


\section{LEAVES OF GRASS (1867)}

\section{"Walt Whitman." The London Review and Weekly fournal of Politics, Society, Literature, and Art (June 8, 1867), 641-643.}

So far as the title-page of the well-printed volume before us furnishes any information, it is written by and published by New York, and doubtless such is the case. We understand it to be a collection of Walt Whitman's previous works, "Leaves of Grass," and "Drum-taps," with the addition of a work containing much that has not been before printed, entitled "Songs before Parting." A careful perusal of these remarkable productions has convinced us that the vague impression we have now and then encountered that Walt Whitman is a kind of "learned pig" is far from correct; we cannot pretend to name his species exactly, but it is certainly winged. That there is genius in these poems is unquestionable; yet it is difficult to assign their author any place in literature, unless, indeed, one may assume the veracity of metempsychosis, and say that here is Hafiz again, only drunk now with Catawba wine instead of the Saoma, and worshipping the Mississippi river instead of the Saravati, which, having dried up in Persia, may be supposed to have also transmigrated westward. ${ }^{33}$ Here is the lofty optimism of Hafiz preferring dust-grains to pearls, and his audacity believing that he will gain Paradise only by not shunning hell. And indeed there are some poems of Whitman's in which he seems to yearn towards the East from a westward outlook, as if he were more akin to it than to what America has inherited from Europe. Here is a brief example:-

["Facing West from California's Shores," $L G(1867), 116$.

Nevertheless, the Orientalism of the book is manifestly unconscious, it is really meant to be, and is, intensely American. It is but just, however, to say that the America it celebrates is a transcendental one, related to the world and the distant stars, and not "Uncle Sam's" fenced-in national farm. He sends a health to the world from himself and America-

[Three lines from "Salut au Monde!" LG (1867), 157.]

Comparing this volume with the earlier editions of the "Leaves of Grass" we find that whilst all is retained, including some things that might better have been omitted, there is an entire rearrangement of the pieces, which greatly helps the reader who would find out just what are the central ideas under whose inspiration they have been composed. It is plain that, though the form is often chaotic, the work has a character as a whole. The poems may be classified as celebrations, first, of the individual, and next, of the mass. "My days I sing, and the land's:" this is the key-note. Himself stands for every individual, and America sums up all lands and ages. That universalism which Mr. Hepworth Dixon ${ }^{34}$ found to be the all-pervading element of the Churches and communities of America means much more with Walt Whitman than the future restoration of the wicked, as the following sentences will show:-

[Thirteen lines from "Walt Whitman," LG (1867), 50-53, 57-58.]

When Walt Whitman says en masse, it is always to chant what he claims to be a new theme, only possible to be sung in America, which he calls friendship. He is never weary of celebrating the "love of comrades," the "boys together singing," the friends" "hand in hand." This is the soul of democracy. Here is his "Song":-

[All lines except the opening line of "A Song," LG (1867), 125-126.]

He dreams a dream of "a city invincible to the attacks of the whole of the rest of the earth," which is the new City of Friends; and he calls East, West, North, South, to listen to these words:-

[Two lines from "To the East and to the West," LG (1867), 141.] 
There is in these poems fullness of expression for clear and vehement convictions; a stateliness of both thought and language; an innocent forgetfulness of all conventionalities; an unconscious nakedness of images; pictorial words without any of the usual poetic conceits and metaphors. There are also swamps and deserts to be passed through, and long stretches of the names of places and occupations which are evidently condensed poems to the author, but which become as hard to get over as Brighton shingles to the ordinary reader. ${ }^{35}$ It has, indeed, something of the vastness of the succession of objects in nature, as a forest or savannah, but one does not like to get lost even in forest sublimities. Nevertheless, we have no apprehension that any one with eyes who shall read this volume, will fail to place a very high value upon it. Much has been said of its coarseness. There are, indeed, a few-a very few-portions of it which are coarse, and there are others which, without being coarse, are plain-spoken to a degree not generally permitted to contemporaries, though sometimes praised in ancient books. Whatever may be said of the passages to which we refer, this at least should we say, that they are not written in any defiant or destructive spirit.

We may notice here that among the young Americans whom this strange poet or prophet has inspired, one, Mr. John Burroughs, has written an interesting account of him, the advance sheets of which a friend has kindly placed in our hands. The following extracts will doubtless interest our readers:-

[Four paragraphs probably from proof sheets for Notes on Walt Whitman.

However, the paragraphs must have been drastically revised in proof.]

We feel a certain responsibility in alluding to this strange work; but there is that in it, with all its eccentricity and vagueness, which removes it from the category of common-place books, and places it among those of which a critic is bound to give a fair and impartial account. It is unfortunate that this odd poet should have spoiled so much beautiful work with even one smear of nastiness; but however we may regret his having done so, we cannot afford to lose what he has given us because he has not given it in a purer spirit. $\mathrm{He}$ is far more chaste than Mr. Swinburne, whom he resembles in many particulars he is not more irreverent than Shelley; he is in some points more dramatic than either, and far less hurtful. There is a wild, natural exuberance of animalism displayed by Whitman of a thoroughly original kind, an open-air abandonment, a weird and exalted receptivity embracing the good and the bad, the vice and the virtue of life, with a power and comprehensiveness as striking as it is novel. If he will but learn to tame a little, America will at last have a genuine American poet.

We are not defending Whitman's audacity, nor maintaining that a poet may run counter to every social and religious belief and law, because he is a poet; but genius is too rare and too precious a gift to the world to be lost and forgotten simply on the score of its raving at times. Besides, Whitman removes grossness out of the reach of passion, renders it completely unsuggestive or alluring by his uncovered and unornamented distinctiveness. We have read leading articles in newspapers far more subversive of nicety in modest thought than the worst of Whitman's erotics, if erotics we can term his rhapsodical worship of form and flesh. At the same time Whitman is not a poet for the family circle, nor is his book one which could be allowed into everybody's hands. Taking "Leaves of Grass" on the whole, we have no hesitation in pronouncing them to be leaves containing noble and sublime images-leaves in which there is a throbbing and real pulse of that great sympathy which indicates the poet, and for which we are disposed to forgive a taint of earthiness and mould which may in a future edition be removed.

\section{Other newly discovered reviews:}

“The Observer.” Massachusetts Weekly Spy 95:44 (November 2, 1866), 1. W[illiam] D[ouglas] O'C [onnor]. "Walt Whitman." New York Times (December $2,1866), 2$. 


\title{
POEMS BY WALT WHITMAN (1868)
}

\author{
"The Poetry of the Period. The Poetry of the Future." Temple Bar (Oc- \\ tober 1869), 314-327.
}

Many people will, we daresay, be surprised to find that we have not yet exhausted the Poetry of the Period, and still more astonished at our placing in that category the "Poetry of the Future." But have they not heard of the "Music of the Future;" ${ }^{36}$ and not only heard of it, but heard it? It is not a thing promised, but a thing accomplished. The foundations of it at least are laid; and even these are pronounced by its prophets to be already superior to the highest summits ever attained by such puny composers of the past as Mozart, Handel, and Beethoven. So is it with the Poetry of the Future. It consists of no merely prophesied strains: the first singer of it is here and amongst us, and his previous productions are to be had at the circulating libraries. True, he is only the first of a long succession of coming bards; but these will follow in his footsteps, as Virgil is said to have trodden in those of Homer, Dante in those of Virgil, Milton in those of Dante, and so on through the sustained inheritance of song. If, as has been seen, we are not overwell satisfied with such productions of the muse as are vouchsafed us by living English bards, we have no reason to distress ourselves, or even to cast fond eyes upon the bygone days of a happier poetical literature, in order to find consolation. We must look forwards, not backwards. Not Byron and his predecessors, but Mr. Walt Whitman and his successors, constitute the balm that still abides in Gilead. The Old World is done up, no doubt; but Apollo has taken refuge in the United States. The pottering little fountain of Hippocrene, now run dry, has been replaced by the tremendous waters of the everlasting Mississippi, and the Parnassian and Heliconian ranges have abdicated in favour of the Alleghanies and the setting sun. ${ }^{37}$

That our readers may not think we are setting up imaginary claims, we must beg to be permitted to lay before them the proofs of their existence; and we have less scruple in doing so, as we fancy we have in store for them no mean entertainment. To some of them the name of Mr. Walt Whitman will be faintly familiar; but to others, and indeed the majority, we imagine it will represent nothing at all. It is highly desirable that they should become more intimately acquainted with a gentleman who, both through his own voice, and (as we shall shortly see) through the voices of some exceedingly wellknown English admirers, affects to be doing so much for the present and future literary greatness of the human race.

Mr. Walt Whitman was incited to compose the various poems, from which we will make copious citations as we proceed, by a contempt for the Poetry of the Period; and it is obvious that he, therefore, has a special claim upon our attention. His opinion of it is, that it is either "the poetry of an elegantly weak sentimentalism, at bottom nothing but maudlin puerilities, or more or less musical verbiage, arising out of a life of depression and enervation as their result; or else that class of poetry, plays, \&c., of which the foundation is feudalism, with its ideas of lords and ladies, its standard of gentility, and the manners of high life below stairs in every line and verse." From him we are to expect no such feminine and frivolous stuff; he is as masculine-again another reason for our examining his pretensions - as any of us, sick of the feminine twang of other lyres, can possibly desire:-

[Three lines from "Starting from Paumanok," Poems by Walt Whitman, 85.] 
He is declared by one of his most ardent admirers, Mr. W.M. Rossetti-to whom we shall have to revert more than once in this paper, and who is esteemed, by a select but somewhat notorious circle, a mighty authority in poetical matters - to "occupy at the present moment a unique position on the globe, and one which, even in past times, can have been occupied by only an infinitesimally small number of men. He is the one man who entertains and professes respecting himself the grave conviction, that he is the actual and prospective founder of a new poetic literature, and a great one - a literature proportional to the material vastness and the unmeasured destinies of America. He believes that the Columbus of the Continent, or the Washington of the States, was not more truly than himself the patron and founder and upbuilder of this America." [. . . ]

Such being the case, let us boldly look this bold man in the face, and see what he is like; for if he really be not only of the order of great poets, but the founder of an absolutely new school of poetry, evidently he is a pearl beyond all price. His fundamental notions of poetry are, we must confess, for the most part correct. "The direct trial of him," he says in his preface to "Leaves of Grass," "who would be the greatest poet, is to-day. As if it were necessary to trot back generation after generation to the Eastern records!"We have ourselves so strongly insisted on this point, that we need scarcely say we cordially agree with the sentiments thus expressed. The trial of the great poet is undoubtedly today. We, however, have asserted in no doubtful terms that the trial is too great, and that to-day has produced and can produce no great poet. Mr. Whitman says it can and has, and he is the great poet it has produced. The present age has broken with the past, and he has done the same; and he is the great poet of to-day, and the founder of the great Poetry of the Future.

[Seven lines from "Starting from Paumanok," Poems by Walt Whitman, 69, 81, 85.]

Mr. Whitman then sings of to-day, and does so of set purpose - a purpose with which we should heartily sympathise if we did not feel the profound conviction that doing so is only lost time. The next question is, What does he see in to-day to sing? He sees four things: namely, America, Democracy, Personality, and Materialism. These for him are the subjects of song both in the present and the future; and he would be a bold man who would deny that, if to-day be the trial of a great poet, these four things may, if not must, properly constitute the great poet's themes. Let us see what he has to say concerning each of them in succession.

The references to America - its greatness, bigness, wonderfulness - in Mr. Whitman's "Poems" are incessant; and certainly the glory of one's country has ever been deemed a worthy subject for the muse:

[Ten lines from "Starting from Paumanok," and four lines from "American Feuillage," Poems by Walt Whitman, 69-71, 73, 88.]

And so on, through pages of what Mr. Rossetti calls "the first order of poetry." We need scarcely load our pages with quotations from well-known poets on the subject of their country; we think we may rest content to say that, if the foregoing be poetry at all, all that Virgil, Horace, Ovid, and Lucan have written about Rome-all that Dante, Petrarch, Tasso, and Alfieri have written about Italy - all that Scott and Burns have written about Scotland-had better be flung into the dusthole and forgotten. ${ }^{38}$ In his preface to "Leaves of Grass," Mr. Whitman informs us that "the United States themselves are essentially the greatest poem;" and farther on, in the same production, he declares that "of all nations, the United States, with veins full of poetical stuff, will doubtless have the greatest poets"-he himself being, as we have seen, the forerunner and first of them. All this, as anybody can perceive who possesses an atom of penetration, arises simply from Mr. Whitman's admiration of bigness - which he mistakes for greatness - attempting to carry it on his shoulders, and staggering under it most woefully. In fact, all the quotations we have as yet made from his "poems" - and we have so far quoted only the most 
rational of them - will, we fancy, strike our readers as resembling more what they will imagine must have been the improvising of savages in their literary moods before (if we may be pardoned the bull) letters were known at all.

[Four lines from "Starting from Paumanok" and three lines from "American Feuillage," Poems by Walt Whitman, 87, 93-94.]

We confess we think the picture not an inaccurate one. Mr. Walt Whitman screaming, and with wings slowly flapping, realises our notion of him in his poetical condition - this Gull of Mississippi, as opposed to the Swan of Avon-as perfectly as language could well present it to us. ${ }^{39}$

In connection with this wild inarticulate worship of America must be noticed Mr. Whitman's attempts at what may be called Universality. It is one of the tricks of our time, and, as a matter of course, he is infected with it. Unable, just like many of his somewhat less boisterous contemporaries, to understand the vast problem presented by the past, present, and future of the world, like them again he fancies he has solved it by a clumsy application of the Bene quodcunque est doctrine.$^{40}$ Here is his way of expressing himself on the subject:

[Seven lines from "Antecedents," Poems by Walt Whitman, 133-134.]

It is just possible that some people will find this assuring; but we should vastly like to see the person who thinks it poetry, let alone "the highest order of poetry." In one of his "poems," called "Salut Au Monde," he gets hold of the atlas, enumerates nearly every spot on the face of the globe, and says that he sees, hears, and belongs to it. It is done in this fashion:

[Six lines from "Salut Au Monde!" Poems by Walt Whitman, 146.]

And so on, varied by "I see," "I hear," "I behold." But he goes still farther than this. His "Universality" embraces not only all places, but all persons, and everything they can do, good, bad, or indifferent:

[One line from "City of Ships," two lines from "Visages," and five lines from

"Starting from Paumanok," Poems by Walt Whitman, 201, 277, 74.]

There is much more to the same effect which we cannot possibly quote; but when we add that he avers ugliness to be as welcome to him as beauty, and declares, on one occasion, "I will sleep with the cleaners of _ _ " (there is no blank in the original), a fair notion of Mr. Whitman's poetical universality-springing from and invariably returning to the central notion that everything either is America or has been made for it - has been obtained by the reader.

America thus being the very stock-in-trade of his compositions, democracy, as a matter of course, comes in for considerable glorification, after the author's tumultuous fashion:

[Six lines from "Starting from Paumanok," Poems by Walt Whitman, 78-79.]

A story is told of a countryman of Mr. Walt Whitman, who, after reading Mr. Tennyson's "In Memoriam," passed on it the not inapt criticism, "What on airth is the use of screaming against the calm facts of creation?" Mr. Whitman evidently thinks that at any rate, there is a good deal of use in screaming for them. He wishes to see democracy screaming too:

[Three lines from "The Uprising," Poems by Walt Whitman, 185.]

Borne almost beyond himself, he in one place exclaims:

"Bully for you! you proud, friendly, free Manhattanese!"

But, of course, all Americans are equally proud, friendly, and free, and every one of them is just as proud, friendly, free, and everything else, as every other:

[Three lines from "To Working-Men," Poems by Walt Whitman, 104.]

One more quotation, and we will leave this second theme of Mr. Walt Whitman's:

[Two lines from "Song of Sunset" and three lines from "So Long!," Poems by Walt Whitman, 398-399.]

His glorification of the individual, or Personality, as he himself loves to call it, is nearly 
as frequent, and to the full as conspicuous. He never alludes to subordination or coordination; he knows them not. The doctrine of Pope, that:

"Order is Heaven's first law; and, that confessed,

Some are and must be better than the rest;" 41

or that of Shakespeare:

"Take but degree away, untune that string,

And mark what discord follows" _42

are unknown to him; or, if they are known, he utterly contemns them. As he says, he sings the Equalities, with a large E.

"I will effuse egotism, and show it underlying all — and I will be the bard of personality."

Sometimes he glorifies it in himself, sometimes in another, sometimes in himself and another together:

[Two lines from "To a Pupil," Poems by Walt Whitman, 34; five lines from "Walt Whitman," two lines from "Starting from Paumanok," and four lines from "Me Imperturbe," $L G$ (1867), 318; three Whitmanesque lines not from any identifiable source.]

And, as a matter of course, You doing the same thing, and occupying the same proud position!

We now arrive at the fourth of the main themes whose glories Mr. Walt Whitman and his admirers consider that he is specially commissioned to sing, or (as he himself expresses it) to "yawp over the roofs of the world."We mean-Materialism. We are informed, by one of the many curiositymongers who have busied themselves with Mr. Whitman's private habits - with which we have nothing to do-that he is exceedingly communicative on all subjects save one. If interrogated as to his theological opinions, he turns dead silent. In his compositions, however, he is garrulous enough upon the subject, and, some will think, rather contradictory. We are not of that opinion. It is true he speaks continually of the Soul; but then there is, we should imagine, no word in the language capable of a vague signification, and of being commenced with a capital, that does not find its way into his tumultuous tossing together of the component parts of the dictionary. How far he understands the Soul in any recognized acceptation of the word, our readers will judge for themselves, when they have seen a few of his utterances on the subject:

[Five lines from "Starting from Paumanok," Poems by Walt Whitman, 80-81.]

With him this is a rooted conviction. He says that he is "divine inside and out," and with a license of language - which is a mere nothing to what he often indulges in, but which in this instance makes us lose our sense of profanity in an irresistible peal of laughter-he assures us that "the scent of these armpits is an aroma finer than prayer!" If he worships any particular thing, he says it shall be "some of the spread of my own body." One long passage commences thus:

[Ten lines from "I Sing the Body Electric," LG (1867), 106-107.]

It must not be supposed we have quoted the entire passage. We dare not, even if we had space. Suffice it to say that the enumeration covers two long pages, and that, physiologically speaking, it is exhaustive. Nor is his admiration confined to the human body:

[Three lines from "To Working-Men," Poems by Walt Whitman, 112-113.]

As a concluding and crowning embodiment and expression of Mr. Whitman's Materialism, let us take the following:-

[Three lines from "Starting from Paumanok" and two lines from "Starting from

Paumanok," Poems by Walt Whitman, 72, 110.] [. . .]

Such, then, being the opinions which, it must be presumed, some people in these strange days entertain, since they express them, of Mr. Walt Whitman's literary claims, we think it right, if only to liberate our souls - and we should imagine those of most of our readers - emphatically, but in all serious calmness, to declare, on the contrary, our 
opinion, that his style has nothing in common with either the Bible, Shakspeare, Plato, or any other hitherto honoured name in literature; but that his grotesque, ungrammatical, and repulsive rhapsodies can be fitly compared only to the painful ravings of maniacs' dens.

Such, however, is the Poetry of the Future? Perhaps it is. If so, we must console ourselves by reflecting that, unsatisfactory as may be the Poetry of the Period, if we had been born a generation later still, our poetical plight would have been yet worse than it is. Yet we shrewdly suspect that one is the child of the other. Mr. Whitman himself distinctly says that it is. As we have already stated, he informs us that he was urged to lay the foundations of the Poetry of the Future, because, in his opinion, that of the Period is "the poetry of an elegantly weak sentimentalism, at bottom nothing but maudlin puerilities, or more or less musical verbiage" - in a word, because, as we ourselves have been urging in those papers, it is deficient in all masculine and lofty qualities. Mr. Whitman revolts against it; and his is a revolt with a vengeance. Mr. Tennyson and his admirers have been fancying that they had swept and garnished the Halls of Literature, got rid of all such objectionable robustness as figures in the verse of Shakespeare, a Byron, or a Burns, and made the place sweet, trim, and pretty for all time. But, alas! seven devils worse than the first have entered, and its state promises to be more terrible than ever. Nor are we sure that there is not a good deal of truth in what Mr. Whitman says of the same school of poetry being based on a now extinct feudalism, and on standards of gentility belonging to a somewhat later period. At any rate, he will have none of these. As Mr. Rossetti reminds us, it has been said of Mr. Whitman by one of his warmest admirers, "He is Democracy." We really think he is - in his compositions, at least; being, like it, ignorant, sanguine, noisy, coarse, and chaotic! Democracy may be, and we fear is, our proximate future; and it will, as a matter of course, bring its poetry along with it. The prospect is not an agreeable one; but, as a protection both against it and our present condition, we can always fall back upon the grand old masters of the Past, from whom it is quite certain that singers, whether insipid or insane, will never succeed in weaning the healthy opinion of mankind.

\section{“American Poets. Second Part.” Dublin Review [n.s.] 23:45 (July 1874), 64-86.}

We endeavoured in our last number to show the natural advantages possessed by American poets, and the clear reflection of national scenery to be found in their works. We traced the rise of American poetry, and passed briefly in review the writings of Mrs. Sigourney, the chief poetess of the United States, of the classical William Cullen Bryant, the Catholic aspects of Longfellow, the Quaker-like purity of Bayard Taylor's verse, the Catholic poetry to be found in periodicals, and the moralizing humour of Oliver Wendell Holmes. Resuming our subject at the point where we were obliged to break off, we now proceed with our intended sketch of those poets in America who have distinguished themselves most highly in their own country, and have the best claim to be welcomed in ours. [...]

It is now nearly twenty years since Walt Whitman's "Blades of Grass” were first published, and as they have undoubtedly exercised a wide and lasting influence, notwithstanding their peculiar form, we feel bound to submit them to a careful analysis. Mr. William Michael Rossetti was principally concerned in introducing his works into the English market; and when it is remembered that Mr. Rossetti is the bosom friend of Swinburne, our readers will not be surprised to hear that Walt Whitman, as an author, is the embodiment of all that is most opposed to the Catholic religion. It is curious also 
to observe that Mr. Rossetti's first estimate and admiration of the works of this poet appeared in the Chronicle for July 6, 1867, under the article "Walt Whitman's Poems." In consequence of this article, as he himself informs us, he was requested to edit a selection from Whitman's writings. Happily these poems, or Ossianic effusions, fraught with the most dangerous principles, do not come before the world in an attractive shape. A certain rhythm runs through them, but they have no rhyme, except in a few instances, nor are they even in blank verse. They are far less poetic in form than the Psalms and Prophets in Hebrew, or Southey's "Thalaba the Destroyer," and may be regarded, as some one has said, "as a warp of prose amid the weft of poetry." 43 Thus even in composition, they are but a mongrel breed - a hybrid monstrosity. For this reason indeed, Walt Whitman has adopted his strange attire. It strikes the eye; it imposes by its novelty; it bespeaks the audacious personality of the man himself. He claims to be the man of the period-the voice of Republican America. His claim is admitted by his admirers. He cannot be dealt with as a child or a fool. He is neither. He is the exponent of democracy; the champion of humanity; the nineteenth century incarnate. Man, individual and en masse, that is his theme. For him, evil has no existence, or if it exists, it is well that it should exist.

[Two lines from "Starting from Paumanok," Poems by Walt Whitman, 74.]

His grandfather was "the great Quaker Iconoclast, Elias Hicks," and as dispositions of mind and body are alike hereditary, we find in the grandson an Iconoclast of another type. Whitman's ambition is to break into pieces every sacred image and construct a theory of humanity entirely his own. That his enthusiasm is genuine may be inferred from the fact of his devoting himself to the care of the sick and wounded, in the field and in the hospitals, during the Civil War between the North and South. It is not, however, the less to be dreaded on that account. Benevolence and Atheism were combined in Shelley, and so are self-sacrifice and Materialism united in Walt Whitman. He was in advance of his time, as to his new doctrine, when he first wrote, and though his materialistic ideas have now become far more common, he is in some respects in advance of his time still. The day of his influence, therefore, is not over, for he is more logical than many of his fellows, and carries out their notions into results from which they themselves would perhaps recoil. He is come, this Auguste Comte in verse, this demolisher of all religion, to "inaugurate a religion." They are his own words.

[Eight lines from "Starting from Paumanok," Poems by Walt Whitman, 75.]

There is vigour and power enough here, and truth too, if the words were interpreted in a right sense, but whether these long, wavy "Leaves of Grass" deserve, as poetry, the praises lavished on them by Messrs. Emerson, Rossetti, and Swinburne, we leave to our readers to judge. It is more to our purpose to inquire what is the "greater religion," the germs of which Walt Whitman dropped into the earth. It is not, you may be sure, the Catholic religion, nor is it Christianity in any sense, though the Bible is one of the writer's favourite books. It is, as nearly as it may be described, the Religion of Humanity - the religion for which Mazzini fought with the pen and Garibaldi with the sword. ${ }^{44}$ You may infer what it is from a passage in the Preface to "Leaves of Grass" written by the poet himself:-

["Preface to the First Edition of Leaves of Grass," Poems by Walt Whitman, 60-61.]

Though this passage is printed as prose, it is quite as much poetry as the "Leaves of Grass." It represents the ideas of Comte as developed in his "Positive Religion." " 5 Yet it must not be supposed that Walt Whitman is a plagiarist in any sense. He does not strictly follow Comte, Mazzini, Victor Hugo, Huxley, or Tyndall, though he may by accident agree with each of them in turn. ${ }^{46}$ His system, with its rotten basis, its hideous defects, and its strange admixture of the beautiful and the grand, is all his own. Materialist though he be, to such an extent as to make matter in general, and our bodies in particular divine, he is not a pure materialist; he teaches the immortality of the soul and the body, and in 
his poems, as by the bedside of the dying, he predicts with the confidence of faith the existence of the soul after death clothed in a finer frame of matter elaborated within us during our earthly life. This is, we believe, a doctrine of many Spiritualists; but Whitman is not properly a Spiritualist any more than a mere Materialist. When we consider the breadth of his system, and the multitude of beautiful truths he has incorporated into it, we cannot but deeply lament that, either through perversity or defective education, or both, he has not been intromitted into the glorious heritage of the Catholic faith, where he would find all that he now holds of good and true under the seal of the Blood of an Incarnate God, to the exclusion of all that he holds also which is earthly, sensual, and devilish. For him, as for Catholics, but under very different conditions, the air around is full of spirits released from their mortal coil. Yet with this and similarly sublime and consoling reflections, he associates occasionally passages and entire poems so corrupt in morals and so indecent in language that they are omitted in English editions of his works. With Whitman, the body is the soul, and the soul is the body; the corpse that we drop in the grave is "excrementitious"; the real body survives:

[Two lines from "Starting from Paumanok," Poems by Walt Whitman, 81.]

It is the soul-body of which he speaks, the magnetic or ethereal body, supposed by some to be formed and still forming within the grosser body which will die. If Whitman could be described in one word, we should call him a Universalist. He has no antagonisms. He accepts all, admires all, loves all. He would embrace all objects, material and spiritual, as if the grasp of his finite intellect were the underlying principle that welds things together, harmonizes all discords, annihilates all distinctions of good and evil, of pain and pleasure, of past and future, time and eternity:-

[Seven lines from "Antecedents," Poems by Walt Whitman, 133-134.]

If in this place we were discussing systems of philosophy in the United States instead of poetry, it would be necessary to enter more fully into the subject of Walt Whitman's speculations. He is not a mere rhapsodist, nor can he be dismissed as a dreamer or an imbecile. There is more bone and sinew in his pages than in those of any other American poet, and that mainly because his ideas are often new and always daring. But enough has been said here for the guidance of those who are curious about his school of thought, and we must make but one further remark on his character as a poet. Of all American poets he is the most intensely national, and in him the great Democracy of the West has found a man who, as Carlyle says, "will speak forth melodiously what the heart of it means." 47 $\mathrm{He}$ has given scope to the gigantic ideas of his people, and to their unparalleled activity and progress in every social and scientific department. His verses, like his genius, are shaggy and unshorn, and they shake the land like a herd of buffaloes thundering over the prairie. Nothing more national than his "American Feuillage," "Drum Taps," and poems on the death of President Lincoln, was ever written; and deeply as we deplore the erratic path into which his eager mind has wandered, we cannot but recognize in his talents a gift of the Most High, and in his writings much that is beautiful and precious in the midst of much that is dangerous and base. Any study of American poetry which did not embrace his works would be imperfect, because he has given it a direction in the line of original and powerful thought. If the Catholic religion should spread more widely in the United States, and obtain a firmer hold, directly or indirectly over the public mind, the divine alchemy of which they are possessed who "have the unction from the holy One and know all things" might turn much of his alloyed metal into refined gold. ${ }^{48}$ Fresh and athletic poetry was what, before Whitman's time, America wanted; and now that the want has in some degree, and under great disadvantage, been supplied, it only remains to impart to the new importation that religious and Christian character which made Dante and Milton rulers in the realms of mind. It is, doubtless, by permission of the All-Wise that poets as well as professors, in America as in England, are ranging themselves with new energy in the ranks of unbelief; but it will be, as ever, the sublime 
office of the Catholic Church to strike the weapons from their hands, to enrich herself with their spoils, and to yoke them to the triumphant car of him who cometh with dyed garments from Bosra. ${ }^{49}$

Having said this much of Walt Whitman's compositions, and believing, as we do, that in matter of poetry they represent the American mind and the state of American society more faithfully than any other poems - shadowing forth with a certain wild magnificence the rapid, gigantic, and terrible growth of principles false and true-we ought perhaps to give a further specimen of the strange long sweep and Hebraic recurrences in the verse of this thorough Yankee:-

[Thirty-two lines from "Miracles," Poems by Walt Whitman, 275-277.] [. . .]

\title{
Other newly discovered reviews:
}

"Poems by Walt Whitman." The New Eclectic (1868), 371-375.

"Walt Whitman." Once A Week (June 1, 1872), 501-505.

\section{AS A STRONG BIRD ON PINIONS FREE (1872)}

\author{
"Recent Literature" ["After All Not to Create Only"]. Atlantic Monthly \\ 29 (January 1872), 108-109.
}

\section{LEAVES OF GRASS (1871-1872)}

\section{Peter Bayne. "Walt Whitman's Poems.” Contemporary Review 27 (De- cember 1875), 49-69.}

The critic who calls our attention to true poetry does us one of the best possible services; for no imagery derived from the beauty or the bounteousness of nature-from golden islands of the sunset or pearly dews of dawn, from corn, or wine, or glowing fruit-can express too strongly the goodliness of poetry that is really such; but in proportion to the gracious beneficence of this service is the maleficence of critics who, by their wit or their authority, beguile us into reading atrociously bad verse. If I ever saw anything in print that deserved to be characterized as atrociously bad, it is the poetry of Walt Whitman; and the three critics of repute, Dr. Dowden, Mr. W. Rossetti, and Mr. Buchanan, who have praised his performances, appear to me to be playing off on the public a well-intentioned, probably good-humoured, but really cruel hoax. I shall state briefly what I found the so-called poetry to be, presenting a few samples of Whitman's work: if these are such as the English public will regard with any other feelings but scorn and disgust, I for one have mistaken the character of my countrymen.

The "Leaves of Grass," under which designation Whitman includes all his poems, are unlike anything else that has passed among men as poetry. They are neither in rhyme nor in any measure known as blank verse; and they are emitted in spurts or gushes of unequal 
length, which can only by courtesy be called lines. Neither in form nor in substance are they poetry; they are inflated, wordy, foolish prose; and it is only because he and his eulogists call them poems, and because I do not care to dispute about words, that I give them the name. Whitman's admirers maintain that their originality is their superlative merit. I undertake to show that it is a mere knack, a "trick of singularity," which sound critics ought to expose and denounce, not to commend. [. . .]

If the necessity of being original lies hard upon poets in these days, is it not all the more, on that account, the duty of critics to press upon them the equally inexorable necessity of resisting the fascinations of false and affected originality? Novelty is essential to art; every genuine art-product, in sculpture, in painting, in poetry, is unique: but it is intensely untrue that everything that is novel and unparalleled is art; and so easy is it to ape or to travesty right newness, that Whitman's conscious and trumpeted purpose to produce something original ought to have been, in the eyes of critics so acute as Dr. Dowden and so accomplished as Mr. W. Rossetti, a presumption that the originality forthcoming would be spurious. Every art-product is new, but every art-product is also old; and the operation of producing a true poem or picture-an operation too subtle to be described in words or executed by rule-consists essentially in combining newness of form and colour and musical harmony with oldness of principle and law. An illustration of this union, applicable, to my thinking, with scientific accuracy to the case in hand, is afforded by nature every spring. When the brown hill-side breaks, as Goethe finely says, into a wave of green, every hollow of blue shade, every curve of tuft, and plume, and tendril, every broken sun-gleam on spray of young leaves, is new. No spring is a repetition of any former spring. And yet the laws of chemistry and of vegetable life are unchanging. The novelty that the poet must give us is the novelty of spring; and the transcendent but inevitable difficulty of poetical originality lies in this, that the limits of variation within which he is permitted to work are narrow. His poetry must be as different from that of any other poet as one spring is different from another; but it must not be more so. It is a fundamental principle, laid down by that ancient nation which was inspired to write the bible of art, that all gigantesque, eccentric, distorted, extravagant art is barbarous. By working in the spirit of the lesson taught it once and for ever by Greece, Europe has gone beyond Greece; but as far as Europe, in Shakespeare, has transcended Greece, so far will America fall behind and below not Europe only, but Egypt, Babylon, and Assyria, if she casts the lesson of Greece to the winds and consent to the identification of democracy with lawless extravagance. It would, I believe, be unfair to the Americans to speak of them as pledged to admiration of Whitman. They are not afraid to give everyone a hearing, and in this they are bravely right; but they have a way, also, of getting, sooner or later, at the true value of a man, and I rather think they have found Whitman out. I have produced abundant evidence to prove that he exceeds all the bounds fixed to sound poetical originality, and is merely grotesque, and surprising.

It is instructive to note that, whenever Whitman is, comparatively speaking, rational and felicitous, his writing becomes proportionally like that of other people. Of really good poetical work there is, indeed, in those of his poems known to me-and I have read, with desperate resolution, a great deal both of his prose and his verse, including productions which his eulogists specifically extol-very little. Even his best passages have this characteristic of inferior writing, that they deal with sensational subjects and fierce excitements. His lack of delicate and deep sensibility is proved by his producing horror when he aims at pathos. The true masters of pathos obtain their greatest effects by means that seem slight. A Shakespeare, a Goethe, will make all generations mourn over the sorrows of an Italian girl, of a German grisette; a daisy, a mouse, a wounded hare, evoke touches of immortal pathos from Burns. Whitman must have his scores massacred, his butcherly apparatus of blood and mangled flesh, his extremity of peril in 
storm, his melodramatic exaggeration of courage in battle. But it is in the few sketches of such scenes, occurring in the poem called "Walt Whitman," that he is most successful; and then his affectations fall, to a refreshing extent, from his loins, and he makes some approach to the perspicuity, compression, vividness, and force of good writing in general. If his English critics had contented themselves with discriminating between what is passably good and what is insufferably bad in his work, commending the former and condemning the latter, not a word would have been written by me upon the subject. Dr. Dowden, Mr. Rossetti, Mr. Buchanan, and, most vociferously of all, Mr. Swinburne, accept him at his own valuation as "the greatest of American voices," " and the poet of democracy. To do so is to wrong the true poets which America has produced, and to strike a pang as of despair into the hearts of those who, amid all shortcomings and delinquencies, amid Fiske tragedies and Tammany Rings, ${ }^{50}$ refuse to believe that democracy means dissolution, and that the consummation of freedom must be an exchange of the genial bonds and decent amenities of civilization for infrabestial license. Originality, true and clear, characterizes the real poets of America. There is in them a fragrance and flavour native to the American soil, a something that gives them a character as distinctive as marks off the Elizabethans from Milton, or distinguishes Pope and his school from recent English poets. More than this was not to be looked for or desired; the strong presumption was that more than this would indicate monstrosity, debility, or affectation; and this presumption has been verified by Whitman. Nature in America is different from nature in Europe, but we do not, in crossing the Atlantic, pass from cosmos into chaos; and Mr. Carlyle's expression, "winnowings of chaos," poetry if only it were possible to associate with it the idea of any winnowing process whatever. Street-sweepings of lumber-land-disjointed fragments of truth, tossed in wild whirl with disjointed fragments of falsehood-gleams of beauty that have lost their way in a waste of ugliness - such are the contents of what he calls his poems. If here and there we have tints of healthful beauty, and tones of right and manly feeling, they but suffice to prove that he can write sanely and sufferably when he pleases, that his monstrosities and solecisms are sheer affectation, that he is not mad, but only counterfeits madness. He is in no sense a superlatively able man, and it was beyond his powers to make for himself a legitimate poetical reputation. No man of high capacity could be so tumid and tautological as he-could talk, for instance, of the "fluid wet" of the sea; or speak of the aroma of his armpits, or make the crass and vile mistake of bringing into light what nature veils, and confounding liberty with dissolute anarchy. The poet of democracy he is not; but his books may serve to buoy, for the democracy of America, those shallows and sunken rocks on which, if it is cast, it must inevitably, amid the hootings of mankind, be wrecked. Always, unless he chooses to contradict himself for the sake of paradox, his political doctrine is the consecration of mutinous independence and rabid egotism and impudent conceit. In his ideal city "the men and women think lightly of the laws." His advice is to resist much and to obey little. This is the political philosophy of Bedlam, unchained in these ages chiefly through

\footnotetext{
*These words are Mr. Swinburne's, and perhaps could not be endorsed by the others. I take this opportunity of protesting against certain comments made by Mr. Swinburne (in a republished essay on the text of Shelley) on an article written by me for this REviEw in the year 1867. I did not say what Mr. Swinburne represents me as saying, and what I did say can be proved to be grammatically correct. [A. C. Swinburne's discussion of Bayne can be found in "Notes on the Text of Shelley," Fortnightly Review (January/June 1869), 539-562; 557-558.]
} 
the influence of Rousseau, which has blasted the hopes of freedom wherever it has had the chance, and which must be chained up again with ineffable contempt if the self-government of nations is to mean anything else than the death and putrescence of civilization. Incapable of true poetical originality, Whitman had the cleverness to invent a literary trick and the shrewdness to stick to it. As a Yankee phenomenon, to be goodhumouredly laughed at, and to receive that moderate pecuniary remuneration which nature allows to vivacious quacks, he would have been in his place; but when influential critics introduce him to the English public as a great poet, the thing becomes too serious for a joke. While reading Whitman, in the recollection of what had been said about him by those gentlemen, I realized with bitter painfulness how deadly is the peril that our literature may pass into conditions of horrible disease, the raging flame of fever taking the place of natural heat, the ravings of delirium superseding the enthusiasm of poetical imagination, the distortions of tetanic spasm caricaturing the movements, dance-like and music-measured, of harmonious strength. ${ }^{52}$ Therefore I suspended more congenial work to pen this little counterblast to literary extravagance and affectation.

\section{Other newly discovered reviews:}

"Leaves of Grass. Democratic Vistas. The Passage to India." New York Times (November 11, 1870), 2.

George Saintsbury. "Leaves of Grass.” Academy 6 (October 10, 1874), 398400.

\section{TWO RIVULETS (1876)}

\section{"New Work by Walt Whitman." London Daily News (March 11, 1876), 5-6.}

The only American prophet to my knowledge who enjoys a fame in England not accorded him in his own country is the prophet of the new Democratic school of poetry, Walt. Whitman. Although his earlier publications attracted here a certain degree of attention in literary circles, and aroused a great deal of enthusiasm among some of the "plain people," whose singer he especially desired to be called, it can hardly be said that his claims to the rank of poet were seriously considered in America until they had been discussed by Mr. W. M. Rosetti [sic], Mr. Robert Buchanan, and other authorities in London. The dubious position which he won here by their help he has not been able to hold. To-day he probably has ten admirers and readers abroad for every one that he has at home. There is a rough honesty, a wild sort of sweetness in the strange man's character, an evident genuineness in his eccentricities, both personal and literary, which have won for him general respect and even a great deal of popular affection, while the estimate of his poetical powers, accepted a few years ago, has been steadily declining. He is no longer one of the curiosities of the Republic; and while the stories of his extreme poverty and suffering which recently obtained circulation are, I am glad to say, untrue, he has fallen into obscurity, if not into positive neglect, and apparently into a mood of sorrow. The impression which one gathers from a few sheets of his forthcoming volume is at any rate rather a melancholy one. He calls the new book "Two Rivulets," for it contains a stream of prose and a stream of verse: 
[Three lines from Two Rivulets, 15.]

And he sends it out 'partly as my contribution and outpouring to celebrate, in some sort, the feature of the time, the first Centennial of our New World Nationality, and then as chyle and nutriment of that moral and indissoluble union, equally representing all, and the mother of many coming centennials.' Nor is it only in the form of the pieces composing the book that he follows a double line. There are two distinct veins of thought-Politics and Immortality. The rivulets are rude, brawling streams, no doubt, but they keep within much narrower bounds than the turbulent streams of his earlier poems. He has no respect for artificial barriers to poetic inspiration:

["New Poetry," Two Rivulets, 28-30.]

But there is much less than his olden extravagance in this poem, characteristic as it nevertheless is:

["Eidólons," Two Rivulets, 17-20.]

The verses "To a Locomotive in Winter" have perhaps a stronger flavour of the author of "Leaves of Grass":

["To a Locomotive in Winter," Two Rivulets, 25-26.]

Whitman gives his own portrait from life in the book-a large, bending gray-haired man, "looking at you" - and the picture is illustrated by the following verse:-

[Fifteen lines from "Out from Behind This Mask," Two Rivulets, 24.]

And doubtless this is intended as a portrait also:

["When the Full-Grown Poet Came," Two Rivulets, 359.]

I close my extracts from advance sheets of the book with two little pieces of a political character:

["The Beauty of the Ship" and eleven lines from "As a Strong Bird on Pinions Free," Two Rivulets, 247, Annex 3.]

\section{[Walt Whitman?]. "Walt Whitman's Works, 1876 Edition.” The New Republic [Camden, New Jersey] (March 11, 1876), 2.}

Those who have heard that Walt Whitman has become either physically or mentally broken down, or has retired from the contest, or has faltered even for a moment in his plans, will only need to read a very few pages of these volumes, to decide that they have been misinformed. He is here yet, and his style is more daring, more egotistical, more abrupt and involved than ever; he soars more and sings less than ever.

"Leaves of Grass" remains pretty much in the same shape as of yore. The other volume, "Two Rivulets," may be briefly described as a strange alternation of prose and verse, politics and spiritualism. It includes "Memoranda of the War."

But there is nothing in all Walt Whitman's works, new or old, half so marvelous, or half so great a "curiosity of literature" as the steady persistence of the author amid the nearly unanimous opposition (in this country at least) of orthodox criticism.

In this connection, among the items we glean from "interviewers" and others, it is said, we believe authentically, that Whitman has never yet found (and has not today) a publisher for his books, but has always printed them himself, and sold them by agents - that they have a little more than paid their own expenses- that there have been six editions or growths - the magazines scornfully refuse his MSS. - that his heart and spirits are just as cheerful as ever-that he has been ill from paralysis and without income or employment for the last three years (during which also his New York agents have shamelessly embezzled the proceeds of his sales, "which, fortunately," he dryly remarked to the interviewer, who gives us this item, "have not been large") - and that he is now poor, though not in want. 
It may interest some to know that the volumes of this 1876 edition, (a very limited one, less than 150 sets in all,) have each the author's physical touch and magnetism. Every book has been handled by him, contains his signature, and the photograph and pictures put in by his own hands. The newer parts were printed at this office.

Whitman, (P.O. address permanently here in Camden, New Jersey,) sells these books exclusively himself.

Altogether, as he has come through, and as he holds out to-day, he fully illustrates in himself that

"Splendid and savage race of old men"

called for in these pages, in passionate demand for America.

\section{"Walt Whitman, the American Poet." The Evening News (1876[?]), page number unknown.}

Postes nascitur non fit, ${ }^{53}$ if true as applied to the individual, ought on the same principle to be true as applied to peoples, and yet, as a matter of fact, there have been but two really great leading nations in poetry-Greece and Great Britain - and this is perhaps the more remarkable, because, beyond the likeness of both being islanders and born with freedom in their souls as an instinct, their general tone of thought and feeling, and modes of expressing them, were, and are, as dissimilar as could well be between two branches of the same distinctive race of men.

But what is perhaps more remarkable, considering that [an] Anglo-Saxon, when turning colonist, not only takes all his household gods with him into his "fresh fields and pastures new," but also his old stereotyped habits and manners, and that therefore, proportionally to the numbers comprised in his "exodus" to a strange land, would also spring forth in due season poet or poets, as freely in quantity and as great in quality as in the "old land," is the fact that the great Anglo-Saxon "Empire"-in all but name- of the United States has never yet produced one really great poet, although, living as its more energetic sons did, and still do, amidst a newer and far grander variety of wilderness of lake, plain, river, and forest scenery, than their forefathers of the old world did - the natural idea would be that the vastness and freshness of such "untamed nature" would have even educed a yet loftier strain of song, if possible, than their ancient sires of the past, and their old world brethren of the present sang or sing, and yet, instead of this, their highest and their best are barely above mediocrity, or certainly not more than equal to our second-rate English bards!

We suppose by their own valuation at least that "Longfellow" is their best, and yet, when he is at his best, he is not purely American, either in scenery or thoughts, so that their "national poet" not only lacks the power of expression of his mightier European brethren, but his best writings are also deficient in more "local colouring," and so much so that he might almost as well have written most of his works in New South Wales as in New York, as far as mere "tone" goes, only that in that case our Yankee cousins would not have been able to exclaim, like the great sartorial house of Moses and Sons "we keep our own poet on the premises!"

Poietikos, the maker! What a distinctive and expressive name, and yet how few real "makers" are there in the world - plenty of copyists-plenty of mere rhymsters-plenty of authors (?) [sic] with a "fatal facility" for that "easy writing" which, as the wit said, "was such curst hard reading" - but of the real great ones who can boldly and truthfully say, "Alone I did it!" How few, how, for the sake of the whole world, lamentably few there be of them, whose heaven-born gift of seeing farther and clearer into the higher spiritual life, around and about us enables them to pierce the mystery and to seize the esoteric meaning of some real truth, and with utterances of genius, translate it into the 
everyday language of everyday life, and crystallize it as it were, imperishably for all time, to help light up through all the future the lives of the children of men, and show them, as it were, though even as "in a glass darkly" some faint unearthly radiance reflected from the far off dim seen, lustrous splendours of eternity-some shadowy gleam of

"The light that never was on land or sea,

The poet's inspiration and his dream." 54

Truth said the ancient is but of one face, yet hath many features; and so real poetry differs much in its utterance, flowing "sweet as the living waters of Pharpar and Abana," 55 from the one source-mighty and fierce as the thunder falls of Niagara from the other or salt and bitter as the lonely lifeless wave of the Dead Sea of Sodom from a third-and yet all equally "true," and doing the work of truth sooner or later, for truth, like wisdom, is "justified of her children." 56

"Can any good thing come out of Nazareth?" Can a real poet come out of "dollar land?" Can Brother Jonathan prove that he has really "raised" a genuine live poet of his own breed and feed, "clear grit?" and in whose speech speaks unmistakeably the "voice of many waters," the lonely desert, heard in the savage wilds of pathless mountains, and bore secretly and safely through boundless forests, and gave unchanged unto him, to be translated truly from its great mother (nature) tongue, by the mouth of her anointed priest for the teaching of all her children, and for the awakening of new thoughts in the dwellers of older continents and newer colonies.

Whether America herself believes, or does not believe, that she has such a son in Walt Whitman, his English confreres, or at any rate very many of them, do believe that however she may elect to "leave him to his fate" with cold indifference as to his present fortunes, and doubt as to his future fame, yet they cordially recognize him as one of the "deathless band," 58 and as having not only the right to food here but also to fame hereafter, and as there has been some little controversy about him lately on both sides the Atlantic, and as it is possible that none of his works may have fallen into the hands of some of our readers for them to judge either of his merits or demerits, we subjoin a few extracts as well from his own writings as also from what is said and written about him, both by the American and English Press-by statements in which latter it will be seen that whether he ever gains the distinction in the first line or not, he seems to stand a "bad" chance of realising the force and suffering from the ill effects of being driven to practise the second in the well-known couplet-

"Seven Grecian cities claimed great Homer dead,

Through which, in vain, he living begged his bread." 59

Let us, however, hope that the moderns will be both more quickly appreciative and actively charitable than the ancients were, and that bread will at least be found him during the remainder of his mortal life, even though fame may not be given to immortalize him after death.

The apophthegm in physic, "when doctors differ who shall decide?" is also partly applicable to art and taste, and as everything new must have a beginning, the "new beginners" in a new faith, or a new interpretation of art, generally meet with rather a "bad time" of it from the majority whose "faith" or "fancy" they seek to change or supplant, and as Walt Whitman is as "advanced" in some of his ideas about poetry, as Herr Wagner is in his about music, there has been nearly as great a controversy between his few admirers and his many detractors, as to whether his poetry is in any sense poetry at all, and whether it will "live" or not, as there was, and is, about the Herr's "music of the future" as being the possible supplanter, in time, of the melody of the present. ${ }^{60}$

Whether his own countrymen have less "taste" or more judgment, or whether it is on the principle "that a prophet is never honoured in his own country," one thing is certain, that he meets with much more admiration, and, we suppose also, genuine appreciation 
from the British public and republic of letters, than he does from his own republic, and the citizens thereof, dwellers though they be in the same tents with him, and considering how anxious the Americans are to be thought the equals (at least) of the old world in all matter of a[e]sthetics, as well as superiors in enterprise and general intelligence, it is rather surprising that they do not at once accept the dictum of the literary few in England (whose opinion gives a sort of "mint stamp") that they really have a swan where they have hitherto seen only a goose, and (like a shrewd trader when he finds a customer sees a value in his goods more than he dreamt of) at once declare that not only is it a veritable swan, but moreover "a swan amongst swans," and proclaim at once, loudtongued to the old world, that what the "unregenerate" in taste call "roughness" in him is really unhewn rugged strength, the marble block with the Apollo Belvidere strongly fashioned forth in it, ${ }^{61}$ but the smoother chiseling left contemptuously untouched, and the "obscurity of thought and expression" merely the mannerism of one "whose faith is large in time," and who, knowing his work will live, leaves the fuller interpretation of it to the stronger and more advanced minds of the future.

One of his own countrymen (a press correspondent) thus writes of him-

[Two paragraphs from "New Work by Walt Whitman," London Daily News (March 11, 1876), 5.]

There is both force and truth in a good deal of what he then says-for even the poets of all schools admit that rhyme is merely the "colour to the drawing," and that blank verse is the experimentum crucis by which to try all real poetry-in fact, as our readers are aware, rhyme only came into use with the early troubadours, who doubtless found that in an age when "books were not," and their songs were "as household words," that the "jingle" at the end acted as a sort of mental fishhook, and so enabled them to be more easily remembered. Th[e] two oldest and grandest poems in the world, perhaps - the sacred one of "Job," and the secular one of the "Iliad," are in blank verse, or, to speak more correctly, in rhythmical prose, and to rhyme them is not only to ruin them, but is also, more or less, a desecration, even despite Pope's splendid attempt of the one, and because of the miserable "metrical failures" with the other. Also, Whitman is undoubtedly right in this, that inasmuch as "the proper study of mankind is man," so the present should interpret the present, and that there is scope in each age for a great poet to interpret the voice of that special age, and that the "wonders of steam and telegraphy" have as much claim on us, who have helped their Herculean birth, and are profiting by the labours of their giant man-hood, and have as much right to be "sung greatly of" by a great singer, as even the mighty men and things of the mighty past, which yet, after all (however "distance may lend enchantment to the view," and however grandly they may loom out of the depths of the ancient ages, and seem magnified in the dim mists of antiquity,) were not mightier to the men of their day-nor cannot be really mightier to the men of this - than their own mighty present is, with its boundless material power in its thunder throbs of chained and harnessed lightning, and its spiritual strength in the awakening and widening thrills of higher thought and larger life which pulse profoundly through the great living heart of humanity, with a holier purpose, a stronger will, and a more universal charity than the past ever knew or dreamt of, which even the present yet scarcely foresees the outcome of, and which perchance, the future will fully realise, into the brotherhood of all mankind, and the loving practice of "peace and goodwill on Earth unto all men!”

"Yes, my brethren, oh! be hopeful, for the storm precedes the shine,

Thro' the clouds of ignorance roll we-on today-dawns more divine." 62

Whitman practises what he preaches by "singing of steam" in his "To a Locomotive in Winter," thus- 
[Twenty lines from "To a Locomotive in Winter," Two Rivulets, 25-26.]

A very characteristic poem of his, though much less "extravagant," is

["Eidólons," Two Rivulets, 17-20.]

In his habit of life he is represented to be "a very Diogenes," to whom a shady hedge in summer, and a sheltering hut in winter is "room" and "roof-tree," of which, in the old songster's words-

"Minds innocent and gentle make

Of such an hermitage!" 63

A man to whom "bread and herbs, and contentment therewith," is literally, as well as figuratively, a feast; but to whom, unfortunately, it seems even such simple necessaries have become all but luxuries, and not always even within his reach, humble though they be! - and therefore to Walt Whitman, the man who "lives the life that is in him" freely and fearlessly, even though its means be poverty, and its end be want, the heart of each real man goes forth with instinctive fellowship, and more reality of sympathy than if he were crowned with laureate bays, and had sold his "tenth edition," giltedged, and illustrated by Doré, by its hundreds of thousands! ${ }^{64}$

The correspondent from whom we quote, says of him:-

[Three paragraphs from "New Work by Walt Whitman," London Daily News (March 11, 1876), 6.]

We have not his "Leaves of Grass" at hand from which to give extracts of his earlier style, but trust our readers will be able to form a tolerably fair judgment, both of himself and of his works, from the above fragments, in which there is most undoubtedly-despite roughness of style and involved phrases and misty meanings - both power and real originality of thought, in fact, the real "Maker." Whether he will "live," time, which tries all things, must be the one proof of - but in any case he is neither a mere ready-rhymester nor a pleasing plagiarist, and in this age of shame and shoddy, it is refreshing to come across a bit of real nature, even though rough and rugged, and to feel and believe that instead of the ordinary modern "polished Pontius Pilate" of literature asking "what is truth?" with more scorn even than pity in the sad enquiry, you are reading the beliefs of a man who believes he sees truth, and manfully believes in uttering it as he sees and hears it, and also believes he is an appointed utterer!

In conclusion, and as showing the sentiment of some of his admirers in England, we subjoin his brother poet, Robert Buchanan's, letter, with the sentiment and suggestion of which we heartily sympathise, and trust that it will not appeal in vain to all the liberalhanded and large-hearted of both Walt-Whitman's countrymen and our own. [. . .]

\section{[W. Brockie?]. “Two Rivulets.” Sunderland Weekly Times [England] (November 17, 1876).}

This is a book which thousands will read with intense interest, and tens of thousands throw down in sheer disgust. The former will be such persons as can look beneath the surface, and discern true worth under the most uncouth garb; the latter those who are content to follow the fashion, and take their opinions of poets and philosophers, as they do of bodily costume, from others. Walt Whitman's poetry is like no other that ever was written - boldly conceived, bluntly expressed, purely American yet cosmopolitan - not in the least conventional - uncramped by regular metre-disdaining to be scanned by conceited pedagogues - semi-savage yet most humane-Cyclopean in form and effect. In the book before us, his peculiar powers are exhibited in all their innate force, and the prose part is quite as original and interesting as the poetical part. There is a strange fascination about the whole, to such as are susceptible of feelings unstamped with the seal and signature of admitted authority. All others will, as we have said, declare the writer a bore, but for that there is no help. The deficiency is in them, not in him. 
"Walt Whitman's Poems: Extracts from Two Rivulets." [NewYork] Daily Tribune (February 19, 1876), 4.

\title{
MEMORANDA DURING THE WAR (1876)
}

\author{
"Review [Memoranda During the War]." Sunderland Weekly Times [Eng- \\ land] (July 7,1876 ), page number unknown.
}

\section{LEAVES OF GRASS (1881-1882)}

\section{"Our Boston Literary Letter." The Springfield Daily Republican (No- vember 10,1881$)$.}

[...] It was a great age, men will say hereafter, and a grand country that could produce in one generation three figures for posterity to gaze on like John Brown, Abraham Lincoln and Walt Whitman,- men unlike each other and unlike all others, such as no other land produced or could produce; embodied heroism, embodied sense and sensibility, embodied imagination. So I view the three men, in the mass of their character, - not considering the loose and trivial details which to many eyes have seemed to be the whole character. It if were possible to see the genius of a great people throwing itself now into this form, now into that, - as the prairie wheat-field takes the quick shape of the passing wind-it would be just to say that we had seen this mystery in the "plain heroic magnitude of mind" with which [John] Brown met death, ${ }^{65}$-in the broad and patient wisdom of Lincoln, - and in the immense landscape of Whitman's teeming and unharvested imagination. His "Leaves of Grass," as he has now published them at Osgood's in Boston, complete the vast picture of his mind and bring out not merely the confusion of details, which we could only see at first, by the light of poetic flashes - but the broad unity of the piece. It is as if the ancient seamen had found their ocean-god slumbering along his shores, and upon near view could only see a hand here, an eyebrow there, a floating mass of beard elsewhere,- - but when they stood back from the strand, or best if they climbed a hill of prospect, the symmetry and articulation of the mighty frame plainly appeared, and they knew by sight their unconscious divinity, Neptune. There is in Whitman's verse, more than in any other modern poet's, what Keats called "that large utterance of the early gods," - an indistinct grandeur of expression not yet molded to the melody of Shakespeare, Lucretius and Eschylus, but like what Keats again calls "the overwhelming voice of huge Enceladus":-

"Whose ponderous syllables, like sullen waves

In the half-glutted hollows of reef-rock

Came booming thus," - 66

[Seven lines from “So Long!” LG (1881-1882), 380-381.] 
It is when he speaks of Lincoln and the civil war that Whitman is least indistinct, and no other of our poets - no nor all of them together-has so well caught and rendered the spirit of that struggle as he has done it. As has been remarked by others no doubt, and more than once, Whitman gives the whole episode of slavery in its relation to the war, in the strange fragment called

["Ethiopia Saluting the Colors," LG (1881-1882), 249.]

This new volume of Whitman's contains philosophy, antiquities and history all in one, and is the book of the year in Boston which will bear the most reading and study. The only one to compare with it is another of Osgood's publications, Mr Cooke's "Ralph Waldo Emerson,"-and the two are curiously related to each other. But for Emerson, Whitman might never have written, or written in another form, and what can be further from the Emersonian mode of writing than these unformed and almost lawless numbers, this broad range over the most prosaic elements of life, as well as those regions of ideal beauty in which the genius of Emerson delights?

\section{"Walt Whitman, a Kosmos." The Springfield Sunday Republican (No- vember 13, 1881), 4 .}

To make a mark on the sands of life in this busiest, windiest and most tidal period of the world's history, and to keep that mark fresh and deepening for seven-and-twenty years, is no little achievement for an American author. This Whitman has done, and something more than this. When in 1855 he printed with his own hands his odd and sprawling lines of his "Leaves of Grass" (a few copies, long since out of print, though hardly any one bought them), he announced himself to the world as a poet, and he has never since taken down his sign. He still carries on business at the own stand; still "sounds his barbaric yawp over the roofs of the world." But now instead of six readers he has six thousand, or perhaps six hundred thousand and the back countries have not all been heard from yet. That they understand him we would not guarantee- he does not understand himself always; still less did he understand himself when he began to write. He put to sea on a raft and his only compass was a looking-glass, but he has made as good a voyage on the whole as if he had sailed in the Great Eastern with all the compasses and chronometers and astronomers on board.

Were it the will of heaven an osier bough

Were vessel strong enough the seas to plow. ${ }^{67}$

So said Pindar, only more shortly, - and Whitman has verified the oracle. Courage and trust are the best outfit for a poet it seems; they are worth all the colleges and libraries in the world. The world itself is the poet's library, and Whitman has had a card to that collection; he has even attempted a catalogue; but like all library catalogues it grows beyond his power to list and index.

There is a lawless saying, fit only for the wise, but full of meaning for poets and great captains,-

Oft have I heard, and deem the witness true,

Whom man delights in, God delights in too. ${ }^{68}$

But the career of pleasure and admiration which is only possible to power soon finds its limits in human experience, and must be corrected by the sharp lessons of sorrow and mortification,- - must be continued, if at all, by the completest self-renunciation and trust in the unseen powers. This discipline Whitman has had, it would seem, and has profited by it. His later poems are not quite in the key of his earlier; they have a more serious and religious tone; and their light is thrown back on the dangerous utterances of his youth. He has not rejected these utterances, - has indeed preserved most of them in this new volume,- - but has softened them, changed their connection and brought them into a better accord with a life of service to mankind, such as the poet's must be if he 
would live beyond his own age. Consequently this book will be received, we fancy, as none of Whitman's former books have been. It will no longer be a work prohibited, but, in spite of many passages which must always keep it from a familiar place on the table, and from the perfect liberty of unformed judgments, - it will find its way into all good libraries and into many homes. For the civil war made Whitman a domestic poet, which he had hardly been before. The clear recognition and pathetic portrayal of the home affection in the Americans, not less than their patriotism and devotion to democracy, gives "Drum Taps" an affectionate place in the hearts of his readers. The philosophy of "Leaves of Grass" was oriental, - grand, but peculiar, and to the multitude either irreligious or suspicious, - but this was changed in the war-poems into a spirit which the multitude could understand, because they shared it, - which, indeed, was born of the multitude and possessed Whitman as one of the many, not as among the few. Another change noticeable in him at that time and since affected his meter and the melody of his verse. The measure of the old chapters in "Leaves of Grass" can hardly be called a meter at all: what rhythm it had was rather like the rhythm of Hebrew poetry, in the antithesis or repetition of ideas, not in the harmonious arrangement of words. But it would seem as if the music of the regiments:-

"Sonorous metal blowing martial sound,"

had suggested to Whitman a new movement for his lines ${ }^{69}$ They soon became measured and choral in their character,- - not a set measure, like the tweedle-de-dum, tweedle-de-dee of the mediocre poets, but a dithyrambic orchestral movement, responding to chords struck at irregular intervals, and leaving the mind free to catch up the next strain, wherever it might come in. This in part is the secret of the Greek chorus-poetry, to which (though the Greek measures are more balanced and mutually responsive) the war pieces of Whitman, and much of his later poetry, bears a strong resemblance. The book deserves study even as a metrical anomaly, were it not entitled to consideration upon much higher regards.

Lofty as any sound estimate of Whitman's book must be, it has faults enough to have long ago destroyed the reputation of any writer who had not something better than singularity to commend him. Concerning these, as well as for a larger consideration of his work and place, we shall take another time to speak. Here we say only that the book is a noble one, and must be so adjudged before any proper discount upon its merits can be made.

\title{
“Leaves of Grass.” Boston Globe (November 13, 1881), 8.
}

\author{
"LEAVES OF GRASS." \\ Kosmos, or Walt Whitman's Song of the Universe. \\ A Perfect Poem-Picture of American Democracy. \\ The Hermit Thoreau's Opinion of Our Good Gray Poet.
}

Should any one ask the question, "Will Walt Whitman, the poet, and 'Leaves of Grass' (the work on which his fame will rest, whatever he may write in the future), now that after upward of twenty-five years of patient waiting both have got within the sacred circle controlled by a syndicate of literary men and publishers, become rapidly popular?" The answer must be, "No." The book is too radical, too free, too independent and far too true to make its conquest of a popular verdict an easy matter. To the question, "Will the book and the man ever be popular?" the answer, in the opinion of the present writer, must be a qualified "Yes." Walt Whitman is, par excellence, the poet and priest of democracy-the American type of democracy; the democracy based upon individuality, though not, perhaps, the ultimate democracy; the democracy based upon I, the individual; not the democracy based upon we, the 
sum of all individuals. In "Leaves of Grass" Walt Whitman has personified—or rather, idealized - the genius of American democracy. The work cannot be separated into any number of complete and independent poems: it is one complete and all-embracing poem, the subject of which is the Kosmos. It is the Kosmos as viewed from the standpoint of the American idea of democracy - the sovereignty of each and every individual. Walt Whitman is an individualist of the most pronounced type. So, while admitting that his grand psalms of the Universe will attain a gradual and limited popularity, attaining such popularity only as fast as they become popularly understood, their influence may diminish should ever the American idea of democracy - individual sovereignty-lose its hold on popular opinion.

Walt Whitman has written the drama-it may be almost called the history-of the first century of American civilization. It may be doubted whether it will fit the second century as well; indeed, how could that be expected, for is it possible to write

The Drama of the Future?

All that we can know of the future we have learned from the past and from what we can understand of the tendencies of this present time; but what poet or seer, let him be ever so wise, can forecast the future development-even for one brief century-of the wonderful, creative, multitudinous human mind? But let us take a survey of the book. Let us see how far it fits the foregoing remarks. First, as to the title-why "Leaves of Grass?" The author himself evidently loves the title, as is evinced by the ornamentation not only of the latest but of previous editions. His very signature on the cover reminds one of grass - and it has a meaning. Let us read the opening in his own words:

[Twelve lines from "Song of Myself," LG (1881-1882), 33-34.]

"Leaves of Grass," then, are not only symbolical of all the great alchemy of nature, of all creation, all production, all evolution, but symbolical of immortality as well - the permanence and indestructability of all things. And so the title is good.

What of the man? What of Walt Whitman himself? This brings us to one of the most interesting features of the book; indeed, the key to its entire plan - its marked personality. It was not by mere whim or caprice - much less by accident or any publisher's devicethat the unique portrait of the author (the only illustration of the volume) is not in the usual place, fronting the title-page, but incorporated in the verse, and accompanied by his account of his own relation to his work and to the reader. This is introduced as a

Song of Myself,

and is carried through fifty-two stanzas, occupying fifty pages. The portrait, copied from a daguerreotype taken in 1856, when he was a working carpenter, as well as an unhatched poet - represents him in the loose shirt, open at the neck and lapping over the waist of the unbraced pants of an ordinary mechanic; his flannel undershirt revealed; a broad-brimmed, soft felt hat carelessly thrown back sideways on his head, which is inclined in the same way. The expression on his face shows energy, self-reliance and is full of thought; his attitude is firm, careless and unstudied - the left hand in his pocket and the right resting with bent elbows on his hip, which is thrown up to support it. There he stands - Walt Whitman - a man and a workingman; every line, every shadow, "every atom of blood" and fibre of him. But let him speak for himself:

[Forty-three lines from "Song of Myself," LG (1881-1882), 29-33.]

"A child said, What is the grass?" etc., then comes in, and for several pages the reader's attention is chained to

A Beautiful Panorama of Human Life

in all its various aspects, civilized and uncivilized; to all possible life experiences of men, women and children; life animate and inanimate (if the term is admissible), all of which, and all actions and feelings and promptings and meanings, are embodied in himself, and felt and expressed by himself-Walt Whitman. We can only cull a specimen or two here and there as we turn over the charming pages: 
[Thirty-one lines from "Song of Myself," $L G$ (1881-1882), 39, 42, 43.]

Now comes a passage remarkable for its nobility:

[Thirty-one lines from "Song of Myself," LG (1881-1882), 43-47.]

Now for the key-note of

Our Author's Cosmopolitan Personality:

[Ten lines from "Song of Myself," LG (1881-1882), 48.]

Here is a suggestive word to impatient revolutionists:

[Three lines from "Song of Myself," LG (1881-1882), 53.]

Listen to this, ye who see no poetry in "Leaves of Grass:"

[Twelve lines from "Song of Myself" LG (1881-1882), 53-54.]

Turning over page after page we reach the following:

[Eighteen lines from "Song of Myself," LG (1881-1882), 71-72.]

Here we have in epitome the true story of

The Creation of Man.

And what comprehensive grasp of infinity, what far-reaching perception, is revealed in these lines:

[Fourteen lines from "Song of Myself," LG (1881-1882), 72-73.]

Here are a few lines that show the fulness of his fellowship with all others:

[Thirty-three lines from "Song of Myself," LG (1881-1882), 73-75, 77-78.]

Will what has been written and quoted serve to give some idea of the spirit and meaning of this wonderful poem of humanity and the universe? It has been written with the hope that it may, but with no expectation of doing anything like justice to the vast range of observation, profundity and minuteness of analysis, philosophic and religious interpretation, intimate knowledge and deep and earnest sympathy, not only with all humanity but with all nature, that

Place this Book in the Front Rank

of the highest branches of American literature. One might as well try to epitomize Shakespeare in a newspaper article as to try to do so with "Leaves of Grass." That all who read this imperfect review will be induced thereby to read and study the volume for themselves, and become greater, nobler and happier by the experience, is the earnest hope of the writer.

The following appreciative opinion of, that other faithful student of nature-Thoreauwritten in 1856, and therefore at a time when even a man of his independence could hardly be expected to be very outspoken in the face of social prudery, will be read with interest, and will be a fitting appendix to what has been already said:

[Excerpts from two Thoreau letters to Harrison Blake]

Thoreau has evidently written just what he felt when the surprise and what may be called the shock of an unprecedented revelation was fresh upon him. His candor and his good judgment, under the circumstances, is worthy of all commendation, but he might write differently today were he alive.

\section{"Leaves of Grass." Saint Paul and Minneapolis Pioneer Press (December $12,1881), 4$.}

Since the issue, years ago, of a strange, thin volume, bearing this title, the thinkers of the world have been busy in attempting to read the riddle of these poems and their author. The struggle has raged fiercely about every point, from the question whether the term "poem" can properly be applied to these odd recitatives at all, to the question of their meaning and their inspiration. The complete works of Walt Whitman are now put into the hands of the old generation and the new, to do what work they may; but by this time criticism should have crystallized into something definite, and the world ought not 
longer to go on wondering, each man scanning the face of his neighbor before venturing upon an opinion of his own. And first, let the old quarrel about the form of these poems be finally dismissed. The question of the fittest form for the expression of poetic ideas is as old as human thought, and different ages and nations have answered it differently. The modern rules of rhyme and accent would have seemed senseless to the Latin or Greek prosodists. All these matters are mere conventionalities; and if a man's genius direct him to write in measures hitherto unknown, why let him be judged independently of what are little more than the literary fashions of the day. Whitman's chants strike rudely on the ear at first; but there is in their very construction an element of the magnificent old Hebrew rhythm which marks the book of Job the grandest of epics. They are not mere accidental jumbles. The reader with an ear for music will detect a theme running through them all, which will satisfy him as well, if he be a thoughtful man, as if he could scan them glibly by anapests or trochees. That Whitman is a great poet, it does not require a long reading to discover. From this volume could be collected more absolutely fresh instances of that creative genius which is the progenitor of poetry than from any writer of modern times. Metaphors of singular fidelity and beauty, such as "the fan-shaped explosions," crowd upon and round out the lines. Who that has ever heard it can forget this one?- "The carpenter dresses his plank, the tongue of his foreplane whistles its wild ascending lisp." Many of his short poems are as clean-cut as crystals, and as melodious as more strictly measured cadences. The "Drum Taps" are famous everywhere; and, though later efforts have been less happy, the one exquisite song, "O, Captain! My Captain!" written on the death of Lincoln, would make him one of our honored poets forever. When mere formal objections are laid by, the most obvious surface criticism upon Whitman is his apparent egotism. It is everywhere "I," "me imperturbe," "I project the history of the future," "You do not understand me, you cannot understand me, but I can wait hundreds of years for my audience, and they will understand and applaud me." If these were merely the mouthings of individual pride, they would inspire deserved disgust. But they are the words of a man who has a message and proves it. Everywhere, to him who reads aright, the personality of the prophet is sunk out of sight, and the prophecy is exalted. This man feels that he has a message to the multitudinous generations. The grandeur of humanity, the oneness of creation, the beauty and the glory in that one word, "life," the meanness of social and artificial distinctions, the grand eternal sweep of cosmic laws, the dignity of everything that is, simply because it is, and the onward march of all things mean and great toward a wondrous destiny, - these are the high thoughts which reduce language almost to incoherence, and fill the seer with unutterable exaltation. [. . .]

$\mathrm{He}$ is, indeed a poet who sees far and keenly; and no doubt the reader of the future will believe it still more than we. One other current objection must be briefly met. Public and publishers have cried out upon his indecency. It is true that there are in this book things which no man observant of conventions would have dared to print. But it must be said of them, as he says of his poems, that the words are nothing, the tendency everything. His lines are bold and startling, but you can look them through and through and find no prurient suggestiveness. His aim is to glorify human nature as God made it, with powers complete but undefiled. Delicate modesty feeds upon Swinburne, but flees with down-drawn eyelids from Whitman; yet the pages of the latter are to those of the former what a gallery of Greek sculpture, filled with noble, life-like, marble figures, is to the cancan upon the stage of the Paris Varieties. The real, consistent criticisms upon Leaves of Grass have been uttered, if at all, but by few and with hesitation. Whitman seems to have in undue amount the author's tenderness, born perhaps, in this case, of his sense of the greatness of his mission, for every word he has written; and this has prevented the exclusion of worthless matter. The few lines, for instance, entitled The Ship Starting, contain neither thought nor figure of beauty that entitle them to life. And in his longer poems the tiresome enumerations of States, countries and avocations, which sometimes 
spread over pages, are but the wanderings of heated imagination and vivid fancy, detracting from both the inner thought and the outer artistic effect. To cut down the volume probably one-fourth, if judiciously done, would exclude nothing of present or possible future value. The constant use of such words as "ostent," "sidle," "sluing," and the like, is bad English and worse taste. Again, he is open to the charge of making his thought unnecessarily obscure. Doubtless he himself cannot grasp in their fullness all the mighty ideas which float illusively before him. He is like a child attempting to describe Niagara, or like him who could not utter a word of the things he saw and heard, when caught up to heaven in a vision. But he is, nevertheless, unnecessarily mystic and incoherent. Those who have penetrated to the heart of one of his Delphic sayings can see that its intent was purposely shrouded in vague, verbal involutions. Not only might he have sooner won his place, but he might have done better the work in which he glories, had he courted the strong simplicity which none is better able to master. Leaves of Grass has won its own way, and is sure of its place. Few American authors have the reputation abroad which Whitman has attained. At home he is destined to a closer and more admiring study as the years go by. From such a discipline it is not impossible that a greater future poet may draw virility and inspiration, while avoiding errors which impair the strength and the popular influence of a work unique, original, careless of standards and traditions, yet replete with beauty and power.

\section{"The First American Poet: Walt Whitman-Justice at last-A Great Poet Completes a Great Work." The Worthington Advance (December 22, 1881), 2.}

The announcement was made some time ago that Walt Whitman was in Boston personally superintending the publication of his poems under the title of "Leaves of Grass," the name used in issuing his first thin volume, which threw all the conventional critics into spasms of laughter and disgust. But twenty years have wrought a mighty change. Whitman has steadily grown in favor in Europe and hence his own countrymen have taken him up and have gradually come to see that a great and original poet has been among them.

James R. Osgood \& Co., of Boston, have just issued a volume of 382 pages containing Whitman's complete works. It is now discovered that from the beginning the poet had a purpose to which he has steadily adhered; that for thirty years he has been laboring on a great work with one aim, and that what seemed fragmentary were the parts of a great whole, the segments of a mighty circle, which the purblind public could not see or comprehend at one view.

The Pioneer Press a few days ago noticed these poems in a column article, doing justice to the poems and the poet. From England and America we expect to hear a reversal of the judgment of the flippant and shallow critics of twenty years ago and henceforth Walt Whitman will take a permanent place in history as the father and founder of a distinctively American literature.

We rejoice at this, for we were among those who first hailed Whitman as a poetic star of great magnitude rising over the horizon. In the year 1860, we published a literary paper called "The Fireside," in which we devoted a page to Whitman, quoting from the Westminster Review an adverse criticism and taking issue with the shallow reviewer. ${ }^{70}$ The British review thus spoke of the poems:

In form these poems, if poems they can be called, are composed of irregular rhythmical lines, after the manner of Tupper, and in fact they may be described by the following equation: as Tupper is to English Humdrum, so is Walt Whitman to American Rowdy. 
That a drunken Helot should display himself without shame in the market place, speaks sad reproach to the public that does not scourge him back to his cellar.

To this the Cincinnati Commercial added:

This is deserved, and yet there are dirty dogs and dunces who praise Whitman's indecency, and call him a "masculine poet" because he is an obscure ass.

In reply to this we said twenty-one years ago, page 106 of the "Fireside":

Nevertheless, Walt Whitman is a poet. We expected better things of the Westminster Review. The above is of that shallow kind of criticism which flounders about on the surface and cannot reach down and feel the drift and great undercurrent of a work. Whitman is as much a word-painter as Bryant and a great deal more original, simple and masculine. No writer has ever given such a complete and natural picture of the external life of America. The man who is too much shocked by its "indecency" to find any beauty in "Leaves of Grass," must have a very tasty taste. Whitman is a poet, but a poet rather in the rough.

We envy Mr. Conway, of the "Dial," his remark, viz: "Walt Whitman has set the pulses of America to music." 71 There is more justness and appreciation, and comprehensive criticism in that short sentence than in all the conservative critics have said about Whitman.

We well remember how the "thothiety" editors and the smart youths whose conception of poetry extended only to "Marco Bozzaris" and "Hohenlinden" jeered at these poems!72 How they referred to the poet himself as a product of the "Brooklyn Flats" and as the "red-shirted omnibus driver" of the metropolis. Yet Walt Whitman has made a profound impression on his time. And while he will probably not be generally read any more than Chaucer is. Yet the time will come when Whitman will be looked upon as the father of an American literature, that is of a literature distinctively and in all respects American, without any kingly, or monarchical or European influences in it.- He has laid the foundations, started the idea, of a genuine Democratic, New World, thoroughly American literature, and after him will come some great poet who will be the Shakspeare to this Chaucer. Moreover he is a genuine American man, the most original and truest Democrat of his time. The man is greater than his poems. His works, as the expression of a thoroughly original, democratic, human being, are invaluable, and on this foundation some mighty genius hereafter will build a literature and the gates of hell and time shall not prevail against it. Longfellow, Bryant, Whittier, Lowell and the rest will be remembered in the Cyclopedias as poets who did creditable work in English literature, but Whitman and his class will loom over the future as the founders and makers of an American literature.

\section{"New Publications: Leaves of Grass." Philadelphia Press (December 23, 1881), page number unknown.}

The prophet, of whom it was once said that he was not without honor except in his own country, has now, if not a circle of disciples, certainly a large and increasing audience of admirers. Several magazines and newspapers, which either received the words of "the Good Gray Poet" with abuse, or refused to allow their pages to be sullied with a notice of his "monstrosities," now welcome his life-work with little short of unstinted praise. Nor is this due to the fact that a great publishing house gives its imprint to the title page. The reason lies deeper. While upon some natures his name still has the effect of the traditional red rag upon the angry bull, the majority of cultivated minds begin 
to see that Walt Whitman is the most American of poets and one of the brightest lights of American literature. It is worth while, then, for even very briefly to examine some of the adverse criticisms that have been passed upon Mr. Whitman, and to see how much weight they really have.

First, it is said that the form into which he throws his verse is chaotic, that his poems run to "a chaos of monotonies," and hence his book makes war upon all theories of true poetry. The same criticism would shut out of the category the English Psalms of David, and the best and most satisfactory translations of Homer and the Greek dramatists, Virgil and Dante, Goethe and Victor Hugo. These authors are still poets in the most literal translation, and the man who can read Whitman and find no rhythm lacks a musical ear. He has the most astounding variety of meters suited to every slightest change of sentiment, here lilting like a smooth flowing river, here carrying the reader along with all the rush of a Niagara, and again blocking itself with wonderful expressiveness. A study of Whitman's meters would be no more interesting and instructive than that which is spent on the complicated, and to us moderns the meaningless, systems of the Greek strophe and antistrophe. Take these four lines from "A Broadway Pageant." They are worthy of Horace:

[Four lines from "A Broadway Pageant," LG (1881-1882), 193.]

And hundreds of other instances could be given. Again, it is said that the catalogues with which Walt Whitman loads his poems are unpoetical. Without attempting to argue the point it may be said that were all records of America destroyed and Walt Whitman's poems preserved, the daily life of the nineteenth century might be pictured with almost photographic accuracy from the same much-abused catalogues; and, moreover, if anyone reads them understandingly he will not fail to be impressed with their picturesqueness and contrast their felicity of descriptiveness, and, taken in connection with the plan of the whole work, their appropriateness. And this brings us to a third adverse criticism: That the work has no unity of plan. To a narrow conception this is true. It needs a wide perspective, and, if these poems had been left to us by an ancient bard, they would have been prized as the most precious memorial of the past. The old story of the sculptor is not inapplicable here. Seen from a level at a short distance the statue appeared monstrous and coarse; but when erected upon its proper height, the rude lines melted into softness and the coarse features were seen to be simply majestic. His boldness of touch is admirable; his pages are veritable panoramas of life; his observation is all-embracing; nothing fails in the picture, and he is equally at home on the wide plains of the West, the wind-swept "gray beach" of the Paumanok shore, or amid the eddying swarms of the city. His adjectives are often worthy of Homer, and his view of the universe wider than Goethe's.

A common charge against Mr. Whitman, is that of his overweening vanity. It must be admitted that if his every utterance be taken as the expression of his personal individual feeling, vanity could not go further; it would be the acme of conceit. But this again is a narrow view. Mr. Whitman symbolizes himself in the grandeur, the spread, the vast liberty of the man. It is the ideal of self-conscious Pantheism. "The Song of Myself," is not Walt Whitman in any small way. Myself is man idealized, and every pleasure, every passion, every pain which goes to make up the life of the world, is centred upon him as a sentient being capable of all things. Looked upon ideally, therefore, there is no conceit in it; aside from its form, it is the grandest conception of poetry which this century has given, and, if read without prejudice, cannot fail to stir the heart. The egotism is the egotism of the poet, and may be seen in these lines from the greatest of the Welsh bards, which bear a curious similarity in form to Mr. Whitman's poems, though possessing individuality of their own:

[Twenty lines from "Taliesin," The Mabinogion, trans. Lady Charlotte Guest, 1849.] 
And it is said that when Taliesin had finished his song, the kings who heard it were filled with marvel. ${ }^{73}$

A still further objection, and the most serious one which has been urged against Mr. Whitman, is on the score of morality. It is claimed that he sins against purity, that he is the poet of the phallus and unbridled lust and indecency. Such a charge is extravagant. The lines which could be condemned on such a plea bear but a small proportion to the rest, and it may be said in defense that were its immodesty to shut it out from libraries, the Bible, Cervantes, Shakespeare, Goethe, and most of the master-pieces of literature would have to suffer in the same way. Again, it was not written for babes and sucklings, and the person who can get food for vile imaginings from it would be fed equally from a thousand other sources; honi soit qui mal y pense. ${ }^{74}$ It can hurt no true man or woman. As regards the question of taste, the chemical view of matter which can reduce a vile and a pleasant odor, rot and sweet, smut and diamond-dust to the same elements is not the most conducive to poetry, and here it seems as though Mr. Whitman failed. Granting his premises that "If any thing is sacred, the human body is sacred," still personal preferences, the love of the beautiful, the true, the high, the noble, the best that is meant in the word "taste," is also a part of human nature and therefore superior to the excremental, the disagreeably physical view of man. Mr. Whitman might have consistently taken this ground and raised his poems immeasurably in the eyes of the world which he claims to love, by expunging a few expressions which cannot fail to offend the taste of the reader. Some think it a greater sin to break the laws of good taste than those of morality. Moreover, it is a question whether the attempt to carry out his colossal plan of depicting humanity in its every phase is worth while, since it places his most stimulating, most inspired and grandest utterances out of the kin of the very boys and girls who are growing up into the future men and women, which his verse exalts. We believe in an expurgated Bible, an expurgated Shakespeare and an expurgated Whitman, at least for the use of the young. The question of Mr. Whitman's sins against the English language is of less consequence. Good taste would alter a few; others which make the critics howl are legitimate if North and South, East and West and the [sic] all the French, German, Spanish elements of our country be taken [into] consideration.

We have assumed all along that Mr. Whitman is a poet. Some critics deny this, but we venture to say that had Leaves of Grass come down to us from antiquity, it would be the universal claim that they had the sweep and magnificence of the epic and the variety and expression of the lyric. There are poems in "Drum Taps" which stir the heart like a bugle:

[Seven lines from “Beat! Beat! Drums!” LG (1881-1882), 222.]

King David would not have been ashamed [of] this psalm:

[Thirteen lines from "Proud Music of the Storm," LG (1881-1882), 310.]

Without even [gap] any definite way [gap] hesitate to place [gap] ${ }^{75}$

\section{“LEAVES OF GRASS. Walt Whitman's Poems of Nature.” Detroit Post and Tribune (date unknown; possibly 1882-1883), page number un- known.}

[Six lines from "Song of Myself," LG (1881-1882), 33.]

There never was a happier title than the one which is the caption of this paper, nor one that has attracted more attention in the American world of literature. It is the title of a book that has been challenged by the conservers of public morals as unfit to be read, and legislation has been appealed to unsuccessfully to prohibit its publication. As usual in such cases, the reaction increased the demand for the book to such an extent that 
several new editions have been called for and it is found on the shelves of book stores side by side with Longfellow and Tennyson, in the home and in public libraries, where the critical reader or student of verse can have access to it, and the human nature that can suffer from any undue license of the poetic imagination which Walt Whitman has transcribed on these pages must be very weak indeed and easily harmed.

There is not a line of prefatory writing in Leaves of Grass, not a foot note to clear up the passages in nature which God has left obscure; the writer does not explain that the poems were a result of a few idle hours or the reveries of an invalid convalescing from an attack of mania a potu or typhoid fever; he pours out his thoughts about everything in a flood of incoherent and incohesive language, and borne on its resistless flow we find all that floods bear with them, debris, flotsam jewels - tarns of still deep beauty jewelsprecious, perishing lovely things that we haste to snatch from the rubbish and make our own. His interest in humanity and his claim that all the world is kin, he expresses with natural humility:

[Five lines from "Song of Myself," LG (1881-1882), 43.]

Can any pen-picture of nature be finer than his apostrophe to the earth on page $76::^{76}$

[Ten lines from "Song of Myself," LG (1881-1882), 46.]

There seems to be no earthly property however small, insignificant and remote, that this grand poet of nature does not invest with the beauty and glory of poesy as he does when he calls the common field grass "the beautiful uncut hair of graves," a line that in itself should immortalize him; he walks among the herds of cattle and gives us this lesson:

[Eight lines from "Song of Myself," LG (1881-1882), 54.]

The self-elected critic who said that Shakespeare was not a poet-his verses didn't rhyme-would make a similar objection to Walt Whitman. To the dull, untuned ear of the prosaic soul they would convey neither rhythm nor rhyme, but Poetry herself might sit entranced at his feet as the mellow numbers flow in tranquil rhythmic measure from his lips. Here are snatches selected at random, any one of which would be sufficient to redeem a volume from wastage:

[Eleven lines from "Faces"; "Mother and Babe"; "A Child's Amaze"; and "Beautiful Women"; $L G$ (1881-1882), 355-356, 217.]

The poet's allusions to death are among the finest passages in his works, and his songs of parting are something more than tricks of pathos; they are the outcome of sorrow's cleansing fires in his own heart. The Camps of Green is a poem engendered by war scenes.

[Four lines from “Camps of Green”; “Joy, Shipmate, Joy!” LG (1881-1882), 378, 379.]

The exquisitely mournful tribute to the memory of President Lincoln is familiar [to] the reader but it will bear producing here.

[“O Captain! My Captain!” LG (1881-1882), 262-263.]

To analyze a flower is to kill it; the same might be said of the majority of even fine poems, but there are some that dissected fall into pictures and the above is one of these; the two lines

"Here, captain, dear father,

This arm beneath your head"

have the heroism of a soldier and the tenderness of a woman in them, while they instantly convey to the mind a picture, alas! too common to excite alarm or wonder, but inexpressively touching. It has been Walt Whitman's destiny to commemorate in verse the deaths of two captains of the ship of state, but to him the first was a personal loss. Of the last, midnight, September 19, he writes of

The sobbing of the bells-

- Those heart-beats of a nation in the night[.] 
Emerson appears to have accepted the poet, if we may believe the assertion of an unknown writer that he approved of Leaves of Grass. It would need one of Emersonian breadth to appreciate the vigor, the intensity, the strong balancing of all mental and physical forces in this redundancy of verse. The book is full of such salt-sea breezes of expression as these:

[Six lines from "A Song of Joys," LG (1881-1882), 146-147.]

That verse or sentence alone could be profitably engraved upon the pages of every school reader in the land, yet doubtless there are hypercritical readers who would cavil at the second line and find in it a furtive attack on all the known systems of theology.

And is there nothing in the book to condemn? Yes, there are whole pages of "magnificent uncleanness" which have no excuse for being. ${ }^{77}$ They are gross with the grossness of the $18^{\text {th }}$ century, when people do not call a spade a spade, and are shocked by ungloved hands. In reference to the position which a part of the public has taken towards the book we are reminded of the answer Henry Ward Beecher gave to a gentleman who at an exhibition of statuary asked, "Are those statues indecent, Mr. Beecher?"

"No, sir," was the severe answer, "but your question is."

The poet is an old man now, the fires of youth have burned themselves to ashes, yet when he was called upon to revise the present edition of his work he would not alter or omit a line of his earlier writings. The calm pulse of age approved the turbulent blood of his youth when he wrote of himself:

[Five lines from "Song of Myself," LG (1881-1882), 48, 49.]

And this man in his old age is beloved of women and children, and the childlike tenderness and simplicity of his nature are revealed in the following incident:

"In the middle of the room in its white coffin, lay the dead child, the nephew of the poet. Near it in a great chair, sat Walt Whitman surrounded by little ones, and holding a beautiful little girl on his lap. She looked wonderingly at the spectacle of death and then inquiringly into the old man's face. "You don't know what it is, do you, my dear," said he, and added, "we don't either."

\section{"New Poetry of the Rossettis and Others." The Atlantic Monthly 49 (January 1882), 119-126.}

[...] The appearance of Walt Whitman's Leaves of Grass in a new edition has revived a discussion always imminent when the name of this writer is brought forward, and always more or less acrimonious. Some persons even imagine it obligatory upon them to deny him all merit of poetic endowment, so violent is their revolt against the offensiveness which Mr. Whitman has chosen to make a central and integral point of his literary method. Such critics stultify themselves by the coarseness of view (and sometimes of expression) with which they meet the grossness they condemn. If they can see nothing in this book except indecency and bombastic truisms, the inference must be that their sensibilities are not delicate enough to recognize the fresh, strong, healthy presentation of common things in a way that revivifies them, the generous aspiration, the fine sympathy with man and nature, the buoyant belief in immortality, which are no less characteristic of the author than his mistaken boldness in displaying the carnal side of existence, and his particularity in describing disease or loathsome decay. It would be a waste of time to discuss the question whether or not Mr. Whitman is a poet: abundant authority, both creative and critical, has recorded itself on the affirmative side. Nor is it worth while to debate upon the form he has adopted, which - as Mr. Stedman in his temperate and admirable essay has shown-is not the startling novelty which many, including the poet himself, have assumed it to be. ${ }^{78}$ 
The only profitable point of view from which Leaves of Grass can be regarded is one that, while giving distinctness to the serious error of unclean exposure and to the frequent feebleness of form and style which reduce large portions of the work to tedious and helpless prose, leaves our vision clear for the occasional glimpses of beauty that the book discloses. We must also take into account the imagination often informing some one of these rhapsodies as a whole, even when its parts are found to be weak, repetitious, and blemished by inanity or affectation. The absurdities, the crudities, in which Whitman indulges are almost unlimited and all but omnipresent. For illustration, he gives utterance to phrases like this: "I effuse my flesh in eddies and drift it in lacy jags." Following a vague impulse, without depth of reflection, to find new modes of expression, he cries: "Eclaircise the myths of Asia!" "I exposé!" is another of these exceedingly pointless inventions; and we cannot see that the ends of freedom in art, or grandeur of any kind, are served by adopting as the symbol for a writer the term "literat." To call him an "inkrat" would be much more forcible and original. On the other hand, these pages bring to light a mass of vivid and well-chosen though sometimes uncouth epithets. The swimmer is graphically described as swimming "through the transparent green-shine." The "blab of the pave" conveys its meaning accurately and with novelty. What delicate and refreshing aptness there is, too, in this sentence: "The carpenter dresses his plank, the tongue of his foreplane whistles its wild ascending lisp!" Nothing could be better. In the long pieces where much is trite and tame-malformed prose essays they are, rather than poems - there still exists a relation, an order which often brings some very simple and common thought into a light of unexpected significance. But it is sheer fatuousness in the poet, and would be in us, to assume that these two lines, headed ToYou, constitute a poem, or anything but worthless print:

["To You," LG (1881-1882), 18.]

Then, to learn the better side, read Pioneers, O Pioneers, with its steady, splendid, masculine swing, as of a people marching, and its inspiriting sense of comradeship and New World progress; the terse and imaginative lines to the Man-of-War-Bird; or the wonderful sea-shore elegy that begins, "Out of the cradle endlessly rocking." These are full of strength, pure emotion. The same may be said of that night-poem on the death of Lincoln, which contains an impressive chant to Death, the "dark mother always gliding near with soft feet." What could be fresher, fuller of our native coloring, than the picture of spring in this poem?

[Four lines from "When Lilacs Last in the Dooryard Bloom'd," LG (18811882), 258.]

The lines To a Locomotive in Winter, wherein the author hails it as the

"Type of the modern-emblem of motion and

power-pulse of the continent,"

offer the finest embodiment of the grandeur of applied mechanics which American poetry has yet produced. And, throughout, the sentiment of democracy, of manliness, of hope for humanity, is something to be valued in Whitman's work. He sings, "Muscle and pluck forever!" "We have had," he declares, "ducking and deprecating about enough." He aims to increase virility in manners, thought, and writing; and from this effort, whatever the mistakes or limitations of its method, American life and literature are not likely to suffer harm.

But when we considerWhitman's laudation of the flesh, the case is different. It is fitting to recall here the cardinal points of his creed in this regard. He himself says, "Nor will my poems do good only, they will do just as much harm, perhaps more." He claims to be the poet of the body and the soul, and says that the soul is not more than the body, -in this showing an identity of thought with Rossetti; yet he looks forward (in The Mystic Trumpeter) to "a reborn race ... women and men in wisdom, innocence and health -all joy." In his final manifesto occur these words: "I announce the great individual, fluid as 
Nature, chaste, affectionate, compassionate, fully armed . . . a life that shall be copious, vehement, spiritual, bold." All this shows clearly enough that his ultimate aim is good, and that he does not set out to revel in indecency. But the plan he pursues results just as badly as if this had been his purpose; for he makes public and permanent all that which nature has guarded, in both the savage and the civilized, with mystery, holiness, and the delicate, inexorable laws of modesty. Oddly enough this elaborately natural poet breaks one of the deepest and finest of natural laws; and instead of making the body sacred, he despoils it of the sacredness which mankind now generally accords to it. He degrades body and soul by a brutish wallowing in animal matter as animal matter, deprived of its spiritual attributes.

Mr. Whitman prides himself on his healthiness. What is health? Nothing else than the buoyant, normal exercise of physical faculties, in easy unconsciousness of their mode of acting. The moment there is friction, the moment we become conscious of these functions - in heart, stomach, or brain, for example - which ought to be carried on without sensation, health is broken, and sickness supervenes. In like manner, when Mr. Whitman begins to finger over and brood upon the secret processes of certain functions which should work unobserved, he becomes unhealthy. Corrupt he may not be, but he is undeniably morbid. It is his ambition to be "inclusive," to express extremes of good and evil; to fly from one pole to another, in everything. In the sphere of the body he accomplishes this manœuvre perfectly; for his presentation of man's physical being is as often diseased as the reverse. He does not seem to be aware of his "inclusiveness" in this direction. If made so, he might reply with these peremptory words from his Song of Myself:-

[Three lines from "Song of Myself," LG (1881-1882), 78.]

But multitudinousness cannot make the spectacle of his morbidness any more acceptable. It cannot palliate the gross impropriety of which he is guilty, in publishing what is unfit for repetition; an impropriety doubled by the retention of this disgusting stuff in a new edition issued after many years, during which the author has had ample opportunity to free himself from his youthful crudities. Every one imbued with the "primal sanities" must be revolted by this offense, and protest against it. Fortunately, however, the chief damage done will be to the author himself, who thus dishonors his own physical nature; for imperfect though the race is, it still remains so much purer than the stained and distorted reflection of its animalism in Leaves of Grass, that the book cannot attain to any very wide influence.

\section{“Walt Whitman's Poems." [Toledo, Ohio] fournal (January 1882), page number unknown.}

When James R. Osgood \& Co., of Boston, [concluded] to bring out a revised and enlarged edition of WALT Whitman's "Leaves of Grass," they did the best thing possible for American literature, and performed an act of justice towards the most thoroughly original of American bards. WALT WHITMAN is in himself-and in his book, which is himself - the soul of the new and generous continent. He has its asserting egotism, its crude force, its prolific and bounteous vitality. He has the abounding hospitality, the inspiriting positivism of a people that have girdled the forests and chained the mountains and linked to the respectable traditions of a dead past the vital energies of the living present, and who see in the future they shall conquer, the fulfillment of their dearest prophecies and their divinest expectations.

Reading carefully the nearly three hundred pages of "Leaves of Grass" the student, both of literature and of humanity, can but wonder at the strange power that manifests itself in every paragraph. They may criticise the form of expression, may question the 
taste of certain passages, but the overlying grace of the poet and the underlying spirit of the philanthropist animate every part. Here is the vigor and splendor that have called forth the admiration of an EMERSON, a LONGFELLOw and a TENNYSON. It is the largeness and vitality of the primal man - the gigantic and multiplied possibilities of a continent of vast lakes and praries [sic], and rivers and mountains and far-reaching, fertile plains. The effeminate and hot-house reader has no need of its pages. As well could he exchange his satin-covered and rose-scented couch for a bed among the pine boughs of the Sierras. Its living imagery and masterly action is to them both coarse and crude. This Elijah in the wilderness, with his coarse vesture and fiery self-assertion, is quite as much an object of scorn to the dainty esthetes as was the old prophet to the college boys who shouted, "Go up thou bald head!" 79 But the new bard is a prophet too, and as such is willing to wait the slow appreciation that comes to the forerunner in any line. Nearing the conclusion of his volume he says:

[Five lines from "So Long!" $L G$ (1881-1882), 380.]

WALT WhITMAN is the poet of democracy, of strict and absolute equality, who exalts woman alike with man. He is the poet of powerful figures, and there is nothing outside of HOMER and the Bible that equals the splendor of his imagery or the elevation of an occasional passage. The thirty-six pages of military verse under the heading "Drum Taps" contain matchless descriptions of scenes of camp and battle, unequalled by those of any modern writer. "Autumn Rivulets" and "From Noon to Starry Night" are full of indescribable flights. Quoting from the closing poem again, "So Long," the poet prophesies of what shall come after him:

[Six lines from "So Long!” LG (1881-1882), 380-381.]

After all that has been written it is scarcely necessary for us to add that while there are passages in "Leaves of Grass" that for the sake of the immature and casual reader we would gladly obliterate, yet as a sign of the time when a distinctively American school of literature shall arise, vigorous, wholesome, pure, breezy as the praries [sic] and lofty as the Sierras, we welcome WALT WHITMAN and his book. It is a splendid protest against the fine spun and sickly effeminacy of the Amanda Matilda poetry of the American magazine ${ }^{80}$ It is very strong meat but good for vigorous digestion. "Camerado," we return your kiss. Though "disembodied, triumphant, dead," you will dwell forever in the epic of democracy.

\section{G. E. M. "Whitman, Poet and Seer: A Review of His Literary Scheme, Work, and Method." New York Times (January 22, 1882), 4.}

[. . .] It has been shown what Whitman has striven to be and to do. No one could be more in sympathy with what is real and vital in his scheme than the present writer is. But conception is not execution, and Whitman's plans are infinitely better than his work. One should hardly need to be told, in an epoch so critical and so keenly alive to humor as our own, that mere brag and buncombe and assertion do not pass unchallenged as strength; that noise and strain are not power; that extravagance is not inspiration; that orphic talk is not prophecy. It is right, of course, to credit Whitman with sincerity, with the honesty of his convictions. Many are loth to own this much; though no person, minded to learn and see the truth, can read this poet's work through and fail to feel its occasional fire and stir. Whitman writes, at his best, with deep emotion and conviction. He rises at moments to heights of poetic insight and inspiration. There are a fine lyrical sweep and a genuine epic breadth in a few of his poetic rhapsodies. This would be more clearly felt if his work were not so thickly rutted with that insane kind of nonsense which some devoted worshipers persist in calling great thought and great poetry. Whitman's work is like a rich garden embedded in weed. Flower and weed are 
here inextricably blended. The brag, and assertion, and wrench of this American seer will never be accepted above their value by those who know that the finest art is a result of the finest sifting of thought, intelligence, emotion, and vigor. Art, in a high sense, is the test of strength, not the sign of weakness. In placing himself above art, in confounding the ability to discriminate and shape with mere technical dexterity, Whitman puts himself on the wrong side of nature. This would not be a matter of much moment, it is true, if his clamorous upholders were not seemingly bent upon elevating his method to a doctrine. The poet who labors with no fetters runs to chaos. Nature is like true art in this; it creates within laws. What is more simple and lovely to the sight than a flower? Yet consider the forces that make the flower, the elements that are parts of it, the intricacy of its mechanism; and compare these with the exquisite grace and appropriateness of its outward form. It is a rule in nature that all chaos shall tend to form and harmony; the universe is, when looked at singly, as simple a thing as the cup of a lily. Whitman and writers with his disposition pretend to be the true sight-seers of nature, while they awkwardly reflect its lawlessness and complexity. The harmony and the simplicity of nature are not shown in Whitman's poems, even when these are most true and suggestive. To teach a doctrine of lawlessness, therefore, is about the least intelligent project that his blind followers have tried to carry out.

Destructive criticism might be applied to Whitman's little understood and much discussed Americanism. There is certainly a thing which may be called Americanism. This is frequently flashed out in these poems, but it is not lucidly expressed. At times it amounts to palpable rigmarole, which no one but a jaded European nurtured amid the tiresome and mournful strife of the Old World could mistake for the real thing. Our country, it may be explained, represents certain new ideas of nationality and advancement. It represents at the present moment, more strikingly and splendidly than any other land under the sun does, scientific progress as opposed to revolutionary progress. It is a land to which all the currents, and longings, and peoples of history move like rivers converging to one stream and one mouth. It is the mother of individual liberty, freedom of thought, and peaceful labor; a land, therefore, in which the researches of the world are most nobly welcomed, which leads the nations toward a righteous justice, which gives a home to all aliens. What progress may do will awaken here, above all, response and sympathy. Our country illustrates, in brief, the advancing spirit of the nineteenth century. This is certain and clear. On the other hand, we are not a people of the old rugged and uncivilized sort. We are not like those for whom Homer sang, and we stand in no need of a Moses nor of a Mohammed. We are not chiefly - as some of the exuberant persons on the other side of the Atlantic seem to think-hewers of wood and drawers of water. Our lasting honor is - and this is certainly overlooked - that our pioneership is above all intellectual. A ripe and vigorous civilization is at the heart of the land. The rabble and the unthinking mob do not represent our real vitality and progress. It should be plain, then, that our country has a peculiar individuality and a decisive mission. It is a strange union of past, present, and future. A poet like Whitman - who rhapsodizes more often than he thinks and sings - is sure to suggest something of our individuality and he has, without doubt, gone further than other poets. But his conception of our land and people is full of inexactitude, full of false idealism, and loaded with extravagance. There is too much of the red-shirted Hoosier about it. ${ }^{81}$ It comes close at times to the spread-eagleism of our astonishing orators, and to the fraternity of the bar-room. Its permanent merit is that it reflects, after all, something of the free and creative sprit which is the spring-source of our life. It tells us of our liberty - a small matter which our ancestors strove mournfully through hundreds of years to win, and which, now that we have got it, we are apt to prize rather loosely and humorously.

All that has been written above might be illustrated by columns of extracts from "Leaves of Grass." But others may pick these out for themselves. I have simply sought to show 
broadly that there are radical sins and false premises at the very basis of these poems. Whitman's theory of life and humanity, and his absolute lack of sound artistic instinct and taste, lead him into extravagances which have as much relation to strong and true song as a fishmonger's bawl has to the melody of birds, or to the musical roll of water upon a stretch of shore. They lead him, also, into some monstrous excesses, and the poems comprised in "Children of Adam" are naked exhibitions of these. The poems in question have been struck by many lances, denounced by many mouths. Good ink has been wasted upon them. They are over-Whitmanish and not beautiful. In these fleshly diatribes the poet sets out to "make illustrious" that which is not commonly discussed in sensible and good company. He throws off his shirt, so to speak, and cries lustily, "Behold, I am Walt Whitman, I am moral." Poets have sung with more or less sense of creation-Whitman goes down to the actual facts. This may be moral. It is intended as an illustration of the highest morality. But it is - unless the world has gone wrong since the beginning of time-indecent and vulgar, not one degree above the loose talk which is, unfortunately, common enough in low places and high. As to its pretentious morality, that does not deceive, and it is solely justified in the poet's inner consciousness. The things here uttered by Whitman may be, unquestionably, thought of chastely, but they cannot be written down and seem either pure or modest. At best, they are coarse commonplace, imposed upon the reader with prophetic earnestness. At worst, they are unlawful exposures of the person.

It is a relief to turn from this fustian to the "Song of Myself," which is a healthy expression of vigorous humanity and imaginative egotism - a poem in which the relation of a man to his fellow-creatures, and to his world, and to the universe, is set forth at moments with real power of manner, breadth of sympathy, and original feeling. The contradictions in this poem are clearly the result of forethought and design, for it is the good and bad in a man, according to Whitman, that awake the unchecked energy of his nature. "I resist anything better than my own diversity," he says. And he adds, with rare courage: "I accept Reality and dare not question it." There is the right sort of materialism in the following chant:

[Ten lines from "Song of Myself," LG (1881-1882), 46.]

Here is another passage from the same poem, and in the poet's less rhapsodic manner:

[Eight lines from "Song of Myself," $L G$ (1881-1882), 54.]

There is, of course, the usual bulk of orphic and oracular utterance in the "Song of Myself," and much of this is solemn commonplace merged into a species of transcendentalism. Its meaning is not always clear. But, on the other hand, the poetry in this song has strength and reach. The following verses were admiringly quoted by Prof. Clifford in his essay on "Cosmic Emotion:" 82

[Fourteen lines from "Song of Myself," LG (1881-1882), 72-73.]

In the "Song of the Open Road," "Song of the Answerer," "Song of Joys," "Song of the Exposition," "Song for Occupations," and in other poems more or less identical in spirit with these, there is expressed with undoubted sincerity and vigor, entire sympathy with the moods of nature, with the longings and work of mankind, and with the various sides of life. They are singular combinations of triviality, prosiness, poetic feeling, and arrogant personality. They lack, above all, the fine simplicity and clear brevity of songs meant for the popular ear and heart. Yet they have an intensely modern and popular spirit:

[Seven lines from "Song of the Exposition," LG (1881-1882), 162.]

That is Whitman at his best, free of verbiage and pretension, and with something to say worth saying, with honest emotion and good sense. The same lyrical sincerity is felt in the invocation to America, ("Song of the Exposition,") when he speaks of "the common indivisible destiny for all." The "Song of the Redwood Tree" is throughout a fine poem, full of brain and freedom, and the real hope and faith of our time are simply expressed in the "Song for Occupations:" 
[Three lines from "Song for Occupations," $L G$ (1881-1882), 171.]

There are truth, ardor, and inspiration in some of the songs included in "Bird of Passage," the best of these being "Pioneers, Oh Pioneers," which has a rugged rhythmic movement uncommon in Whitman's writings, although the opening to the "Music of the Storm" is equally fine, while some few other passages which have an exceptional quality of sound and rhythm are quickly remarked. The tenderness, pathos, and manhood in the series of poems called "Drum-taps" are, perhaps, the most natural and sympathetic touches in Whitman's copious and curious work, and it may be said of this work, finally, that Whitman himself marks their surest claim to attention in some of his closing verses:

[Five lines from “So Long!” LG (1881-1882), 382.]

[ ... The permanent value of these poems, in fact, is to be sought in their two clear merits: in their modernness, breadth, and originality of purpose, and in their presentment of a strong and fresh individuality. The aim of these poems, and the man behind them, are more distinctive than the poems themselves. "Who touches this touches a man" is an assertion which is felt to be perfectly just. The book-judged by the standard of all great books-falls far below greatness. There is no single poem in it which could be safely compared with any single great poem in our language. Whitman's work is fine in flashes, in strong passages, or in sudden descriptions. It is weighed down, on the other hand, with extravagances and excesses like those already spoken of, with a mass of illdigested learning, with long stretches of windy prose, with violent and insecure handling of deep themes, with all kinds of crudity and with a manner which is seldom effective and impressive. This manner has been considerably praised by some for its originality and free musical movement, and it has been called by others a formless manner. But it is surely not formless, since it has a perfectly definite form, deliberately chosen and full of artifice. Its rhythm, however - when it has a rhythm - is perfectly commonplace. The prose of Fénélon ${ }^{83}$ and Carlyle and the verse of the Bible have incomparably more poetic color, strength of language, melody and harmony of sound, than Whitman's verse at its best. The laws of natural verse are here ignored, and the result is, of course, unnatural. Compare this verse with the unrhymed movement of Shakespeare and Shelley, with that of Wordsworth's sonnets and Keats's odes, and with the rhythmic freedom of Swinburne's "Song Before Sunrise;" or compare it with the Biblical verse in the Song of Solomon. As to its utility as a medium for the transparent expression of high thought, compare the most intellectual of Whitman's poems with Tennyson's "In Memoriam." These comparisons will serve better than criticism - to persons at least who have ears open to musical sound and minds open to conviction. Language is to the poet what color is to the painter, and great and genuine thoughts should have great and genuine expression. To master language, to garment genius fittingly - this is the art of the poet, and this is the art which Whitman and some others appear to despise. It is art that divides truth and passion from commonplace and rant, that draws a sharp line between sustained strength and hyperbolic bluster. Whitman, however, deserves our deepest gratitude for the stand he has taken, in face of this present age, in the fore of its creative work of reconstruction, in front of its iconoclasm and science. Most of the poets-especially the American poets - are probably against him, but the spirit of our time is not to be quenched by literary conventions, and the strong minds of our time are with him. His courageous appeal for more knowledge and still more might be fitly contrasted with the sentimental snivel of those timid creatures who weep at the passing of the good old days. These sad persons are typified by the æsthetic Mr. Wilde:

[Twelve lines from Oscar Wilde's "The Garden of Eros.”]

Those two last lines are worthy of Bunthorne; but they show about as much unconscious humor as most of Bunthorne's contemporaries exhibit when they begin to vent their feelings about romance and science. ${ }^{84}$ Weigh such words in the balance with the 
wise words of Prof. Clifford: "To some minds there is hope and renewing of youth in the sense that the last word is not yet spoken, that greater mysteries yet lie behind the veil. The prophet himself may say with gladness, 'He that cometh after me shall yet be preferred before me.' But others see in the clearer vision that approaches them the end of all beauty and joy in the earth; because their old feelings are not suited to the new learning they think that learning can stir no feelings at all." ${ }^{85}$ In his article upon "The Poetry of the Future" (published some months ago in the North American Review,) Whitman wrote these words, which are, I believe, good prophecy: "Science, having extirpated the old stock fables and superstitions, is clearing a field for verse, for all the arts, and even for romance, a hundred-fold ampler and more wonderful, with the new principles behind. Republicanism advances over the whole world. Liberty, with Law by her side, will one day be paramount - will, at any rate, be the central idea. Then only-for all the splendor and beauty of what has been, or the polish of what is - then only will the true poets appear, and the true poems. Not the satin and patchouly of to-day, not the glorification of the butcheries and words of the past, nor any fight between Deity on one side and somebody else on the other-not Milton, not even Shakespeare's plays, grand as they are."

\section{The Springfield Sunday Republican (September 24, 1882), page number unknown.}

Walt Whitman's new publishers, Rees, Welsh \& Co of Philadelphia, are evidently cheap sensationalists, quite unfit to issue a great work like "Leaves of Grass." It is to be regretted that Whitman had not the patience to wait for some firm of consequence to take up the task Osgood feebly laid down. The Philadelphia firm advertise in this fashion in the Philadelphia Press:-

"'Leaves of Grass,' by Walt Whitman, is not an agricultural book in the haymakers' parlance; but it's a daisy, and don't you forget it."

The Critic justly says that "this is a worse blow than that dealt by the Massachusetts Dogberry." ${ }^{86}$ These fellows are apparently gamins out of their place. ${ }^{87}$ Nothing could be more vulgar than their adoption of "nigger minstrel" slang for so noble a work, and it can only be explained by supposing that they take Anthony Comstock's ignorant estimate of the "Leaves of Grass" for gospel, and count on the patronage of the obscene. ${ }^{88}$ This seems a great pity, but perhaps it is not so, for it may falsely attract to Whitman through their meaner appetites a class of readers who need to learn his great lessons. Suppose that any one with brain enough reads this great passage,--remembering that Whitman, in his first person, represents the essential man:-

[Forty-three lines from "Song of Myself," LG (1881-1882), 71-73.]

This must be read, as it is written, in the grand manner, and the reader who does not realize that his guide casts behind him the centuries and exhorts him to a new lookout into eternity had better read no more. There has been no more magnificent attitude of command taken than Whitman takes in these utterances, and sustains in almost all that he has written. The trivial person has nothing whatever to do with Whitman. 

11,1882 ), page number unknown.

NO. XIX.

To-day my soul is full of the love of the body. "Out of the fullness of the heart the mouth speaketh;" and so to-day, O mothers, I ask you to listen to the wonders and the beauties of the body.

[Five lines from "I Sing the Body Electric," LG (1881-1882), 85, 86.]

Nurture, cherish and love your bodies, for in them lies the seed of the mind, and on them depends the quality and beauty and strength of the mind. For years and years has this love and worship of the body been growing and developing in the foremost minds of the race. To-day America's new Poet is singing strong, sweet, heart-invigorating songs to his brothers and his sisters. To-day ears are opening, one by one, to these tuneful melodies, and hearts are thrilling in throbbing responses to the echoes of truths so sweet, so simple, and so harmonious, that the wonder is how for all the years past we have let them be sung in vain and unheeded.

Many are the books I have read and recommended to the world of seekers for knowledge, truth and wisdom; but now I come with one that has but a doubtful fame as the world goes, but one whose words thrill, enthuse, and stir with a responsive echo such as few poets have been enabled to arouse by their works. This wonderful book is "Leaves of Grass!"

Be not startled that I-Elmina, the Quaker Infidel—ask you to take into your homes a volume that has been tabooed, ridiculed and condemned by so many. I do it with a full knowledge of its innate worth and purity. Alone here in the early mornings have I sat conning its entrancing pages - rising refreshed and invigorated as from a draught of freshest water from some wild mountain torrent, a new life in every limb, and a new spirit in every thought. Take, $\mathrm{O}$ mothers, a page of Walt Whitman for your morning prayer, and you will begin the day with strong, pure aspirations, and a heart attuned to all that is good, true and beautiful-all that is vigorous, natural and elevating.

[Four lines from "Song of Myself," $L G$ (1881-1882), 31.]

I feel that I can not do better justice to the book than to give an extract from a lecture on it delivered by one who has himself the soul of a poet, and the heart of a man who loves his race-George Chainey, the lecturer of Paine Hall. ${ }^{89}$ This one on "Leaves of Grass" I heard him give myself, while I was in Boston, and it determined me to buy the book; and now I feel that I want every mother in the land to own the volume and love it. To own it and read it will be to love it. I wish I had room to quote all of Chainey's lecture, but a part must suffice.

"Whitman found that he had to chant the glory of the body as well as that of the soul. To him the two are identical.

[Two lines from "Starting from Paumanok" and five lines from "Song of Myself," LG (1881-1882), 26, 49.]

"In his sight, no part or passion of the body is to be slighted or regarded as vulgar. In doing this, he finds it impossible to leave out of his poems the element of sex. I know of nothing that we need to pay such heed to as to what he has to say on this subject. Never will the world be saved from its sickness, pain, and despair, until we take up this element of human life, and treat it as frankly, purely, and reverently as he has. As he says:

[Six lines from “A Woman Waits for Me," $L G$ (1881-1882), 88.]

"Of course, in the treatment of such a subject there must be expressions used that impure minds will prostitute to impure purposes. The fairest, purest, and most beautiful things on this earth are so violated. As Hamlet said to Ophelia, 'Be thou as chaste as ice, as pure as snow, thou shalt not escape calumny.' 
We all know that depraved passions sometimes break down all the barriers of virtue, and do violence to the most maidenly chastity. It is the same low order of morals that thus seeks to drag into the mire the noblest thought and purest purpose of the best benefactors of humanity. The spirit and purpose of Whitman are clearly revealed in the only reply he has yet made to his maligners and persecutors. He tells us that this subject of sex has hitherto been treated of only in two ways. The first, the conventional one of total repression and silence of good folks, creating the feeling that what can not be spoken of must be vile, and so, by covering over disease and depletion, increasing the world's woe. The second is the coarse, vulgar way of speaking of these things that obtains current in many masculine circles, wherein men lose their respect for women, and hold in low esteem their own manhood through learning to take delight in vulgar stories.

"Alas! we all know that this is true. Thus, the parlor and the barroom have formed a partnership for the propagation of vice. The first doubt lodged in my mind against the claims of the Christian Church and ministry was the first time I spent an evening in the company of three ministers. I expected innocently that the conversation would be on the subject of religion and touching the advancement of the Church. To my surprise and horror, they spent the whole time in regaling one another with smutty yarns. I never was made to blush so much for the company I found myself in before or since. I soon found, however, that this was quite a common practice in the ministerial profession. At campmeetings, while one or two of their number are thundering at better men and women than themselves to repent or go to hell, the rest are secluded in their private tent, regaling one another in this fashion.

"Thinking what he might do to reform these perverted tendencies, Whitman concluded that the time had come for a full and frank statement, in loftiest and most earnest manner, of the relation of sex to the health, sanity, and purity of the human race. He desired to connect it with the highest ethical expression of nature and humanity. How nobly and grandly he has done this, none but those who read and love his poems can feel."

I could give you a long array of worthy names indorsing and eulogizing this beautiful work, but instead of the names I give you from the book itself.

[Fourteen lines from "Song of Myself," $L G$ (1881-1882), 33.]

I shall be glad to fill orders for this book of books. Grander and purer than all Bibles - a book that shall make lovely women and stalwart men, and sweet, happy, healthful babes.

\section{Other newly discovered reviews:}

"Walt Whitman: The Man and His Book-Some New Gems for His Admirers." Boston Post (November 2, 1881), 2.

“Walt Whitman's Works." New York Commercial Advertiser (November 9, 1881), page number unknown.

"Walt Whitman." Scottish Review 2:4 (September 1883), 281-300.

Walter Lewin. "Leaves of Grass.” Murray's Magazine (September 1887), 327339. 


\title{
SPECIMEN DAYS \& COLLECT (1882)
}

\author{
"Walt Whitman's new book. . ." Boston Evening Transcript (November \\ 1,1882 ), page number unknown.
}

Walt Whitman's new book, "Specimen Days and Collect" is a literary curiosity made up of extracts from journals and diaries of different years; disjointed bits of criticism, argument, reminiscence, description and speculation, with comments upon persons, events and things; fragments of essays and correspondence; scraps written for newspapers; samples from his commonplace book, and what is quite as interesting as anything else, a brief biography of himself. Added to this, in a second part of the book, are "Democratic Vistas," the long essay written for one of the reviews some years ago; the long preface to the first edition of "Leaves of Grass," published in 1855; "Poetry Today in America," "The Poetry of the Future," and "A Memorandum of a Venture." An appendix contains several stories written in the author's youth, and his two first attempts at poetry. There is no trace or suggestion in its pages of what caused his volume of poems to be read out of decent society. The first part of the volume is mostly given up to war reminiscences, and is full of interest.

\section{"Books. Specimen Days and Collect." Philadelphia Quiz (November 2, 1882), page number unknown.}

This book is in two parts; the first part is devoted principally to the author's experience in Washington, during the War, visiting the sick and wounded. His kindliness of heart and broad humanity are manifested on every page, and one cannot but regret that he did not have the strength, or the inclination, or both, to make a continuous narration of it, instead of the sketchy little notes with which he has furnished us. Besides these War episodes, he gives us an insight into his love of Nature, and the keen delight he experiences in the open air, in the sun, in the oak, in the full starr'd nights, the common earth - the soil and the skies. Indeed, these short sketches contain material that would make the fortune of a commonwealth of rhyme-makers. He also gives us his impressions of Carlyle and Emerson, of Longfellow, Whittier, and Bryant, impressions evidently softened by age, for his present opinion of Carlyle is not what, we would have looked for in Walt Whitman, and one not at all consistent with the spirit of his "Democratic Vistas" in the "Collect."

He gives us, likewise, an appreciative critique on Jean Francois Millets's [sic] "Sower," "the Diggers," "the Angelus" and "Field-People Reposing." A view of these pictures certainly has the effect of making the blood boil, and the heart fire-up with much the same sort of flame as burned in the hearts of the Jacquerie. One could have foretold the French Revolution from these pictures, had they been painted in time.

$\mathrm{He}$ also reveals to us his departure from his previous customs, as depicted in the horrible juvenilities in the back of the book. It is a pity the book was disfigured with them. He gives us therein a frightful picture of intemperance, much as a ten-year old Cadet would have done. But on page 188, he owns to draining "big, brimming, fill'd-up champagne-glasses ... to the last drop."

The second part, or "Collect," is much the more elaborate portion of the work. In "Democratic Vistas" he gives a thoughtful review of our country, as to its literature, and 
its political life. Though the acknowledged poet of the "People of these States," he does not take a rose-colored view of them, by any means, politically speaking. He says:

[A half-paragraph from "Democratic Vistas," Specimen Days E Collect, 210.]

Yet of the people he does not despair. Their heroism in the camp, in the battle, and in the hospitals, has convinced him that the material for a great people is at hand. But they must be awakened. Reformers are needed, and though they speak rashly, eagerly, and often inconsiderately, their ill-balanced enthusiasm in the right direction is necessary to disturb the "inertness and fossilism of human institutions." This direct exposition of the lamentable defects in our body-politic, is timely, just when the leaven of improvement is beginning to work, - with what result, time only will show. Whether our present system is able to evolve a better state from itself, or whether an entirely new, or at least, a greatly changed form will be necessary to accomplish the desired result, it is now impossible to tell. That our political future is at all doubtful we have no reason to suppose. Though we may go back for a time, though corporations and political bosses may hold our people in bondage for a while, the spirit of civilized communism and socialism is not far enough removed from the minds of our American laboring classes, but a revolution may be inaugurated at any moment. As Walt Whitman says, "practically, strikes are attempted revolutions, and the Revolutionary War, and the French Revolution were strikes."

Walt Whitman attacks, more particular[1]y, our literature, and in fact, all literature. He finds Shakespeare and Scott the poets of the great lords - nowhere are there poets of the people. But it seems to us he fails to recognize at their true value, the poetry of the novelists. He dislikes romances, and does not give them any place. Yet Dickens is as clearly the poet of the people as Walt Whitman, himself. And Victor Hugo, in the French, and Auerbach, in the German. But his greatest grievance is that there is no American literature, as such. But he again is unjust in a measure. Of course, he has no humor, and can recognize no use in it. But Artemus Ward is as redolent of the American soil as Walt Whitman, and while he is not, in any sense, a champion of the people, but rather their satirist. Mark Twain, inferior, it is true, but yet American throughout, is thoroughly republican in thought, tendency and expression. So, also Bret Harte, inefficient and ultra-sentimental, and often weak and incomplete. But granted that we have no distinctive American literature, with the exception of Walt Whitman himself, it was six hundred years after the English nation was formed before Chaucer, the first of English national poets, appeared. And what a long interval elapsed before a great one followed him. And thus, while the nation was untrammeled by traditions and forms. We, who have not assimilated the numerous ingredients furnished us by foreign countries, are not yet even a nation-perhaps, have not even a stable government. We have inherited a rich literature, which we have imbibed in infancy, which is taught in our schools as the model of all that is desirable in thought and style. To strike out a vigorous Republican poem in a country that persecutes the Chinese, that stigmatizes one day the Jews, another the Catholics, and another day some other race or religion, would be almost a sarcasm. It is not a Republic where wealth purchases immunity for crime, where the sheriff furnishes desirable juries, and the prosecuting attorney takes care of the criminal. The administration of justice must be improved, to the end that the voice of the people will be heard - that the government, through its officers, will represent the will of the people. Then, and then only, will we become a nation with national characteristics - and not in the meantime, a colony of Great Britain, speaking the same language, singing the same songs, and generally remaining the unconsidered minor performers in the theatre of English literature.

But it takes time for all this, and we have reason to be proud that only eighty years after the sounding of the tocsin of American independence, we have already had our Chaucer-Walt Whitman. 


\section{“Walt Whitman's Prose.” Boston Advertiser (November 4, 1882), page number unknown.}

Walt Whitman's “Specimen Days and Collect" is not, as its name might be supposed to imply, a book of religious exercises. It is a miscellaneous gathering of his prose writings, early attempts, bits of letters, extracts from note-books and diaries, and what not, - a pretty miscellaneous collection, without much connection except the author's personality, which looms up immensely through it, as it does through everything else he has written. The stories written while he was still in his teens are so melodramatic and unreal, that they would be unworthy of notice were it not for the premonitions they give of the author's powers. They have an intensity that almost reaches imagination, and they show also marked tendency to dwell upon the horrible. Out of nine tales seven are death-scenes, most of them with horrid accessories of cruelty and hate and lust. The melodramatic element in them belonged to his youth, and was entirely outgrown as his strength developed, but the brutal side of life has always retained a painful fascination for him. In the later writings in this volume he appears to much better advantage, notwithstanding their heterogeneousness. The passages about the civil war (he was in the hospitals through the greater part of the war) are very vivid, horribly so at times, with a fiery light like Carlyle's. The description of the death of Lincoln might have been a study for the "French Revolution." There is a milder description of Washington after the great defeat at Bull Run.

He had naturally a warm appreciation of Carlyle, and writes well of him. Emerson is too good and too beautiful, with too little of the wild bull to satisfy him. Occasionally he is extremely unfortunate in his comments, as when he says that it is as a critic and not as a poet or artist or teacher that Emerson excels - than which nothing could well be more erroneous. He had a keen appreciation of Carlyle's worship of force, and possessed his power of vivifying details, and even something of his style. He has a freshness and manly vigor that the dyspeptic Scotchman did not share. But he has shown none of the capacity for concentrated and prolonged effort that is essential for great work, and none of the aspiration for, or even conception of the ideal, which raises a work into art and made Carlyle a leader among men. In this volume Mr. Whitman adheres to his old theories, but his taste has grown purer, and there is comparatively little to offend.

\section{“Specimen Days and Collect.” The American (January 6, 1883), 203.}

Many persons, no doubt, will entertain the opinion, after reading Walt Whitman's "Specimen Days and Collect" (Philadelphia: Rees, Welsh \& Co.), that his prose is more poetical than much of his poetry. Into this volume he has gathered fragments of writing, some of which were produced as long ago as 1860, and all of which are illustrative of his thoughts and his experiences in the woods and the city, in the camp and the hospital, in his home and in his journeyings. Mr. Whitman was employed in Washington during the entire period of Rebellion, and the most entertaining passages in the volume are those in which he draws pictures of the events of that time of excitement and anguish. No doubt, the effect of these upon him who reads them will be to create a warmer feeling of regard for the man who wrote them, and to soften any severe judgment that has been passed upon him as the author of less satisfactory compositions. It will be perceived, also, that Whitman herein shows himself to be truly a man of force and originality, who not only sees things clearly, but possesses the skill to express, with precision, thoughts which other men find it difficult to formulate. We are confident that the volume will find favor with thoughtful readers. 


\title{
THE POEMS OF WALT WHITMAN (1886)
}

\author{
"Whitman for the Drawing Room." Papers for the Times 22 (April 1886), \\ 181-185.
}

MR. RHYS and his publisher surely meant well when they decided to issue a volume of selections from Leaves of Grass. ${ }^{*}$ The book is not intended for the confirmed admirers of Whitman, for they will be satisfied with nothing less than the complete work, and it can be of small benefit to his opponents. These opponents may be divided into two classes: persons who honestly object to Whitman's plainness of speech, because they regard it as unnecessary and unfitting. They say there is a time to be silent, and though no part or function of man if properly treated is disgraceful, there is no reason why all should be publicly exhibited. Whitman, they say, has erred in judgment. These persons we can respect; their opinion is honest and intelligible. The other class we cannot respect. It consists for the most part of hack writers to the press who think it no portion of their duty to know anything of the works they are paid to reviewt and of the patrons of these scribes, the retailers of literary small-talk in British drawing-rooms, whose god is Mrs. Grundy, ${ }^{90}$ and whose sole virtue is to appear respectable. No doubt a good many of these will buy the Selections, Whitman's reputation among them having, hitherto, been questionable; just as an actress of easy virtue draws them to the theatre, though her histronic [sic] powers are nowhere and her manners on the stage the pink of propriety.

These persons will certainly be disappointed, not only with the selections which Mr. Rhys has prepared, but with the original and complete volume itself. They will not find in either what they want. The speech is plain and unveiled, but cleanly. Veiled obscenity in the shape of a joke, a spicy story, or the reports of criminal cases in the Pall Mall Gazette are more to their minds. The second-hand bookseller knows their taste well, and when he labels a volume "curious" adds fifty per cent. to the price. There are even certain fellows of the baser sort whose trade consists in lending out willfully obscene books to these "respectable" people for their private reading.

Their private reading, to be sure! for in public nothing - unless it be the Pall Mall's leading articles - could exceed the solemn piety and hatred of everything gross which they exhibit. Nothing that would bring "the blush to the maiden cheek" can be tolerated by them. They are above all else zealous for the virtue of their womankind, just as if they had never laughed over the story of a treacherous seduction, or participated in one themselves. Not, indeed, that they object to being described as "knowing dogs" or "men about town," for this rather enhances their reputation among some of their fair friends. The British matrons are eager enough to give their daughters in marriage to them, regardless of the prior claim which some other young woman may have, but which she cannot enforce because it has not received a priestly blessing; nor are the maidens themselves touched with remorse or with sympathy when they usurp the place. Mrs. Grundy does not require it so to act as they do is respectable, and there is nothing more to be said or done.

*The Poems of Walt Whitman (Selected), with Introduction by ERNEST RHYs. Walter Scott, $1 /$-.

†For instance, here is a Saturday Reviewer, boldly denouncing Whitman, who does not even know the name of Whitman's book. Blades of Grass, he calls it. 
Yet even respectable people need relaxation sometimes, and to test their private morality you must ascertain why the gentlemen guffau over their wine, and the ladies in the drawing-room - before the gentlemen arrive - titter hysterically behind their handkerchiefs. Mrs. Josephine Butler, ${ }^{91}$ many years ago, stated publicly that she had given up dinnerparties because she could not endure the after-dinner talk of the drawing-rooms.

These are the people who most vigorously condemn as immoral the plain spoken, cleanly minded Whitman, and while, as we have said, they will very likely buy Mr. Rhys' book, there is no hope that it will benefit them. Possibly, however, a copy here and there will fall into the hands of some man or woman who, thus becoming acquainted with the "good grey poet" for the first time, will make good use of the opportunity. To many Whitman has, hitherto, been only a name; to some not even that. Perhaps the little volume has a mission to them.

Coming now to the book itself we find something to condemn and something, also, to praise. The portrait is no better than a caricature. The Introductory Notice is interesting, but it would have been more satisfactory had its author kept clear of ungraceful affectation in style. "Depicture" and "invigorative" are not elegant, and "most immediate" is something worse. However, in these cases we are able to gather what the writer means; but occasionally it is impossible. What, for example does he mean by this: "Born on Long Island or Paumanok, its Indian name, by which he always calls it, in the State of New York, of a stalwart race of farmers, in 1819, the freedom of sun and wind was his, in a wide country side, with rising hills around, and the sea that he has sung so affectionately, with such deep sympathy, so that its harmonies seem to have subtly informed his poetry, close by." In short, if we may presume to give a word of advice to Mr. Rhys it will be-avoid, as you would poison, the mannerisms - not to say vulgarisms of the so-called æsthetic school. The best written passages are those which, obviously, are in the author's natural style. Mr. Rhys is a hearty yet discriminating admirer of Whitman. His reference to Burns is very happy, and there is much justice in his remark that the advance Whitman has made "is a great one, beyond a doubt. The only danger is that in accepting this new tendency we may neglect the great virtues of past modes. Always the salvation of all art expression lies in the perfect adjustment of the new with the old." Mr. Rhys does not note the real advance which, as it seems to us, Whitman has made beyond his predecessors, namely in his sentiment toward death. Others have treated death as a "dread monster," an enemy, or have simply ignored it. Even Goethe said "Death is something so strange that, notwithstanding all experience, one thinks it impossible for it to seize a beloved object; and it always presents itself as something incredible and unexpected." ${ }^{92}$ Whitman alone hails it lovingly, as a friend:

[Twelve lines from "When Lilacs Last in the Dooryard Bloom'd," LG (18811882), 260.]

"The method of selection adopted in preparing the volume," remarks Mr. Rhys modestly, "has certainly not been scientific or very profoundly critical." The task of selection in the case of Whitman would undoubtedly have peculiar difficulties. "The limitations of the average run of readers have been, as far as could be surmised, the limitations of the book." ${ }^{93}$ All things considered, Mr. Rhys has chosen well, but that the Song of Myself, containing as it does some of Whitman's finest as well as his most characteristic work, should have been wholly omitted, is singular. It is here he gives his key-note:

[Three lines from "Song of Myself," $L G$ (1881-1882), 29.]

Here, also, occur such grand passages as the following:

[Twelve lines from "Song of Myself," LG (1881-1882), 32, 43.]

Another omission which we can hardly approve is The Singer in Prison, but after all, something had to be omitted, and the editor's task was by no means an easy one. He has not omitted, as some editors might have done, In a City Dead House and The Flight of the Eagles. ${ }^{94}$ The former touches on a subject treated by Hood in his Bridge of Sighs, 
but grandly not morbidly. The latter is as artistic as anything Whitman has written. Mr. Rhys and Mr. Scott deserve credit for this effort to popularize Leaves of Grass. When may we hope to see a complete edition at a shilling?

\section{NOVEMBER BOUGHS (1888)}

\section{"November Boughs." The American (November 24, 1888), 91.}

This latest collection of Whitman's work is mainly prose; only about twenty pages out of the one hundred and forty being occupied by pieces in the form of poetry. Yet, as these latter are nearly all very brief, many of them not exceeding a dozen lines each, there are many titles,- no fewer, indeed, than fifty-seven. The prose is also divided into more than twenty articles, and several of these are sub-divided. Altogether, the book is made up of gleanings and gatherings, the work of one who stands near the final exit.

Of the poetry, which is grouped under the general title of "Sands at Seventy," we do not need to present here any critical notice. Not only is there a settled opinion, one way or the other, in the minds of most literary people on the question whether Walt Whitman's metrical work is truly poetry, but our readers have quite recently had the opportunity of enjoying a very full discussion of that subject. Let the final decision be as it may upon the one point whether his verse is materially injured by its irregularity of form, it is certain that there is in it a vital spirit, poetical in its nature, and that this has found, and doubtless will continue to find, its circle of admirers. The examples in this volume are marked by characteristics with which those in his previous books made us familiar, with the exception that none of these incur objection on the score of propriety. They show perhaps, less force, less ruggedness, less of the extreme Whitmanesque individuality, while they incline more to retrospection, and a vein of chastened sadness. There is no rhyme, of course, but occasionally there is a verse almost smooth in metre, and regular in the flow of its rhythm, as for instance this "After the Dazzle of Day":

["After the Dazzle of Day," November Boughs, 22.]

And there are others equally as notable in this respect, of greater length: we quote this partly on account of its brevity.

The prose papers include a long one, placed first in the book, (the poetry follows it), entitled "A Backward Glance O'er Traveled Roads." In this he reviews in fourteen pages, his own work, explaining his purpose, his plan, his form of thought. He justifies the much,- - and as we have always held, justly, - criticised lines in "Leaves of Grass," and insists that they shall not be elided in future edition, "if there should be such." Others of the papers refer to his hospital experiences, to Shakespeare, Burns, and Tennyson, to Lincoln, to Father Taylor the Boston preacher, etc., etc., all notable in style and matter, and some extremely vivid and striking. At the last he gives an extended sketch of Elias Hicks, the Quaker preacher of Long Island, whom he knew in his boyhood, and whose character he highly appreciates.

This is a very important addition to the list of Whitman's books. The matter is so compactly inserted that there is much more than might be supposed. If it were spread out as often is done, the poetry alone would fill a thin volume, while another could be made of the Notes on Elias Hicks. The "Backward Glance" is entitled to an attentive reading, as a statement, final no doubt, of his own view of his poetry, and this alone deserves a much more careful and elaborate consideration than we have been able to give in this notice. 
"Walt Whitman's Latest Work: 'November Boughs' and Estimates of Its Distinguished Author-The Poet's Grounds for 'Leaves of Grass'Books and Authors." The [Chicago] Daily News (February 9, 1889), page number unknown.

With "November Bough" the work of Walt Whitman may be considered finished. The age of the poet (he was born in 1819), his infirmity, the suggestive title of the volume, and the character of its contents all indicate that it is the final word, the last farewell, of one who awaits death with the tranquil mind and the clear vision of the prophet.

Should the life of the poet be spared yet a few years he may, and doubtless will, add something to what now stands as the definitive expression of his thought - a touch here or there, perhaps; a little added emphasis to some principle, an ultimate assertion of his steadfast faith in the creed which both his poetry and his life so nobly exemplifybut the work itself is accomplished, his mission has been fulfilled, his burden has been delivered.

It is impossible to contemplate the life of this man, with a thorough knowledge of his work or even with an imperfect realization of it, without experiencing a feeling of profound and reverential respect. But we are too near him now to get other than an imperfect view of him; his personality is so great that it crowds the narrow field of our vision; to be adequately grasped and appreciated he must be seen in the perspective of at least one hundred years. His figure then will be sharply outlined against the background of history, and the future will see with unshaded eye and in a light softened and tempered by time that of which the present can get but a partial view.

It is a matter of no little significance that here has appeared in American literature a man who has had a burden, in the true sense of the word, to deliver. We have and have had poets of very respectable ability, but none of them has had other than an imaginary burden to deliver. They have sung, it is true, and sweetly, too, oftentimes, but they have not sung a new song. In analyzing their work it is easy to find close parallels in preceding literature; in searching for the source of the singer's inspiration it may be found almost always in his literary acquisitions, and the influence of this or that past master of song may be unerringly detected. In short, if their work were swept away we should lose little that is new-nothing that could not be duplicated. But the work of Walt Whitman cannot be duplicated and it can be traced to no external sourceit springs directly from himself; it is his own, absolutely.

The simplicity of his life as a poet is comparable only to that of Washington as a commander, and his patriotism amounts to a religion. So impressed is he with the present grandeur, so confident is he of the ultimate triumph of democracy as it is organized in America, that he deems all conventional forms utterly inadequate to express the ideas which it suggests, the principles which it involves. Rhyme and rhythm, in the accepted sense, he discards as impracticable; the theme is too great; the mode of expression must be commensurate with the sublimity of the subject, a motive very different, be it remarked, from that which is commonly assigned as the reason for his rejection of established poetical forms - the mere wanton rebelliousness of insufferable egotism.

True to his instinct of democracy, which illuminates every page he has written and which is the great life-giving principle of his poetry, Walt Whitman does not celebrate the great or the exceptional man, neither the mediæval prince nor the antique knight, or the hero of the olden time, but the average man of to-day. He celebrates not only his brain but his hands, not only his soul but also his body. He sings the praises of no individual but of the masses typified in this, to him, superb product, the average man. 
To him his land is a temple, the principles underlying his government are a religion-his great voice fills the temple, but few hear it, for it sometimes occurs that those having ears do not hear.

Never was that old, old saying that prophet is not without honor save in his own country better exemplified than in the case of Walt Whitman. It would be superfluous to attempt to defend him from the ridicule and abuse to which he has been subjected by his countrymen. No defense is necessary, because such ridicule and abuse are the twin offspring of ignorance and stupidity. People who know absolutely nothing of his writing, either prose or verse, who have not read even "O Captain, My Captain," do not hesitate to assail him, to excoriate him, to blackguard him with a vehemence which is pitiful in that it reveals measureless, fathomless depths of ignorance. Others from less unworthy motives have made an outcry on the score of outraged decency, but the one page in all of Walt Whitman's works which may be objected to on this ground is part and parcel of his doctrine - is vital, in fact - and to question the intellectual honesty of the poet on account of it is simply monstrous. [...]

\section{Edward Carpenter. "November Boughs.” The Scottish Art Review 1 (April 1889), 334-335.}

[. . .] After all, November Boughs is just what its title suggests. The full foliage and wealth of summer has gone; but in exchange comes the widening prospect, the faint blue distance, the strangely-quickening odour of dead and dying leaves; the branches are alive with motion - the sough of the vast wind that sweeps over the world - the cosmic lifewhich, however impalpable, breathes through these pages. In one of his pieces in this volume Walt Whitman, apostrophising the Sea, declares that he would gladly surrender the powers of Homer and Shakespeare, if only the Sea would breathe upon his verse 'and leave its odor there.' And in another passage (in the introductory essay) he says-'No one will get at my verses who insists upon viewing them as a literary performance, or attempt at such performance, or as aiming mainly towards art or æstheticism.' It is in this quality of Nature in Whitman's work, transcending Art, yet indeed only possible through the patient study, through the perfection and final surrender of Art, that the secret of Whitman's power lies. The breath of the free wind blows through his pages. Criticism of his imperfections is easy; the secret of his power is difficult to attain.

\section{Other newly discovered reviews:}

Walter Lewin. "November Boughs.” The Academy 35 (February 23, 1889), 127.

"Books of the Week: Walt Whitman Unbosoms Himself About Poetry." New York Herald (December 23, 1888), 7.

Image, Selwyn. "A New Book by Mr. Whitman." Hobby Horse 13 (January 1889), 37-39. 
“Good-Bye My Fancy.” Poet Lore 3 (1891), 644.

"The New Books: Queen Nathalie.-Walt Whitman.-The Young Emperor." Review of Reviews 4 (September 1891), 227.

\section{LEAVES OF GRASS (1891-1892)}

“Leaves of Grass.” Poet Lore 4 (1892), 286-287.

\section{NOTES}

1 Isaac D'Israeli, British man of letters and father of the politician Benjamin Disraeli, first published his popular Curiosities of Literature, consisting of anecdotes, characters, sketches, and observations, literary, critical, and historical in 1791. In the nineteenth century, it was reprinted and expanded multiple times.

2 "Walt Whitman's New Poem," Cincinnati Daily Commercial (December 28, 1859), 2 .

3 In 1822 French physicist Augustin Fresnel invented a light with a concentrated and powerful beam that became common on the seacoasts of North America and Europe. Alexander Smith (1830-1867) was a Scottish poet of the so-called "spasmodic school."

4 In the Revolutionary War, Colonel James Miller at Lundy's Lane said, "We can try" when asked if his regiment could capture a British battery. Robert the Bruce I (1274-1329), King of Scotland, escaped to a cave after defeat in battle. Legend has it that while waiting he watched a spider attempt to build a web in the cave's entrance. Despite falling down many times, the spider continued until the web was completed. Bruce determined to renew his fight and reportedly told his men, "If at first you don't succeed, try try and try again." Saint Vitus is the patron saint of young people, dogs, and dancers. A disease is named after him, Sydenham's Chorea, which can sometimes cause dancing mania.

5 In his next column a week or two later, "Umos" complains that his punning "musecal" was misprinted as "musical."

6 Tattersalls is "Europe's Largest Bloodstock Auctioneers and the world's oldest, dating back to 1766." See http://www.tattersalls.com/.

7 "All that is not prose is verse, and all that is not verse is prose," a line from Le Bourgeois Gentilhomme (1670), a play by Moliére (1622-1673). 
8 At least four Buttermilk Falls exist in New York-one in Buttermilk Glen, in Ithaca, one in LeRoy near Rochester, one in the Catskills, and one near Long Lake in the Adirondack State Park. A razor strop is used to sharpen barber-shop razors.

9 Whitman is called "the New Nebuchadnezzar" in a list of Henry Clapp's bon mots in the New-York Saturday Press (May 26, 1860), 2.

10 Pierre du Terrail, seigneur de Bayard (c. 1474-1524) was a French military hero (often called "the knight without fear or blame"). He fought bravely throughout the Italian wars. He is credited with saving central France from invasion through his defense of Mézières (1521).

11 "Mill" in this context might be a term for a free-for-all or melee, and Heenan was a boxing champion in the U.S. He had lost to John Morrissey in 1858, but was generally accepted as the new U.S. champion after the retirement of Morrissey, and was endorsed by Morrissey. On April 16, 1860, in Farnborough, England, Heenan fought Tom Sayers, the British Champion, in the "World Championship."

12 This seems to be a pun suggesting at once inanities and "Heenanites," with the latter being a reference to the championship boxer John Carmel Heenan. The allusion is topical since Heenan had married Adah Isaacs Menken, an infamous actress associated with a bohemian crowd including Walt Whitman. She married Heenan in September 1859; it became public knowledge in January 1860. In February 1860 Alexander Menken revealed that he had never divorced Adah and she was publicly reviled. Adah published a number of poems in the Sunday Mercury, including "The Autograph on the Soul" in April 1860. According to Allen Lesser, "The Autograph on the Soul" is Menken's first free-verse poem and shows Whitman's influence [Enchanting Rebel (New York: The Beechhurst Press, 1947), 65].

13 "Be off, be gone, you uninitiated!" A misquotation of line 258, Book VI of Virgil's Aeneid, "procul, o procul este, profane."

14 Malaga, Spain, was once a major Moorish city and port, famed for its figs and wine. In 1487 the city fell to Isabella and Ferdinand, the Christian conquerors.

15 Quevredo is a misspelling of the name of the sixteenth-century Spanish poet Francisco de Quevedo.

16 Probably a reference to Hans Memling (c. 1430-1494), a Flemish painter whose name has been known to be misspelled Hemling and Memlinc.

17 Probably a reference to George Sand's novel Consuelo, first published in the periodical La Revue indépendante (1842-1843).

18 Bulwer Lytton, "Night and Love."

19 Alexandre Dumas' novel La Dame aux Camélias (1848) was the basis of Verdi's opera La Traviata (1853). The novel involves a courtesan who becomes part of the fashionable world of Paris. She has the opportunity to escape her debts if she becomes the mistress of Count de Varville, but she chooses instead to escape to the country with Armand Duval, her impoverished lover. In self-sacrificing fashion, she gives up her lover for the sake of his family. They are only reunited in a tragic death scene.

20 "Crash" is a kind of coarse linen often used in towels and known for its roughness.

21 Otto is a fragrant essential oil, and a drachm is one eighth of an ounce. 
22 William Dorrell (1752-1846) was born in England but came to America with the British Army to fight in the Revolutionary War. In 1794 he began preaching. Dorrell was illiterate but he nonetheless memorized long passages of the Bible. He contended that each generation had its own Messiah, that he was the Messiah of his time, and that he and his followers were perfect. Thus they were free to form relationships as they pleased.

23 Heber C. Kimball, a counselor to Brigham Young and a church leader, had fortythree wives. Seventeen wives gave birth to his forty-five sons and twenty daughters.

24 The Iliad 6.352-353: "His mind is not firmly grounded, nor will it ever be; he will reap the fruits of this."

25 According to the Oxford Dictionary of National Biography, John Hollingshead was a prolific London journalist who often wrote on urban working-class life, including a number of articles for Dickens's Household Words.

26 J. T. S. Lidstone, who wrote many versions of "Londoniad."

27 Guano is the excrement of sea birds, used as a fertilizer. It was a major European import from the mid-century to the 1870s.

28 Rotherhithe was a famous shipbuilding area and the major whaling base in London until the trade declined in the 1840s. A coal-whipper is a person employed in moving coal. This often involved raising coal out of a ship's hold through the use of a pulley.

29 Samuel Johnson was not impressed with Thomas Percy's collection of Ancient English and Scottish Poems. Johnson observed in conversation that "he could rhyme as well, and as elegantly, in common narrative and conversation." See fohnsonian Miscellanies, ed. George Birkbeck Hill (Oxford Clarendon Press, 1897) 1:314.

30 A spicy stew (originally from Spain or Portugal).

31 George Wither (1588-1667) was a British poet who dedicated a book of satires to himself. Martin Farquhar Tupper (1810-1889) was a popular British poet who wrote religious and philosophical free verse.

32 Possibly a reference to "muscular Christianity," a movement to counter the traditional elevation of soul over body by emphasizing manly athleticism. It first appeared in Britain under this name in the late 1850s and quickly spread to the United States.

33 The Persian poet Shams-ud-din Muhammad (c.1300-1388) took the pen name of Hāfiz.

34 William Hepworth Dixon (1821-1879) was a British journalist and editor of the Athenaeum from 1853-1869. He traveled to the U.S. in 1866 and published New America (1867).

35 Brighton has a beach whose medium-sized pebbles, called shingles, make walking difficult.

36 In an 1849 essay, "The Art-Work of the Future," Wagner described a vision of opera as Gesamtkunstwerk, or "total artwork," in which music, song, dance, poetry, visual arts, and stagecraft came together. 
37 Mentioned several times in the Bible, the Balm of Gilead refers to a healing compound made from a plant that grew in the area of Gilead. Apollo is the Greek and Roman god of music and poetry (as well as medicine and healing). In Greek mythology, Hippocrene is a fountain on Mt. Helicon whose water when drunk led to poetic inspiration. Parnassus and Helicon are mountains in Greece mentioned in mythology.

38 Well-known poets recognized for the strong national character of their work.

39 A reference to Shakespeare.

40 "Bene quodcumque est" is "[It is] well, whatever it is." That is, "Say nice things about everything."

41 Alexander Pope, An Essay on Man, Epistle IV, lines 49-50.

42 Shakespeare, Troilus and Cressida, Act I, Scene 3, lines 109-110.

43 W. M. Rossetti's comment on Whitman in his introduction to Poems by Walt Whitman, 3.

44 Giuseppe Mazzini (1805-1872) was an Italian patriot, philosopher, and politician. Mazzini helped to bring about the modern Italian state, which replaced the system that had existed until the nineteenth century of several separate states dominated by foreign powers. He also helped define the modern European movement for popular Democracy in a Republican State. Giuseppe Garibaldi (1807-1882) was an Italian patriot and soldier of the Risorgimento. He personally led many of the military campaigns that brought about the formation of a unified Italy. He was called the "Hero of the Two Worlds," in tribute to his military expeditions in South America and Europe.

45 Auguste Comte (1798-1857) was a French positivist thinker who came up with the term sociology to name the new science made by Saint-Simon. Comte saw himself as founder and prophet of a new "religion of humanity."

46 Thomas Henry Huxley (1825-1895), an English biologist, was a forceful proponent of Charles Darwin's theory of evolution and a key leader in the development of scientific education in Britain. John Tyndall (1820-1893) was an Irish natural philosopher who, along with Darwin and Huxley, helped spread popular knowledge of physical science and helped make modern science widely accepted.

47 In "The Hero as Poet" in On Heroes, Hero-Worship, and the Heroic in History (New York: Frederick A. Stokes \& Brother, 1888), 127.

48 1 John 2:20.

49 Isaiah 63:1.

50 Minnie Maddern Fiske (1865-1932), often billed merely as “Mrs. Fiske," was a leading American actress of the late-nineteenth and early-twentieth century. Tammany Hall is famous as the Democratic machine in New York City politics. In the 1870s, William Tweed, a New York politician, became implicated in a scandal involving the disappearance of about 200 million taxpayers' dollars. In a series of cartoons about the "Tammany Ring," Thomas Nast drew attention to the group of politicians involved in the scandal. Tweed's career was ruined, and he served time in jail.

51 Carlyle, Latter-Day Pamphlets at http://www.fullbooks.com/Latter-Day-Pamphlets4. htm.

52 Tetanic is the motion characteristic of the disease tetanus. 
53 Possibly a misquotation of "Poeta nascitur, non fit," meaning "the poet is born, not made."

54 These lines are slightly misquoted from Wordsworth, "Elegiac Stanzas Suggested by a Picture of Peele Castle, in a Storm, painted by Sir George Beaumont.”

55 "Are not Abana and Pharpar, rivers of Damascus, better than all the waters of Israel? may I not wash in them, and be clean? So he turned and went away in a rage" (2 Kings $5: 12)$.

56 "But wisdom is justified of all her children" (Luke 7:35).

57 "Can Any Good Thing Come out of Nazareth?" (John 1:46). Clear Grits were reformers in the province of Upper Canada, a British colony that is now Ontario, Canada. Their support was concentrated among southwestern Ontario farmers, who were frustrated and disillusioned by the 1849 Reform government of Robert Baldwin and Louis-Hippolyte Lafontaine's lack of radicalism. The Clear Grits advocated universal male suffrage, representation by population, democratic institutions, and free trade with the United States. The name derives from a quote by party member David Christie who describe the movement as "all sand and no dirt; clear grit all the way through," a reference to the type of sand preferred in the preparation of masonry. "Clear Grit" was a complimentary term meaning tenacious or dedicated. "And his feet like unto fine brass, as if they burned in a furnace; and his voice as the sound of many waters" (Revelation $1: 15)$.

58 Possibly a reference to Book 11 of the Odyssey.

59 The "seven cities" refer to Chios, Athens, Rhodes, Colophon, Argos, Smyrna, and Salamis. They can easily be remembered through the mnemonic "carcass" (the first letter of each city spells the word). The lines have been attributed to several writers, including Thomas Heywood (died 1649), who wrote: "Seven cities warred for Homer being dead; / Who living had no roofe to shrowd his head." Thomas Seward (1708-1790) is accredited the lines: "Seven wealthy towns contend for Homer dead / Through which the living Homer begged his bread."

60 See endnote \#36 about Wagner's “The Art-Work of the Future.”

61 The Apollo Belvedere (not Belvidere, as in the original) is a marble statue that is a copy of a bronze original done by the Greek sculptor Leochares.

62 These lines are probably based on or refer to "The Cloud of Unknowing" (nubes ignorandi) written by an anonymous fourteenth-century English mystic.

63 Misquoted from Richard Lovelace, "To Althea from Prison."

64 Gustave Doré (1832-1883) was a well-known French artist, engraver, and illustrator. He illustrated works by Rabelais, Balzac, Dante, Lord Byron, Edgar Allan Poe, and others.

65 Milton, "Samson Agonistes," 1279.

66 John Keats, Hyperion, Book II.

67 This is from Fragments from Pindar (1844), 513. 
68 Ralph Waldo Emerson's rendition of a quote he attributed to Pons Capdueil, a medieval French troubadour. See $A$ Concordance of the Collected Essays of Ralph Waldo Emerson, compiled by Eugene F. Irey, http://www.concordlibrary.org/scollect/EmersonConcordance/index.htm.

69 Milton, Paradise Lost, Book I, line 540.

70 Westminster Review 74 n.s. 18 (October 1860), 590.

71 Moncure Conway, Dial (August 1860), 517-519.

72 “Marco Bozzaris," poem about the fighter for Greek independence by the American poet Fitz-Greene Halleck; "Hohenlinden," a poem about a battle in the Napoleonic wars by Thomas Campbell, a Scottish poet.

73 Taliesin (c.534-c.599) was a Welsh-speaking poet.

74 "Shame upon him who thinks evil of it."

75 The copy we have transcribed here is damaged, and no better copy has been located.

76 This is actually on p. 46.

77 Richard Bentley, Cometh Up as a Flower: An Autobiography (New Burlington Street, 1867), 40 .

78 Edmund Clarence Stedman, "Walt Whitman," Scribner's Monthly 21 (1880), 4765.

792 Kings 2:23.

80 Possibly a blunder for "Rosa Matilda," the pen name of Charlotte Dacre, writer of popular sensational novels. The Rosa Matilda "school" included writers who depicted violence and frank sexuality, rather than the authors of maudlin sentimentality to which this reviewer alludes.

81 A correspondent for the Providence fournal gives this account of the origin of the term "Hoosier": "Throughout all the early Western settlements were men who rejoiced in their physical strength, and on numerous occasions, at log-rollings and house-raisings, demonstrated this to their entire satisfaction. They were styled by their fellow citizens, 'hushers,' from their primary capacity to still their opponents. It was a common term for a bully throughout the West. The boatmen of Indiana were formerly as rude and as primitive a set as could well belong to a civilized country, and they were often in the habit of displaying their pugilistic accomplishments" (quoted in Dictionary of Americanisms [1848]). Interestingly, Whitman once described Lincoln as follows: "I think well of the President. He has a face like a hoosier Michael Angelo, so awful ugly it becomes beautiful, with its strange mouth, its deep cut, criss-cross lines, and its doughnut complexion." See Correspondence, 1:82.

82 William Kingdon Clifford's “Cosmic Emotion” (The Nineteenth Century 2, no. 8 [October 1877]: 411-429).

83 François de Salignac de la Mothe Fénelon (1651-1715) was a French theologian and writer and the archbishop of Cambrai.

84 Bunthorne is a reference to a Gilbert and Sullivan opera titled "Patience, or Bunthorne's Bride" (1881). 
85 Professor William Kingdon Clifford. The source of this quotation is unidentified.

86 On June 3, 1882, The Critic expressed its disapproval of the threat to suppress Leaves of Grass in a piece titled "The Massachusetts Dogberry." (Dogberry is a reference to a night constable in Shakespeare's Much Ado About Nothing.) Then after Whitman broke with his Boston publisher James Osgood and reissued Leaves with a Philadelphia publisher, The Critic complained that "Rees Welsh \& Co., do not realize the importance of their undertaking, and have not so much the courage of their opinions as an eye to the profits of gratuitous advertising." See The Critic 45 (September 23, 1882), 254.

87 An urchin or homeless boy.

88 Anthony Comstock (1844-1915) helped found the New York Society for the Suppression of Vice (1873) and became notorious for his crusades against art and literature, including Leaves of Grass, that he considered obscene.

89 George Chainey published This World in Boston in the early 1880s. Chainey became involved in opposing the suppression of Leaves of Grass and discussed the matter on July 1, July 6, and November 4, 1882 .

90 Mrs. Grundy, a term for an extremely conventional or priggish person, refers to a character in the play Speed the Plough by British playwright Thomas Morton (17641838).

91 Josephine Elizabeth Butler (1828-1906) was a feminist whose causes included the welfare of prostitutes.

92 This quotation is from a collection of conversations between Goethe and Johann Peter Eckermann. "Der Tod ist doch etwas so Seltsames, daß man ihn, unerachtet aller Erfahrung, bei einem uns teuren Gegenstande nicht für möglich hält und er immer als etwas Unglaubliches und Unerwartetes eintritt. Er ist gewissermaßen eine Unmöglichkeit, die plötzlich zurWirklichkeit wird. Und dieser Übergang aus einer uns bekannten Existenz in eine andere, von der wir auch gar nichts wissen, ist etwas so Gewaltsames, daß es für die Zurückbleibenden nicht ohne die tiefste Erschütterung abgeht." Gespräche mit Goethe, Leipzig, Band 1 und 2: 1836, Band 3: 1848, S. 743.

93 Ernest Rhys, "Introduction" to Leaves of Grass: The Poems of Walt Whitman (London: Walter Scott, 1886), xxxv.

94 Probably a mistaken reference to "The Dalliance of the Eagles." 